\title{
FERNANDO KAMEOKA
}

Reciclagem de resíduos eletroeletrônicos: um estudo cinético da lixiviação ácida de ferro de placas de circuito impresso de microcomputadores 


\section{FERNANDO KAMEOKA}

Reciclagem de resíduos eletroeletrônicos: um estudo cinético da lixiviação ácida de ferro de placas de circuito impresso de microcomputadores

Dissertação apresentada à Escola Politécnica da Universidade de São Paulo para obtenção do título de Mestre em Ciências

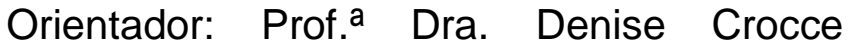
Romano Espinosa

São Paulo 


\section{FERNANDO KAMEOKA}

Reciclagem de resíduos eletroeletrônicos: um estudo cinético da lixiviação ácida de ferro de placas de circuito impresso de microcomputadores

Dissertação apresentada à Escola Politécnica da Universidade de São Paulo para obtenção do título de Mestre em Ciências

Área de Concentração: Engenharia Química

Orientador: Prof. ${ }^{a}$ Dra. Denise Crocce Romano Espinosa

São Paulo 
Este exemplar foi revisado e corrigido em relação à versão original, sob responsabilidade única do autor e com a anuência de seu orientador.

São Paulo, 22 de Setembro de 2015.

Assinatura do autor:

Assinatura do orientador:

\section{Catalogação-na-publicação}

\section{Kameoka, Fernando}

Reciclagem de resíduos eletroeletrônicos: um estudo cinético da lixiviação ácida de ferro de placas de circuito impresso de microcomputadores / F. Kameoka -- versão corr. -- São Paulo, 2015.

$135 \mathrm{p}$.

Dissertação (Mestrado) - Escola Politécnica da Universidade de São Paulo. Departamento de Engenharia Química.

1.Hidrometalurgia 2.Lixiviação 3.Reciclagem 4.Cinética 5.Resíduo eletroeletrônico I.Universidade de São Paulo. Escola Politécnica. Departamento de Engenharia Química II.t. 
Dedico este trabalho a meus familiares e aos meus amigos. 


\section{AGRADECIMENTOS}

À minha orientadora Prof. a Dra. Denise Crocce Romano Espinosa pelo direcionamento, pela dedicação e toda a paciência dispensada ao longo do desenvolvimento deste trabalho.

À amiga e conselheira Viviane Tavares de Moraes por todo o apoio e suporte na elaboração deste trabalho, e sem a qual este não teria sido realizado.

Ao meu co-orientador Prof. Dr. Jorge Alberto Soares Tenório pelo incentivo, companheirismo e pelas palavras de sabedoria nos momentos difíceis.

À minha namorada Renata pela paciência e muito carinho nas inúmeras madrugadas e nos finais de semanas dedicados a este trabalho.

Aos amigos Ana Carolina Dalsin, Mônica Jimenez e Franco Ramunno pelo suporte nas análises e discussões que estão presentes neste trabalho.

Ao velho amigo Hugo Hashimoto pelas trocas de experiências e pelos momentos de descontração nas horas em que nada poderia dar certo.

A todos os amigos do Departamento de Engenharia Metalúrgica e de Materiais (PMT) e do Departamento de Engenharia Química (PQI), que tornaram cada dia de trabalho mais prazeroso e onde encontrei palavras de incentivo, carinho e amparo, e sem os quais nada disto faria sentido.

À minha família pela compreensão, incentivo e apoio durante todo o período de elaboração deste trabalho, e em especial às minhas duas sobrinhas Amanda e Gabriela, motivos das minhas maiores alegrias; à minha afilhada Maria Luiza e ao João Pedro.

A todos os funcionários administrativos e técnicos do PMT e do PQI.

À Escola Politécnica e à Universidade de São Paulo.

Ao Conselho Nacional de Desenvolvimento Científico e Tecnológico CNPq. 
"O mais alto de nós não é mais que um conhecedor mais próximo do oco e do incerto de tudo."

Fernando Pessoa 


\section{RESUMO}

O aumento no consumo mundial de novos aparelhos eletroeletrônicos aliado à redução no tempo de vida útil destes equipamentos tem como principal consequência ao meio ambiente a geração de resíduos. No Brasil, com a instituição da Política Nacional de Resíduos Sólidos, criou-se a obrigatoriedade legal da responsabilidade dos fabricantes pela logística reversa dos equipamentos eletroeletrônicos, incentivando pesquisas para o desenvolvimento dos métodos de reciclagem e tratamento dos materiais descartados. O processo de lixiviação foi avaliado como alternativa à etapa de separação magnética presente nas atuais rotas hidrometalúrgicas para recuperação de metais valiosos de placas de circuito impresso. Para avaliar a composição das placas, foi realizado ensaio de dissolução em água régia. As amostras foram moídas e submetidas a ensaios de lixiviação com ácido sulfúrico nas concentrações de 1 e $2 \mathrm{~mol} / \mathrm{L}$, às temperaturas de $75^{\circ} \mathrm{C}, 85^{\circ} \mathrm{C}$ e $95^{\circ} \mathrm{C}$, durante 24 horas. Com ácido sulfúrico $2 \mathrm{~mol} / \mathrm{L}$ a $95^{\circ} \mathrm{C}$, o tempo necessário para se obter $100 \%$ de extração do ferro foi de 2 horas. Nestas condições, não foi detectada a presença de cobre dissolvido. A cinética da reação é controlada por reação química

e obedece a equação $k \cdot t=1-\sqrt[3]{\left(1-X_{B}\right)}$. A energia de ativação aparente do processo equivale a $90 \mathrm{~kJ} / \mathrm{mol}$.

Palavras-chave: Resíduo eletroeletrônico. Reciclagem. Lixiviação. Hidrometalurgia. Separação magnética. Cinética. 


\begin{abstract}
The increase in world consumption of new electronic equipment along with the reduction of its lifespan has brought an environmental issue due to waste generation. In Brazil, the National Solid Waste Policy establishes that manufacturers should respond for the reverse logistics of consumer electronics devices. This policy encouraged research to the development of methods of treatment and recycling of discarded materials. Acid leaching was analyzed as an alternative to the magnetic separation process widely used in hydrometallurgical routes for precious metals recovery from PCBs. Aqua regia was used to dissolve PCBs and thus characterize samples. The samples were milled and leached with sulfuric acid 1 and $2 \mathrm{~mol} / \mathrm{L}$, at temperatures of $75^{\circ} \mathrm{C}, 85^{\circ} \mathrm{C}$ and $95^{\circ} \mathrm{C}$, during 24 hours. With sulfuric acid $2 \mathrm{~mol} / \mathrm{L}$ at $95^{\circ} \mathrm{C}$, the necessary time for $100 \%$ iron extraction was 2 hours. Under these conditions, no copper was detected. Reaction kinetics is controlled by chemical reaction and follows the expression k.t $=1-\sqrt[3]{\left(1-X_{B}\right)}$. Apparent activation energy equals $90 \mathrm{~kJ} / \mathrm{mol}$.
\end{abstract}

Keywords: Waste electroelectronic. Recycling. Leaching. Hydrometallurgy. Magnetic separation. Kinetics. 


\section{SUMÁRIO}

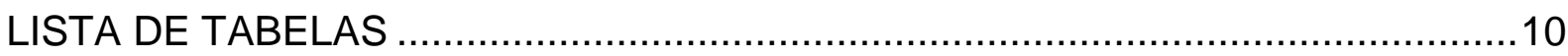

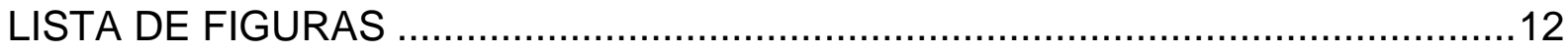

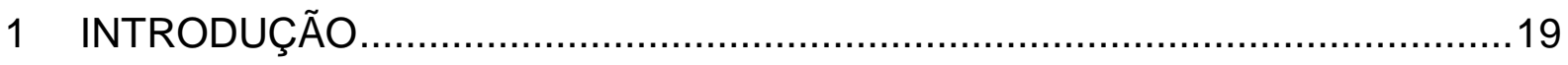

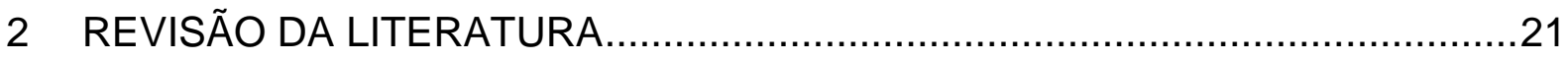

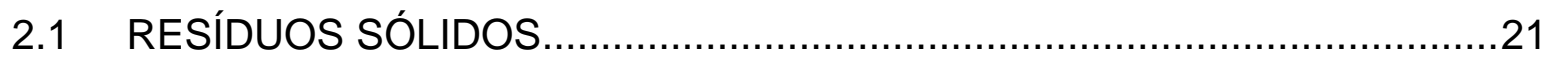

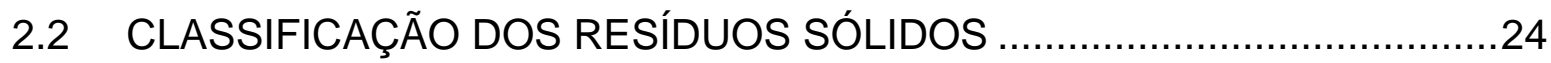

2.3 RESÍDUOS DE EQUIPAMENTOS ELETROELETRÔNICOS ......................26

2.3.1 Volume de resíduos eletroeletrônicos................................................27

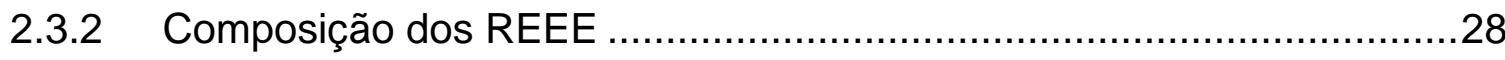

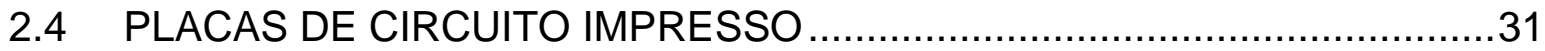

2.4.1 Composição das placas de circuito impresso ........................................33

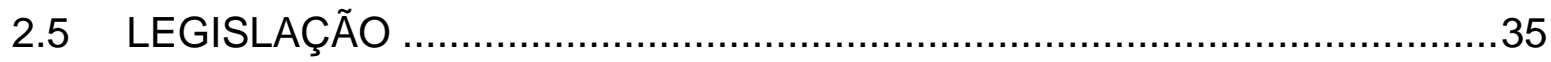

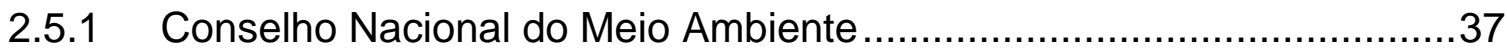

2.5.2 Política Nacional de Resíduos Sólidos ...............................................38

2.6 TRATAMENTO DOS RESÍDUOS DE EQUIPAMENTOS

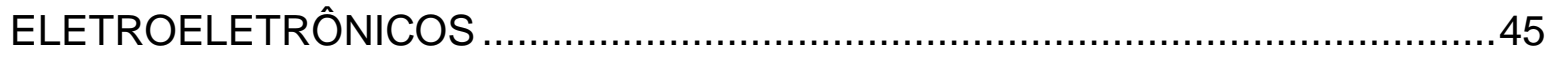

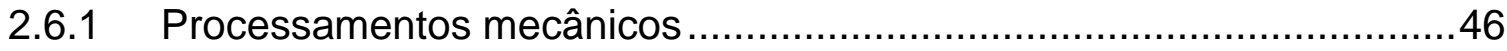

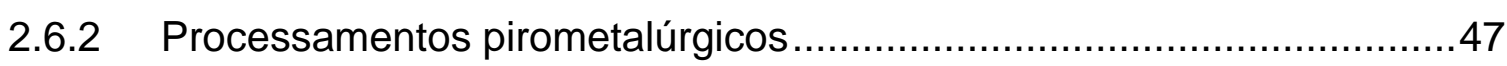

2.6.3 Processamentos biohidrometalúrgicos ............................................. 49

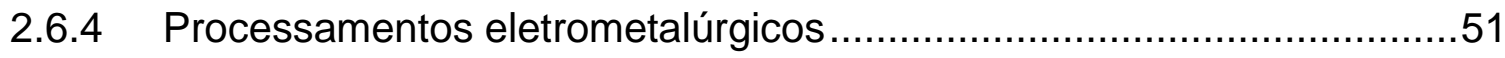

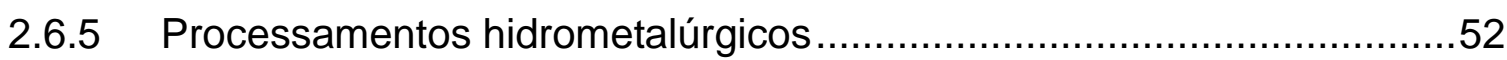

2.7 A ROTA HIDROMETALÚRGICA PARA TRATAMENTO DE REEE.............53

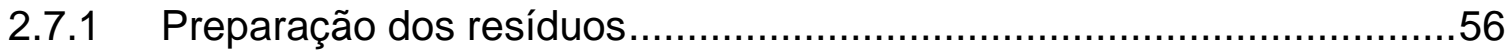

2.7.1.1 Desmantelamento manual: um pré-processamento ..........................57

2.7.1.2 Cominuição através da moagem dos REEE ...................................58

2.7.1.3 Peneiramento e classificação .............................................................59 


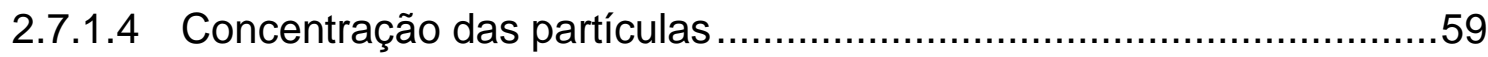

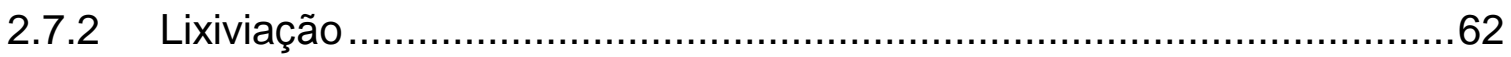

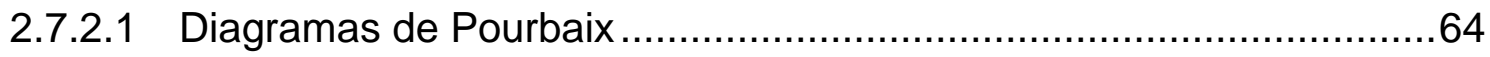

2.7.3 Ensaios de digestão em água-régia ....................................................66

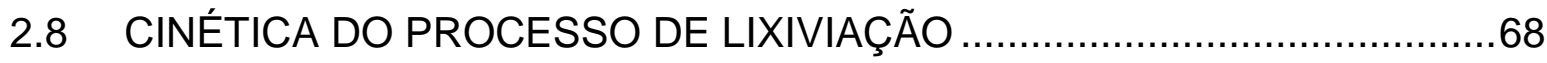

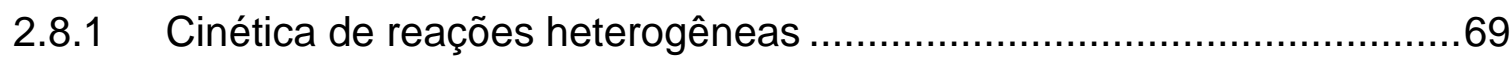

2.8.2 Modelos cinéticos para a reação de lixiviação .......................................70

2.8.3 Etapa controladora da reação de lixiviação ............................................71

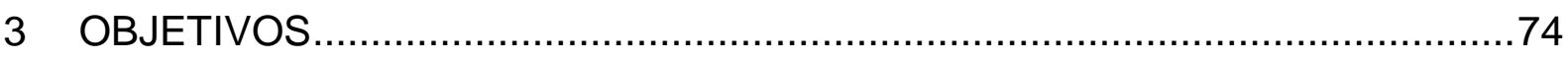

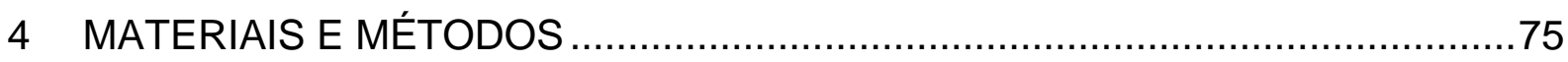

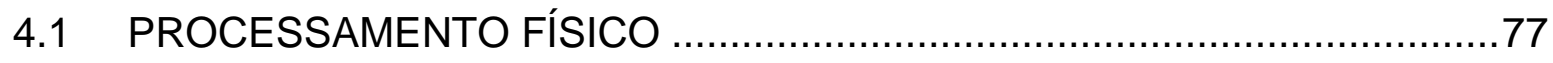

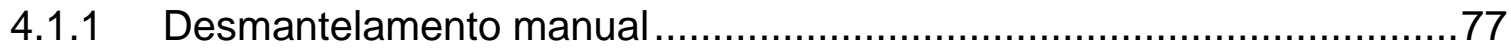

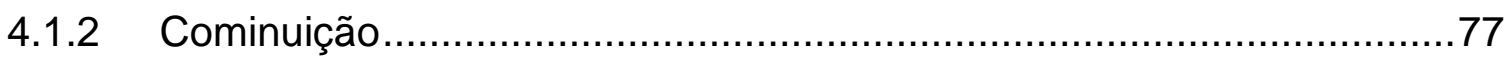

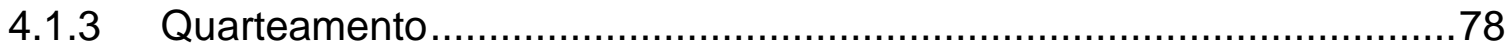

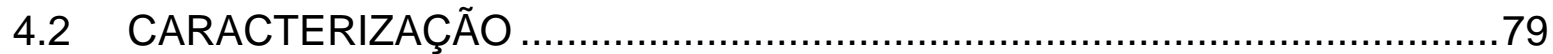

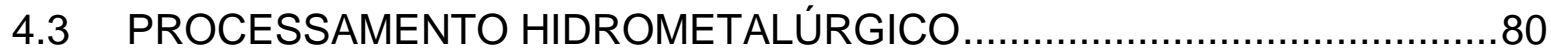

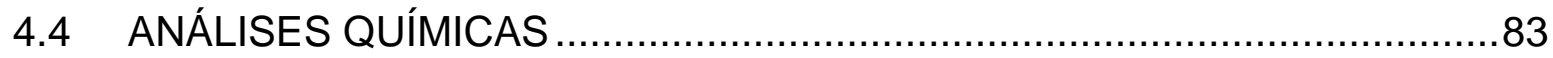

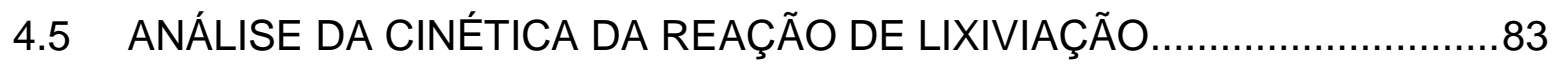

4.5.1 Determinação da etapa controladora da reação de lixiviação do ferro ..84

4.5.2 Equações lineares dos mecanismos controladores das reações

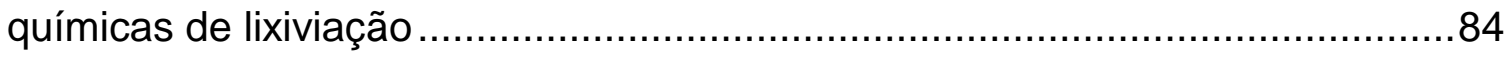

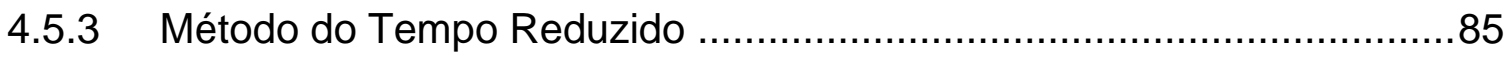

4.5.4 Cálculo da energia de ativação..........................................................

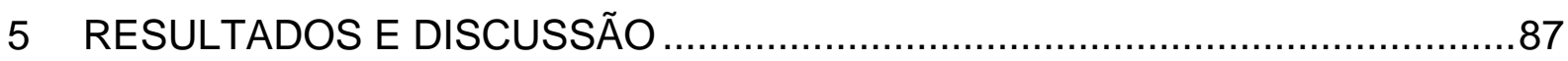

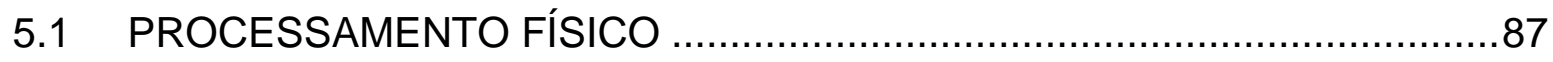

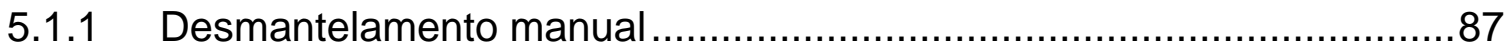

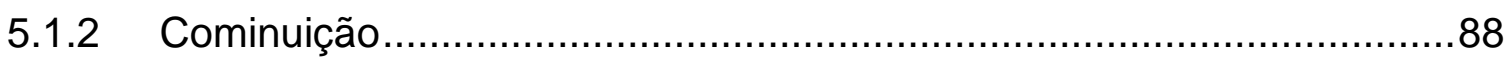

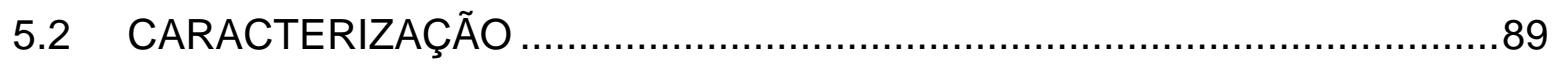


5.3 ENSAIOS DE LIXIVIAÇÃO

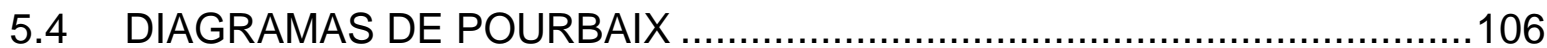

5.5 ANÁLISE DA CINÉTICA DA REAÇÃO DE LIXIVIAÇÃO..........................108

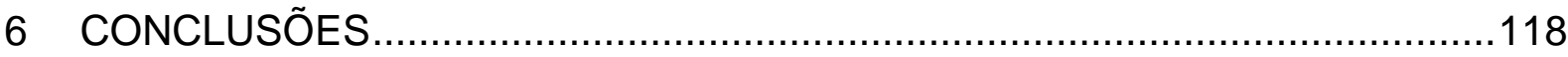

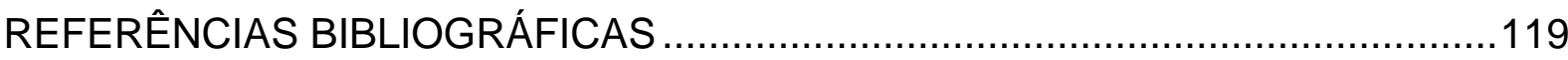




\section{LISTA DE TABELAS}

Tabela 1 - As categorias de Equipamentos Eletroeletrônicos e alguns exemplos (MDIC, 2013).

Tabela 2 - Relação de países com as suas rendas per capita e a relação com o volume de geração de REEE (INVENTTA, CIA WORLDFACTBOOK e UNITED NATIONS UNIVERSITY, 2013).

Tabela 3 - Relação dos elementos que compõem os resíduos de equipamentos eletroeletrônicos e respectivos percentuais em massa (WIDMER et al., 2005). 29

Tabela 4 - Relação dos componentes presentes nos REEE que oferecem riscos à saúde humana seguidos de descrição (CUI et al., 2003; TSYDENOVA et al., 2011).

Tabela 5 - Percentual de massa dos componentes de computadores pessoais de mesa e portáteis (XAVIER et al., 2012).

Tabela 6 - Destino do Resíduo Sólido Urbano em porcentagem de peso (CEMPRE, 2004).

Tabela 7 - Levantamento das situações das Políticas Estaduais de Resíduos Sólidos, leis que as instituem e decretos que as regulamentam (USHIZIMA, MARINS e MUNIZ JR., 2014; adaptação do autor).

Tabela 8 - Leis Estaduais que abordam o tratamento e a gestão dos REEE (USHIZIMA, MARINS e MUNIZ JR., 2014; adaptação do autor).

Tabela 9 - Variáveis ambientais que afetam a performance dos processos biohidrometalúrgicos (ROSALES, GUERRERO e SÁEZ, 2001, em tradução livre; ROSARIO et al., 2014, adaptação do autor). .50

Tabela 10 - Classificação dos materiais quanto às suas características de susceptibilidade magnética (SAMPAIO, FRANÇA e LUZ, 2007).

Tabela 11 - Massa das amostras utilizadas nas lixiviações e respectivos volumes de ácido.

Tabela 12 - Resultados dos ensaios de extração de metais em ácido sulfúrico 1mol/L em 24 horas a diferentes temperaturas, em porcentagem em massa.

Tabela 13 - Quadro das condições de extração dos metais alumínio, cobre, ferro, níquel e zinco presentes nas amostras, analisados individualmente nos ensaio com ácido sulfúrico à concentração de $1 \mathrm{~mol} / \mathrm{L}$. 
Tabela 14 - Resultados dos ensaios de extração de metais em ácido sulfúrico $2 \mathrm{~mol} / \mathrm{L}$ em 24 horas a diferentes temperaturas, em porcentagens em massa.

Tabela 15 - Quadro das condições de extração dos metais alumínio, cobre, ferro, níquel e zinco presentes nas amostras, analisados individualmente nos ensaios com ácido sulfúrico à concentração de $2 \mathrm{~mol} / \mathrm{L}$. .99

Tabela 16 - Resultados dos cálculos da somatória dos quadrados das diferenças para determinação do mecanismo de controle cinético da reação de lixiviação nos ensaios H1M75C, H1M85C e H1M95C. 110

Tabela 17 - Resultados dos cálculos da SQD para os ensaios H2M75C, H2M85C e H2M95C 


\section{LISTA DE FIGURAS}

Figura 1 - Aumentos na geração de Resíduos Sólidos Urbanos e na geração de RSU per capita entre os anos de 2012 e 2013 no Brasil (ABRELPE, 2014; IBGE, 2014). 22

Figura 2 - Aumentos na quantidade de Resíduos Sólidos Urbanos coletados e na coleta de RSU per capita entre os anos de 2012 e 2013 no Brasil (ABRELPE, 2014; IBGE, 2014).

Figura 3 - Fluxograma para caracterização e classificação do resíduo sólido segundo norma ABNT-NBR 10.004:2004 (ABNT, 2004). 25

Figura 4 - Imagens com exemplos de Placas de Circuito Impresso (Google Imagens, acesso em 11 de maio de 2015; adaptação do autor). 32

Figura 5 - Relação dos elementos que compõem uma placa de circuito impresso típica com respectivos valores percentuais em massa (LUDA, 2011; adaptação do autor).

Figura 6 - Imagens da cidade de Guiyu, na província chinesa de Guangdong, onde é comum ver pessoas - adultos e crianças - conviverem com o REEE (AFONSO, 2010; adaptação do autor).

Figura 7 - Imagens da cidade de Guiyu, com pessoas trabalhando em condições precárias de higiene e segurança (AFONSO, 2010; adaptação do autor).

Figura 8 - Esquema geral da etapa de processamento mecânico (LACOR, 2014)...47

Figura 9 - Esquema genérico de um típico processo hidrometalúrgico (CIMINELLI, 2007).

Figura 10 - O desmantelamento manual de placas de circuito impresso traz diversos benefícios ao processo de tratamento dos REEE (CEDIR, 2011).

Figura 11 - Esquema simplificado do Diagrama de Pourbaix para metais (POURBAIX,1966; JACKSON, 1986).

Figura 12 - Diagrama de equilíbrio potencial $(\mathbf{E h}) / \mathrm{pH}$ para o sistema ferro-água à temperatura de 25ㄷ $\mathrm{C}$ (POURBAIX e ZOUBOV, 1963; adaptação do autor). 66

Figura 13 - Comportamento das partículas nas reações heterogêneas em que o tamanho da partícula permanece inalterado após o término da reação devido à formação de uma camada de passivação (LEVENSPIEL, 1972; adaptação do autor). 
Figura 14 - Comportamento das partículas nas reações heterogêneas em que o tamanho das partículas reduz de tamanho ao longo da reação devido à inexistência de uma camada de passivação (LEVENSPIEL, 1972; adaptação do autor). .70

Figura 15 - Representação das concentrações de reagentes e produtos para a reação $\mathrm{A}(\mathrm{g})+\mathrm{bB}(\mathrm{s}) \rightarrow$ produtos sólidos, para partícula de tamanho constante (LEVENSPIEL, 1972; adaptação do autor).

Figura 16 - Vista superior da placa-mãe de computador pessoal de mesa, sem os componentes acessórios à placa.

Figura 17 - Diagrama com as principais etapas do processo (apenas os processos em destaque foram realizados neste trabalho).

Figura 18 - Detalhe do interior do moinho de facas mostrando as lâminas e a grelha utilizadas neste trabalho. .78

Figura 19 - Imagem de quarteador tipo Jones utilizado no preparo das amostras....79

Figura 20 - Diagrama esquemático do sistema usado no processo de lixiviação ácida (SILVAS, 2014; CALDAS et al., 2015).

Figura 21 - Esquema do balão de fundo chato e cinco bocas utilizado no processo de lixiviação ácida. No detalhe à esquerda, o termômetro mergulhado na solução.

Figura 22 - Componentes que puderam ser removidos manualmente das placas-mãe sem o uso de ferramentas específicas, tais como dissipadores de calor, ventiladores, processadores, placas de memória, fios e cabos elétricos.

Figura 23 - Licor com coloração esverdeada produto da digestão em água régia das placas-mãe.

Figura 24 - Resultados da análise química por ICP-OES do licor resultante da digestão em água régia para caracterização das amostras de placas-mãe, mostrando os percentuais dos principais elementos metálicos encontrados na amostra (CORREA, 2015).

Figura 25 - Resultados da lixiviação do ensaio H1M75C........................................93

Figura 26 - Resultados da lixiviação do ensaio H1M85C.......................................93

Figura 27 - Resultados da lixiviação do ensaio H1M95C. ........................................94

Figura 28 - Resultados da lixiviação do ensaio H2M75C. ......................................97

Figura 29 - Resultados da lixiviação do ensaio H2M85C . ......................................97

Figura 30 - Resultados da lixiviação do ensaio H2M95C........................................98 
Figura 31 - Resultados da lixiviação do alumínio. 100

Figura 32 - Resultados da lixiviação do cobre. 101

Figura 33 - Resultados da lixiviação do ferro. 102

Figura 34 - Resultados da lixiviação do níquel. 103

Figura 35 - Resultados da lixiviação do zinco. 104

Figura 36 - Comparativo da extração do ferro e do cobre a 95ㄷ 105

Figura 37 - Diagrama de Pourbaix para o ferro em meio aquoso para a temperatura de $75^{\circ} \mathrm{C}$. .106

Figura 38 - Diagrama de Pourbaix para o ferro em meio aquoso para a temperatura de $85^{\circ} \mathrm{C}$.

Figura 39 - Diagrama de Pourbaix para o ferro em meio aquoso para a temperatura de $95^{\circ} \mathrm{C}$. 107

Figura 40 - Resultados das aplicações do Método do Tempo Reduzido para os valores de extração do ferro dos ensaios realizados com ácido sulfúrico $1 \mathrm{~mol} / \mathrm{L}$, objetivando a identificação do mecanismo controlador da cinética das reações de lixiviação. .....109

Figura 41 - Valores de $\mathrm{R}^{2}$ para os mecanismos de controle cinético por reação química para os ensaios realizados com ácido sulfúrico $1 \mathrm{~mol} / \mathrm{L}$.

Figura 42 - Valores de $\mathrm{R}^{2}$ para os mecanismos de controle cinético por difusão pela camada limite para os ensaios realizados com ácido sulfúrico $1 \mathrm{~mol} / \mathrm{L}$.

Figura 43 - Curva de -Ink pelo inverso da temperatura para determinação da energia de ativação aparente do controle por reação química dos ensaios com ácido sulfúrico $1 \mathrm{~mol} / \mathrm{L}$.

Figura 44 - Curva de -Ink pelo inverso da temperatura para determinação da energia de ativação aparente do controle por difusão pela camada limite dos ensaios com ácido sulfúrico $1 \mathrm{~mol} / \mathrm{L}$

Figura 45 - Resultados do Método do Tempo Reduzido para os valores de extração de ferro dos ensaios com ácido $2 \mathrm{~mol} / \mathrm{L}$

Figura 46 - Valores de $\mathrm{R}^{2}$ para o controle por reação química para os ensaios com ácido $2 \mathrm{~mol} / \mathrm{L}$.

Figura 47 - Valores de $\mathrm{R}^{2}$ para o controle por difusão pela camada de cinzas para os ensaios com ácido $2 \mathrm{~mol} / \mathrm{L}$. 
Figura 48 - Valores de $R^{2}$ para o controle por difusão pela camada limite para os ensaios com ácido $2 \mathrm{~mol} / \mathrm{L}$.

Figura 49 - Curva de -Ink pelo inverso da temperatura para determinação da energia de ativação aparente do controle por reação química dos ensaios com ácido $2 \mathrm{~mol} / \mathrm{L}$.

Figura 50 - Curva de -Ink pelo inverso da temperatura para determinação da energia de ativação aparente do controle por difusão pela camada de cinzas dos ensaios com ácido $2 \mathrm{~mol} / \mathrm{L}$ 116

Figura 51 - Curva de -Ink pelo inverso da temperatura para determinação da energia de ativação aparente do controle por difusão pela camada limite dos ensaios com ácido $2 \mathrm{~mol} / \mathrm{L}$. 


\section{LISTA DE ABREVIATURAS E SIGLAS}

ABDI

ABNT

Abrelpe

CEDIR

CFC

$\mathrm{CNPq}$

Cempre

Conama

HCFC

HFC

IBGE

ICP-OES

IEE-USP

IPEA

IPT

LACOR

LCA

LME

MCT

MDIC

MMA

MTR
Agência Brasileira de Desenvolvimento Industrial

Associação Brasileira de Normas Técnicas

Associação Brasileira de Empresas de Limpeza Pública e Resíduos Especiais

Centro de Descarte e Reuso de Resíduos de Informática

Clorofluorcarbono

Conselho Nacional de Desenvolvimento Científico e Tecnológico

Compromisso Empresarial para a Reciclagem

Conselho Nacional do Meio Ambiente

Hidroclorofluorcarboneto

Hidrofluorcarbono

Instituto Brasileiro de Geografia e Estatística

Espectrometria de emissão óptica com plasma acoplado indutivamente

Instituto de Energia e Ambiente da Universidade de São Paulo

Instituto de Pesquisa Econômica Aplicada

Instituto de Pesquisas Tecnológicas

Laboratório de Corrosão, Proteção e Reciclagem de Materiais da UFRGS

Life Cycle Assessment ou Análise do Ciclo de Vida

London Metals Exchange ou Bolsa de Metais de Londres

Ministério da Ciência e Tecnologia

Ministério do Desenvolvimento, Indústria e Comércio Exterior

Ministério do Meio Ambiente

Método do Tempo Reduzido 


\begin{tabular}{|c|c|}
\hline NBR & Norma Brasileira \\
\hline OECD & $\begin{array}{l}\text { Organization for Economic Cooperation and } \\
\text { Development ou Organização para a Cooperação e } \\
\text { Desenvolvimento Econômico }\end{array}$ \\
\hline ONU & Organização das Nações Unidas \\
\hline PIB & Produto Interno Bruto \\
\hline $\mathrm{PCl}$ & Placa de circuito impresso \\
\hline PMT & $\begin{array}{l}\text { Departamento de Engenharia Metalúrgica e de } \\
\text { Materiais da Escola Politécnica da USP }\end{array}$ \\
\hline PNRS & Política Nacional de Resíduos Sólidos \\
\hline PQI & $\begin{array}{l}\text { Departamento de Engenharia Química da Escola } \\
\text { Politécnica da USP }\end{array}$ \\
\hline REEE & Resíduo de equipamento eletroeletrônico \\
\hline RSU & Resíduos Sólidos Urbanos \\
\hline SCM & $\begin{array}{l}\text { Shrinking Core Model ou Modelo do Núcleo Não- } \\
\text { Reagido }\end{array}$ \\
\hline SDP-MDIC & $\begin{array}{l}\text { Secretaria de Desenvolvimento da Produção do } \\
\text { Ministério do Desenvolvimento, Indústria e Comércio } \\
\text { Exterior }\end{array}$ \\
\hline SPM & $\begin{array}{l}\text { Shrinking Particle Model ou Modelo da Partícula de } \\
\text { Tamanho Decrescente }\end{array}$ \\
\hline SQD & Somatória dos quadrados das diferenças \\
\hline UFRGS & Universidade Federal do Rio Grande do Sul \\
\hline UNDESA & $\begin{array}{l}\text { United Nations Department of Economic and Social } \\
\text { Affairs ou Departamento de Assuntos Econômicos e } \\
\text { Sociais das Nações Unidas }\end{array}$ \\
\hline UNEP & $\begin{array}{l}\text { United Nations Environmental Programme ou } \\
\text { Programa das Nações Unidas para o Meio Ambiente }\end{array}$ \\
\hline UNESP & Universidade Estadual Paulista \\
\hline UNICAMP & Universidade Estadual de Campinas \\
\hline UNU & $\begin{array}{l}\text { United Nations University ou Universidade das Nações } \\
\text { Unidas }\end{array}$ \\
\hline US & Universidade de São Paulo \\
\hline
\end{tabular}




\section{LISTA SÍMBOLOS}

$\begin{array}{ll}E_{h} & \text { potencial de oxirredução } \\ E_{a} & \text { energia de ativação } \\ P_{i} & \text { preço do metal } i \text { baseado em sua cotação na LME } \\ V_{i} & \text { valor associado ao metal } i \\ X_{B} & \text { fração reagida da reação } \\ m_{i} & \text { massa do metal } i \\ \mu \mathrm{m} & \text { micrometro } \\ \mathrm{K} & \text { constante aparente de velocidade da reação } \\ \mathrm{K} & \text { Kelvin } \\ \mathrm{L} & \text { litro } \\ \mathrm{Oz} & \text { onça troy } \\ \mathrm{R} & \text { constante universal dos gases } \\ \mathrm{T} & \text { temperatura } \\ \text { ton } & \text { tonelada métrica } \\ \tau & \text { tempo total da reação química }\end{array}$




\section{INTRODUÇÃO}

O conceito de obsolescência programada foi criado pelas indústrias do século XX. Com a queda no consumo causada pela crise econômica de 1929, a obsolescência programada consolidou-se como uma estratégia da indústria para retomar o crescimento (Silva M. O., 2012).

Esta obsolescência programada ocorre quando um produto é concebido para durar um determinado tempo em perfeito funcionamento, e após este período alguns componentes do equipamento se desgastam e deixam de funcionar, tornando o equipamento um objeto sem a funcionalidade original (Waldman, 1996).

O problema reside no fato de que o conserto deste equipamento através da troca somente dos componentes danificados é economicamente desfavorável ao consumidor, que enxerga como opção razoável a compra de um equipamento novo e mais moderno, e o consequente descarte do equipamento quebrado ou obsoleto (Schmalensee, 1970).

Em outras palavras, a aquisição de novos equipamentos em determinados e curtos - períodos é amplamente incentivada pela indústria de bens de consumo. Isto fez com que a demanda por novos produtos aumentasse ao longo destes últimos anos até chegarmos ao nível em que nos encontramos hoje: eletrodomésticos e aparelhos eletrônicos são veemente descartados após o período pré-determinado para suas vidas úteis (Duran, 2014).

Como consequência deste comportamento mercadológico e novos parâmetros de consumo, o volume de resíduos de equipamentos eletroeletrônicos (REEE) gerado pelo descarte indiscriminado de produtos ainda em condições de uso tem atingido números alarmantes (United Nations University, 2012).

Especialmente para as nações mais desenvolvidas, onde a legislação ambiental é mais rígida e a população é ambientalmente mais consciente, a preocupação com o descarte ou reaproveitamento destes resíduos é frequentemente pauta de reuniões com líderes, chefes de estado, acadêmicos, pesquisadores e ambientalistas (KHETRIWAL et al., 2011).

Um dos itens atualmente mais discutidos é a questão do descarte de placas de circuito impresso. As placas de computadores pessoais atuais, por exemplo, 
possuem ciclo de vida curto e em questão de dois a três anos se tornam obsoletos, gerando quantidades significativas de REEE em todo o planeta (Yamane L. H., 2012). As placas-mãe de computadores pessoais de mesa apresentam em sua composição cerca de 22,1\% em massa de cobre e 3,1\% em massa de ferro em relação à massa total (Correa, Tenório, \& Espinosa, Processamento Mecânico das Placas Mães de Computadores, 2014). Apesar do ferro possuir valor econômico específico menor que o do cobre no mercado de commodities, a sua presença interfere negativamente na extração do cobre durante o processo de lixiviação ácida (Ramunno, 2015).

Tendo este cenário como parâmetro inicial e considerando os resultados de pesquisas em diversos países diferentes, este trabalho apresenta um estudo cinético da lixiviação ácida de ferro de placas de circuito impresso (PCl), buscando avaliar se durante o processo de reciclagem de REEE a separação magnética traz benefícios efetivos ao rendimento do processo de recuperação de cobre destas $\mathrm{PCl}$. 


\title{
2 REVISÃo DA LITERATURA
}

\subsection{RESÍDUOS SÓLIDOS}

A sociedade moderna leva a questão do consumo muito a sério, mas tem tratado com displicência e descaso um problema que afeta todo o equilíbrio do ecossistema mundial: o lixo.

No Brasil, para regulamentar o que até então era chamado genericamente de lixo, a Associação Brasileira de Normas Técnicas (ABNT) quase três décadas atrás definiu resíduo sólido como:

\begin{abstract}
"Resíduos nos estados sólido e semissólido, que resultam de atividades da comunidade de origem industrial, doméstica, hospitalar, comercial, agrícola, de serviços e de varrição. Ficam incluídos nesta definição os lodos provenientes de sistemas de tratamento de água, aqueles gerados em equipamentos e instalações de controle de poluição, bem como determinados líquidos cujas particularidades tornem inviável o seu lançamento na rede pública de esgotos ou corpos de água, ou exijam para isso soluções técnicas e economicamente inviáveis em face a melhor tecnologia disponível" (ABNT, 1987).
\end{abstract}

Desde a Revolução Industrial, o solo e o subsolo têm sido sistematicamente transformados em depósitos para grande parte dos resíduos gerados pela civilização moderna, em especial as populações urbanas (Ribeiro \& Lima, 2000). Isto se torna um problema à medida em que estes depósitos começam a contaminar o solo e o subsolo, os lençóis freáticos e o ar, e começam a gerar problemas de natureza social no entorno destes depósitos. O problema fica ainda mais grave quando o volume de resíduos gerados é maior que a capacidade de absorção ou tratamento destes rejeitos.

Segundo a Associação Brasileira de Empresas de Limpeza Pública e Resíduos Especiais (Abrelpe), no Brasil foram gerados aproximadamente 209 mil toneladas de resíduos sólidos urbanos por dia em 2013, contra uma geração de 201 mil toneladas por dia no ano anterior; ou seja, um crescimento de 4,1\%. Comparando este aumento na geração de RSU à taxa de crescimento populacional - 
que foi de 3,7\% entre os anos de 2012 e 2013 -, nota-se uma disparidade nos valores e como resultado um aumento na taxa de geração de resíduos per capita, conforme mostra a Figura 1 (Abrelpe, 2014).

Geração de RSU

(t/dia)

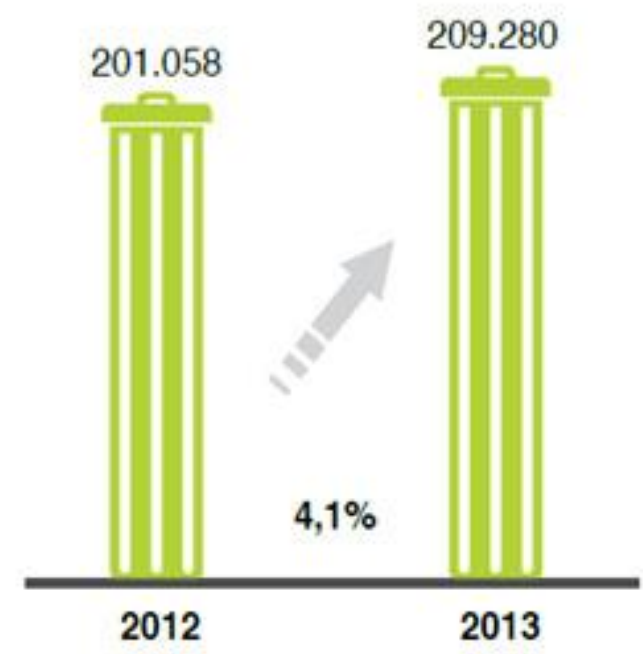

\section{Geração de RSU per capita \\ (kg/hab./dia)}

Figura 1 - Aumentos na geração de Resíduos Sólidos Urbanos e na geração de RSU per capita entre os anos de 2012 e 2013 no Brasil (ABRELPE, 2014; IBGE, 2014).

Nota: os índices per capita referentes a 2012 e 2013 foram calculados com base na população total dos municípios.

Através destes indicadores, conclui-se que a população brasileira segue uma tendência mundial de crescimento no volume de geração de resíduos per capita, principalmente nos grandes centros urbanos e nos países em desenvolvimento (Abrelpe, 2014).

De fato, de acordo com a Organização para a Cooperação e Desenvolvimento Econômico (OCDE), tanto os países desenvolvidos estudados pela OCDE quanto os em desenvolvimento como o Brasil apontam para o crescimento na taxa de geração de RSU per capita, mesmo com a redução no peso específico destes resíduos (Campos H. K., 2012).

Quando se observa a taxa de coleta destes resíduos no Brasil, nota-se um avanço de 0,3 pontos percentuais em relação ao aumento no volume de RSU gerado: segundo pesquisas da Abrelpe, em 2012 foram coletados 181.288 toneladas de RSU por dia, enquanto em 2013 este número foi de 189.219 toneladas; um crescimento de 
4,4\%, portanto superior ao aumento percentual no volume de geração de resíduos, conforme mostra a Figura 2 (Abrelpe, 2014).

\section{Coleta de RSU \\ (t/dia)}

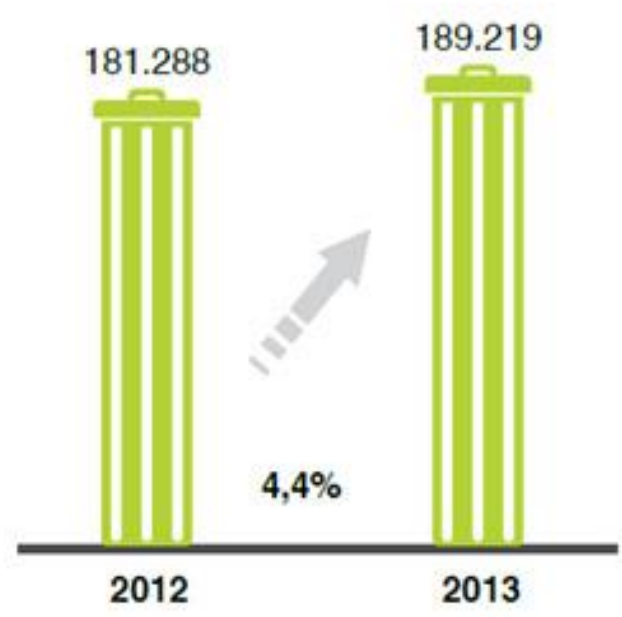

Coleta de RSU per capita

(kg/hab./dia)

Figura 2 - Aumentos na quantidade de Resíduos Sólidos Urbanos coletados e na coleta de RSU per capita entre os anos de 2012 e 2013 no Brasil (ABRELPE, 2014; IBGE, 2014).

Nota: os índices per capita referentes a 2012 e 2013 foram calculados com base na população total dos municípios.

Conclui-se, desta forma, que diariamente mais de 20.000 toneladas de resíduos deixaram de ser devidamente coletados e, por consequência, tiveram destino impróprio (Abrelpe, 2014).

Por destino impróprio entende-se como a disposição destes resíduos em locais a céu aberto sem preparo da infraestrutura do local e sem qualquer tratamento do rejeito, ocasionando na percolação dos líquidos, na liberação de gases tóxicos para a atmosfera e na proliferação de vetores de doenças (Muñoz, 2002).

É, portanto, essencial ao desenvolvimento sustentável de uma civilização que a questão do tratamento dos resíduos seja tratada com atenção.

Entretanto, para viabilizar o tratamento destes resíduos, é necessário classificá-los para otimizar os processos de tratamento e reciclagem de RSU. A ABNT então estipulou os critérios para classificação destes rejeitos. 


\subsection{CLASSIFICAÇÃO DOS RESÍDUOS SÓLIDOS}

Em 2004, a ABNT divulgou uma revisão da norma NBR 10.004, na qual definidos os critérios para classificação dos resíduos sólidos com o objetivo de classificá-los quanto aos seus riscos potenciais ao meio ambiente e à saúde pública, e para que pudessem ser gerenciados adequadamente (ABNT, 2004).

Desta forma, para os efeitos desta norma, os resíduos foram classificados em:

a) Resíduos Classe I - Perigosos;

b) Resíduos Classe II - Não Perigosos;

- Resíduos Classe II A - Não Inertes;

- Resíduos Classe II B - Inertes.

Os Resíduos Classe I - Perigosos são aqueles que apresentam periculosidade quanto aos quesitos de inflamabilidade, corrosividade, reatividade, toxicidade e patogenicidade.

Os Resíduos Classe II B - Inertes obedecem ao seguinte disposto:

"Quaisquer resíduos que, quando amostrados de uma forma representativa, segundo a ABNT NBR 10007, e submetidos a um contato dinâmico e estático com água destilada ou deionizada, à temperatura ambiente, conforme ABNT NBR 10006, não tiverem nenhum de seus constituintes solubilizados a concentrações superiores aos padrões de potabilidade de água, excetuando-se aspecto, cor, turbidez, dureza e sabor" (ABNT, 2004).

Por fim, os Resíduos Classe II A - Não Inertes são aqueles que não se enquadram nas classificações de resíduos Classe I ou Classe II B.

De uma forma simplificada, é possível utilizar o fluxograma apresentado no corpo da própria NBR 10.004:2004 para caracterizar e classificar a classe do resíduo, conforme ilustra a Figura 3 (ABNT, 2004). 


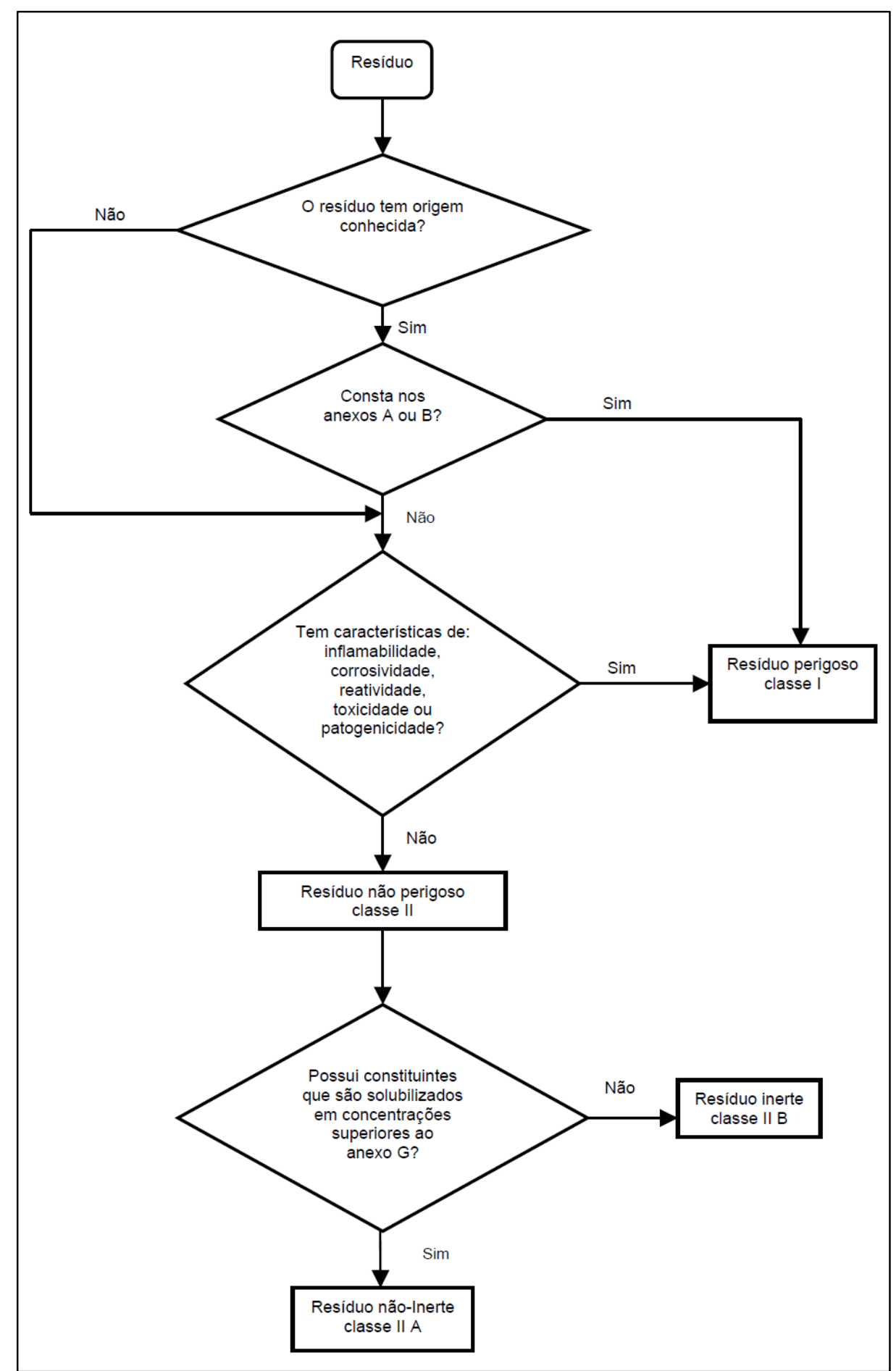

Figura 3 - Fluxograma para caracterização e classificação do resíduo sólido segundo norma ABNT-NBR 10.004:2004 (ABNT, 2004).

Um tipo de resíduo sólido em particular tem sido motivo de discussões e preocupações em diversos países ao redor do mundo devido principalmente ao volume que é gerado de resíduo todos os anos, às taxas crescentes de geração deste resíduo por habitante anualmente, e ainda pelo potencial de geração de valor a partir 
deste resíduo: trata-se do resíduo de equipamentos eletroeletrônicos, ou REEE (United Nations Environment Programme, 2007).

\subsection{RESÍDUOS DE EQUIPAMENTOS ELETROELETRÔNICOS}

Equipamentos eletroeletrônicos, de acordo com as notas publicadas pelo Ministério do Desenvolvimento da Indústria e Comércio Exterior, são todos os produtos cujo funcionamento depende do uso de corrente elétrica ou de campos eletromagnéticos, e podem ser basicamente divididos em quatro categorias: Linha Branca, Linha Marrom, Linha Azul e Linha Verde (MDIC, 2013).

A Tabela 1 (MDIC, 2013) lista alguns exemplos de produtos dentro de suas respectivas categorias.

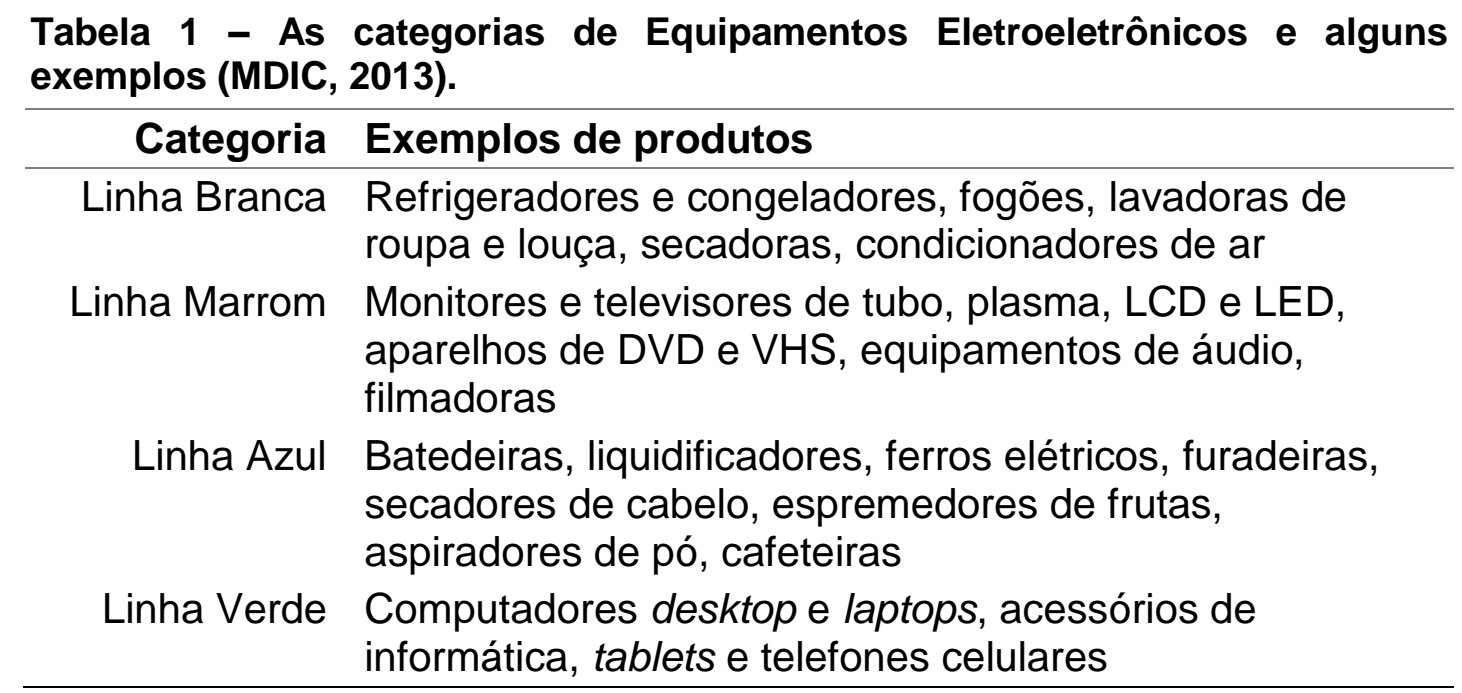

Pode ser considerado resíduo de equipamento eletroeletrônico todo material descartado proveniente de um processo de manufatura que possui, ou tenha em sua constituição, componentes eletrônicos (Aisse, Obladen, \& Santos, 1981). Os resíduos de equipamentos eletroeletrônicos - também conhecidos popularmente por "lixo eletrônico" - são, portanto, gerados a partir do descarte de aparelhos obsoletos, defeituosos ou quebrados; são produtos que perderam sua funcionalidade e que serão, em sequência, descartados (Widmer \& Lombard, 2005). 


\subsubsection{Volume de resíduos eletroeletrônicos}

Em 2012, a produção de REEE no mundo alcançou 49 milhões de toneladas métricas (United Nations University, 2012), ou aproximadamente sete quilos de resíduos por cada habitante do planeta. Dada a estatística de que a população nas cidades em países em desenvolvimento cresce à taxa de 150.000 cidadãos todos os dias (UNDESA, 2005), estima-se que até 2017 o volume de produção de REEE aumente 33\%, atingindo alarmantes 65,4 milhões de toneladas métricas (United Nations University, 2013).

Uma pesquisa apresentada pela Step Initiative (United Nations University, 2013), uma aliança entre a Organização das Nações Unidas, empresas, governos e organizações não-governamentais, apontou que em 2012 China e Estados Unidos foram os dois países que mais manufaturaram equipamentos elétricos e eletrônicos (11,1 e 10,0 milhões de toneladas, respectivamente), e consequentemente os que mais geraram REEE: 7,3 e 9,4 milhões de toneladas, respectivamente.

A Tabela 2 (INVENTTA, CIA WORLDFACTBOOK e UNITED NATIONS UNIVERSITY, 2013) mostra a relação entre a renda per capita de uma nação e a geração de REEE em quilos por habitante.

\begin{tabular}{lcc}
$\begin{array}{l}\text { Tabela } 2 \text { - Relação de países com as suas rendas per capita e a } \\
\text { relação com o volume de geração de REEE } \\
\text { WORLDFACTBOOK e UNITED NATIONS UNIVERSITY, 2013). }\end{array}$ \\
\hline País & $\begin{array}{c}\text { PIB } \\
\text { (USD/hab.) }\end{array}$ & $\begin{array}{c}\text { Geração de REEE } \\
\text { (kg/hab.) }\end{array}$ \\
\hline País & 34.600 & 23,2 \\
& 30.900 & 23,0 \\
Dinamarca & 30.400 & 14,6 \\
Alemlândia & 30.300 & 29,4 \\
Reino Unido & 29.900 & 24,0 \\
França & 29.800 & 23,9 \\
Suécia & 16.700 & 8,2 \\
Estônia & 16.300 & 11,4 \\
Hungria & 13.700 & 6,3 \\
Lituânia & 13.300 & 8,4 \\
Polônia & 9.600 & 5,7 \\
Bulgária & 11.900 & 4,8 \\
Brasil (mín. 2011) & 11.900 & 7,2 \\
Brasil (máx. 2016) & & \\
\hline
\end{tabular}


No Brasil, em 2012 foram postos no mercado cerca de 2,0 milhões de novos equipamentos elétricos e eletrônicos; ao mesmo tempo, foram gerados 1,4 milhão de toneladas de lixo eletrônico (United Nations University, 2013).

Não obstante, segundo a Agência Portal Brasil, um estudo encomendado pela Secretaria de Desenvolvimento da Produção do Ministério do Desenvolvimento, Indústria e Comércio Exterior (SDP-MDIC) e pela Agência Brasileira de Desenvolvimento Industrial (ABDI) indicou que os 150 maiores municípios brasileiros - em sua maioria nas regiões Sudeste e Sul do país - foram responsáveis por aproximadamente dois terços de todo o REEE gerado em 2014 (Agência Portal Brasil, 2014).

Devido a estes volumes de REEE que têm sido gerados ao redor do mundo, junto ao fato de que grande parte dos resíduos sólidos urbanos (RSU) gerados nas metrópoles das nações em desenvolvimento são despejados de maneira mais ou menos descontrolada em aterros sanitários - que na maioria das vezes são usos da terra economicamente desinteressantes (Zurbrugg, 2003) -, torna-se financeira e ambientalmente atrativo explorar métodos de recuperação de materiais valiosos a partir destes resíduos, tais como metais preciosos e metais de base (GUO et al., 2010).

\subsubsection{Composição dos REEE}

Os REEE são estruturas complexas que apresentam em sua composição diversos materiais metálicos, cerâmicos e poliméricos (CALDAS et al., 2014).

Como resultado das mais diversas funções que cada aparelho elétrico ou eletrônico deve realizar, das contínuas melhorias no desempenho destes equipamentos e da incessante busca pelas reduções de custos nas suas fabricações, a gama dos materiais contidos nos REEE é vasta e sua composição é variável (Chancerel \& Rotter, 2009).

Até mesmo entre aparelhos com as mesmas funcionalidades como placasmãe de impressoras a jato de tinta, por exemplo, verificam-se variações nas quantidades de metais e outros materiais encontrados em suas composições, o que complica os processos de reciclagem (SILVAS et al., 2014), consequentemente refletindo nos custos desta alternativa e criando barreiras à sua popularização. 
A Tabela 3 (WIDMER et al., 2005) lista os elementos que compõem um resíduo de equipamento eletro eletrônico típico e as porcentagens em massa de cada componente.

\begin{tabular}{|c|c|}
\hline Composição & \% em massa \\
\hline Ferro e aço & 47,9 \\
\hline Plástico sem retardante de chama & 15,3 \\
\hline Cobre & 7,0 \\
\hline Vidro & 5,4 \\
\hline Plástico com retardante de chama & 5,3 \\
\hline Alumínio & 4,7 \\
\hline Placas de Circuito Impresso & 3,1 \\
\hline Outros & 4,6 \\
\hline Madeira & 2,6 \\
\hline Cerâmica & 2,0 \\
\hline Outros metais não-ferrosos & 1,0 \\
\hline Borracha & 0,9 \\
\hline
\end{tabular}

Por conter em sua composição metais que oferecem riscos à saúde humana como o antimônio, berílio, chumbo, estanho, mercúrio, cádmio, entre diversos outros (Bizzo, 2007), o descarte dos REEE requer certos cuidados adicionais quando comparados ao descarte do lixo comum (Ferreira Junior, 2013).

A ABNT, por exemplo, através da NBR 10.004:2004 classifica como resíduos perigosos as cinzas provenientes da incineração de placas de circuito impresso (código de identificação F043), devido à incineração ser uma prática comum no tratamento dos REEE (Yamane L. H., 2012).

De fato, os REEE podem ser abordados como uma mistura complexa de resíduos classificados como perigosos e não-perigosos e que contém itens de interesse econômico. Logo, estes resíduos requerem tratamentos específicos de separação, coleta, transporte, tratamento e descarte (United Nations Environment Programme, 2007).

A Tabela 4 relaciona alguns dos componentes potencialmente perigosos à saúde que são frequentemente encontrados nos REEE (CUI et al., 2003; TSYDENOVA et al., 2011). 
Tabela 4 - Relação dos componentes presentes nos REEE que oferecem riscos à saúde humana seguidos de descrição (CUI et al., 2003; TSYDENOVA et al., 2011).

\begin{tabular}{|c|c|}
\hline Materiais e componentes & Descrição \\
\hline Baterias & $\begin{array}{l}\text { Metais como chumbo, mercúrio e } \\
\text { cádmio podem estar presentes nas } \\
\text { baterias. }\end{array}$ \\
\hline Telas de tubos de raios catódicos & $\begin{array}{l}\text { Chumbo no cone de vidro e camada } \\
\text { fluorescente que cobre o interior do } \\
\text { painel de vidro. }\end{array}$ \\
\hline $\begin{array}{r}\text { Componentes contendo mercúrio } \\
\text { (p.e. interruptores) }\end{array}$ & $\begin{array}{l}\text { Mercúrio é usado em termostatos, } \\
\text { sensores, relés e interruptores. } \\
\text { Também é usado em equipamentos } \\
\text { médicos, transmissores de dados, } \\
\text { telecomunicação e celulares. }\end{array}$ \\
\hline $\begin{array}{r}\text { Cartuchos de tinta, líquida ou } \\
\text { pastosa, assim como cartuchos } \\
\text { coloridos }\end{array}$ & $\begin{array}{l}\text { Toners e cartuchos de tinta têm que } \\
\text { ser removidos e coletados } \\
\text { separadamente devido à tinta residual } \\
\text { que pode conter metais como } \\
\text { chumbo. }\end{array}$ \\
\hline Placas de circuito impresso (PCI) & $\begin{array}{l}\text { Nas placas de circuito impresso, } \\
\text { ocorre cádmio em certos } \\
\text { componentes, como por exemplo } \\
\text { chips, detectores e semicondutores. } \\
\text { Ocorre chumbo nas soldas. }\end{array}$ \\
\hline $\begin{array}{r}\text { Capacitores contendo bifenilas } \\
\text { policloradas }\end{array}$ & $\begin{array}{l}\text { Capacitores têm que ser removidos, } \\
\text { pois caso venham a ser incinerados, } \\
\text { geram gases tóxicos. }\end{array}$ \\
\hline $\begin{array}{r}\text { Plásticos contendo retardadores } \\
\text { de chama halogenados }\end{array}$ & $\begin{array}{l}\text { Durante a incineração ou combustão } \\
\text { do plástico com retardadores de } \\
\text { chama halogenados, pode ocorrer o } \\
\text { desprendimento de gases tóxicos }\end{array}$ \\
\hline $\begin{array}{r}\text { Equipamentos contendo CFC, } \\
\text { HCFC ou HFCs }\end{array}$ & $\begin{array}{l}\text { CFC ou HCFC presentes na espuma e } \\
\text { no circuito de refrigeração devem ser } \\
\text { cuidadosamente extraídos e } \\
\text { destruídos, e o mercúrio deve ser } \\
\text { removido. }\end{array}$ \\
\hline
\end{tabular}


Há, entretanto, uma parcela da composição do REEE que desperta interesse econômico; um dos materiais que podem ser encontrados no REEE e que possui esta característica, por exemplo, é o ouro, um metal precioso que apresenta imediata liquidez no mercado mundial (Behnamfard, Salarirad, \& Veglio, 2013).

Todos os anos aproximadamente 320 toneladas de ouro são utilizadas na produção de equipamentos eletroeletrônicos como microcomputadores, laptops, tablets e aparelhos de telefonia celular, o que em 2011 correspondeu a $7,7 \%$ da sua disponibilidade mundial (Agência Fapesp, 2012).

Além do ouro, há diversos outros elementos de interesse comercial presentes nos REEE. Prata, cobre, níquel, alumínio e ferro são alguns dos metais frequentemente encontrados nestes resíduos. É possível ainda encontrar elementos de terras raras como tântalo (Ta), gálio $(\mathrm{Ga})$, índio $(\mathrm{In})$, titânio (Ti), germânio $(\mathrm{Ge})$, selênio (Se) e telúrio (Te) (KASPER, et al., 2011).

A agência MetalPrices, que é referência mundial em serviços de inteligência de mercado para a indústria internacional de metais, apresenta a sua metodologia de cálculo do valor associado a cada metal a partir da Equação 1:

$$
V_{i}=100 \times \frac{\% m_{i} P_{i}}{\sum \% m_{i} P_{i}}
$$

onde $V_{i}$ é o valor associado ao metal $i, \% m_{i}$ é a porcentagem em massa deste metal presente no REEE, e $P_{i}$ é o preço deste mesmo metal baseado em sua cotação na LME (MetalPrices, 2015).

Dentre a infinidade de tipos diferentes de REEE, há um componente dos equipamentos eletroeletrônicos que bem exemplifica a gama de materiais utilizados em sua fabricação, e que tem ganhado notoriedade devido à sua expressiva participação no volume total de resíduos gerados: são as placas de circuito impresso $(\mathrm{PCl})$.

\subsection{PLACAS DE CIRCUITO IMPRESSO}

As placas de circuito impresso são elementos fundamentais na construção de circuitos integrados e desempenham basicamente as três seguintes funções (Klimach \& Fabris, 2012): 
i) Sustentar os componentes eletrônicos como resistores, capacitores, transistores, indutores e diodos;

ii) Interligar eletricamente seus terminais; e

iii) Fornecer pontos de entrada e saída para os circuitos com conexões externas.

A Figura 4 mostra alguns exemplos típicos de PCl.

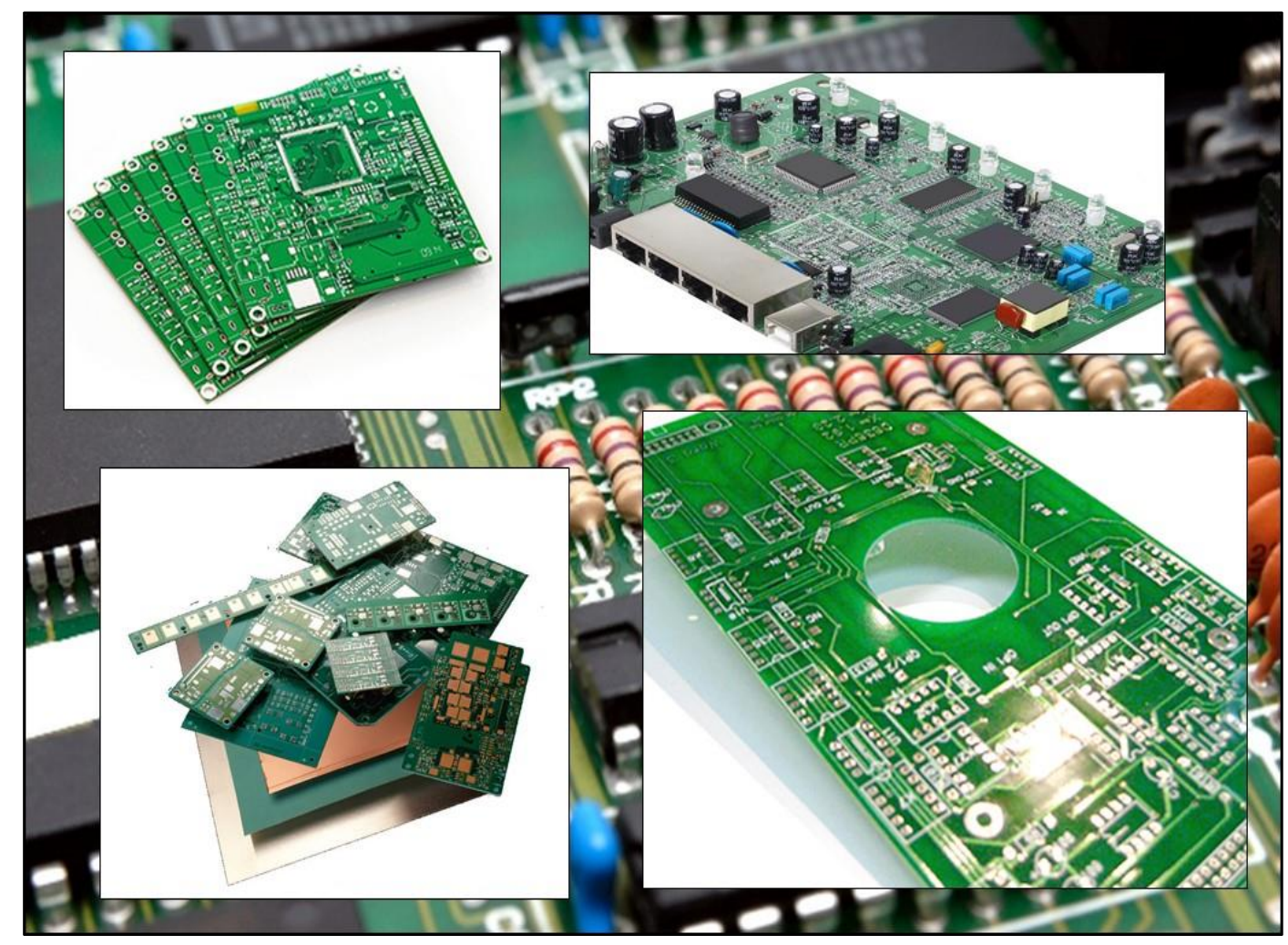

Figura 4 - Imagens com exemplos de Placas de Circuito Impresso (Google Imagens, acesso em 11 de maio de 2015; adaptação do autor).

As $\mathrm{PCl}$ são constituídas por placas isolantes elétricas nas quais são impressas ou depositadas trilhas de metal condutor - geralmente cobre - que interligam os componentes elétricos e eletrônicos que realizam e controlam as funções do sistema ou equipamento a que pertencem (Melo, Rios, \& Gutierrez, 2001).

Como exemplo ilustrativo do quão relevante é a presença de $\mathrm{PCl}$, a Tabela 5 (XAVIER et al., 2012) apresenta o percentual de massa destas placas na composição de computadores pessoais de mesa (desktops) e portáteis (laptops). 
Tabela 5 - Percentual de massa dos componentes de computadores pessoais de mesa e portáteis (XAVIER et al., 2012).

\begin{tabular}{rcc} 
Materiais & $\begin{array}{c}\text { Percentual de } \\
\text { massa desktop }\end{array}$ & $\begin{array}{c}\text { Percentual de } \\
\text { massa laptop }\end{array}$ \\
\hline Ferro & $67 \%$ & $12 \%$ \\
PCI & $15 \%$ & $8 \%$ \\
Plásticos & $7 \%$ & $31 \%$ \\
Alumínio & $6 \%$ & $20 \%$ \\
Fio e cabos & $5 \%$ & $11 \%$ \\
Vidro & - & $18 \%$ \\
\hline TOTAL & $\mathbf{1 0 0} \%$ & $\mathbf{1 0 0} \%$ \\
\hline
\end{tabular}

Dada a participação destes componentes na massa total dos equipamentos eletroeletrônicos - neste caso específico, de computadores pessoais - surgiu a necessidade de um estudo mais detalhado dos elementos que compõem estas placas com o intuito de estudar a avaliar as formas possíveis (e viáveis) de reciclagem e recuperação destes componentes.

\subsubsection{Composição das placas de circuito impresso}

As $\mathrm{PCl}$ mais modernas podem conter mais de sessenta elementos diferentes em sua composição, em alguns casos inclusive de materiais potencialmente perigosos à saúde pública (SCHLUEP et al., 2009).

Devido à miniaturização dos equipamentos eletroeletrônicos, houve necessidade de reduzir as dimensões das $\mathrm{PCl}$ e seus componentes ao mesmo tempo em que se aumentava a quantidade de operações realizadas por segundo nestes sistemas. Desta forma, os atuais processos de fabricação de $\mathrm{PCl}$ permitem que este componente apresente mais de 40 camadas, cujas espessuras chegam a medir até $18 \mu \mathrm{m}$ de espessura cada (Elco, 2015).

Tipicamente, as $\mathrm{PCl}$ constituem-se em $40 \%$ em peso de metais, $30 \%$ de materiais orgânicos e $30 \%$ de cerâmicos; a Figura 5 apresenta os componentes tipicamente encontrados nestas placas e suas respectivas frações mássicas (Luda, 2011). 


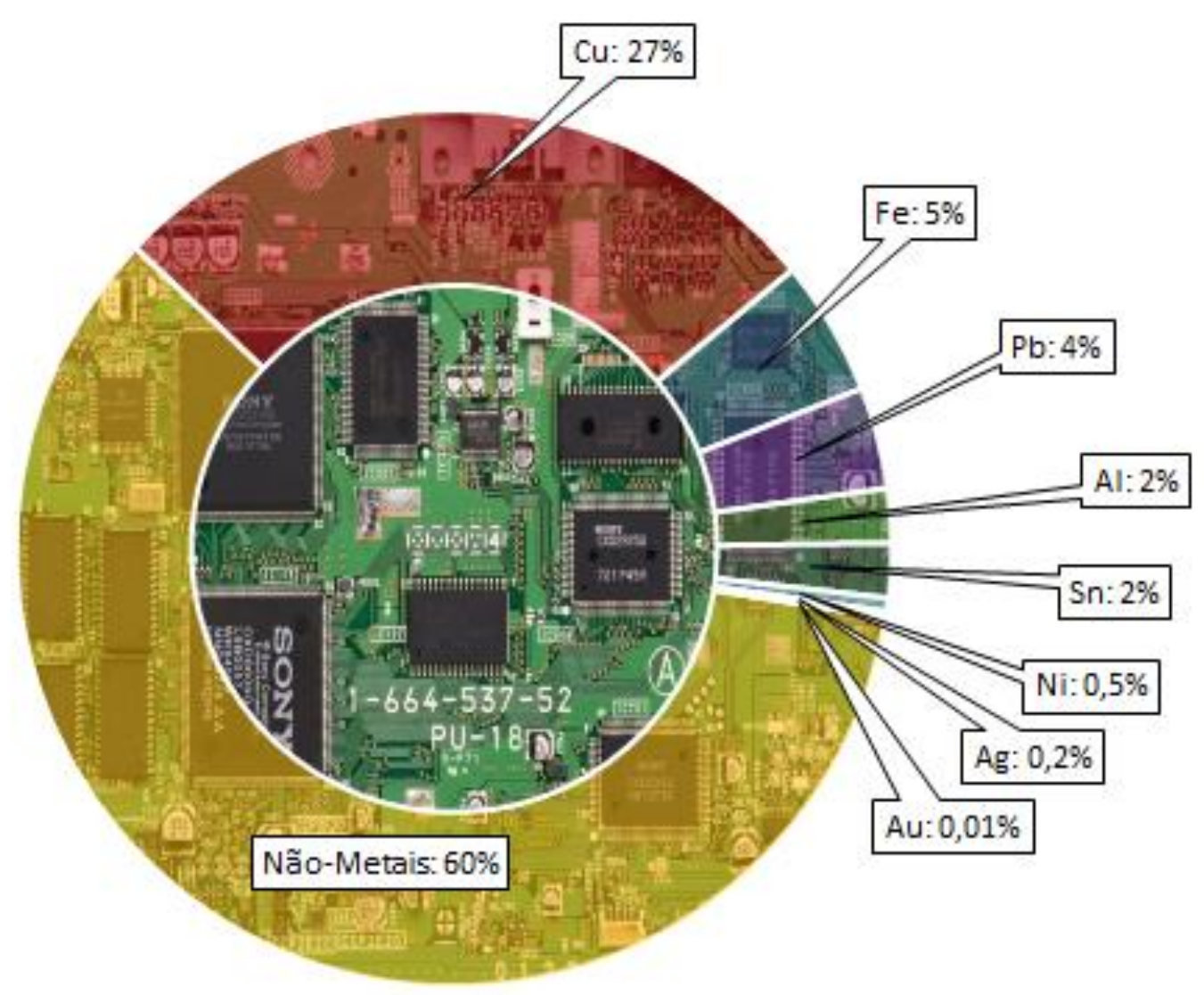

Figura 5 - Relação dos elementos que compõem uma placa de circuito impresso típica com respectivos valores percentuais em massa (LUDA, 2011; adaptação do autor).

Nota-se, logo, a presença de diversos metais de interesse econômico e comercial, tais como o paládio, o ouro, a prata, o zinco, o níquel, o estanho e o cobre.

Os metais preciosos - especialmente o ouro, a prata e o paládio - são encontrados na forma de filmes finos sobre outros metais base (alumínio, cobre ou ferro) e cerâmicos (Park \& Fray, 2009) e são aplicados principalmente como materiais de contato elétrico devido às suas estabilidades química, às suas propriedades condutoras e de resistência à corrosão (Syed, 2006).

Entre os elementos cerâmicos, são encontrados essencialmente os materiais à base de sílica, alumina, mica e titanato de bário; já a parcela de substratos orgânicos é composta por camadas de papel impregnadas com resina fenólica ou camadas de fibra de vidro impregnadas com poliamida, resina epóxi, resina BT, éster de cianeto, entre outros (Coombs Jr., 2008).

Segundo YAMANE (2012), há diversos estudos reportados nas literaturas de diversos países distintos com o objetivo de caracterizar os mais diferentes modelos 
de $\mathrm{PCl}$, que apontam para uma heterogeneidade tanto na composição quanto na concentração dos materiais - em especial dos metais - que compõem estas placas.

É preciso, entretanto, contar com políticas estruturadas para que toda a cadeia de tratamento de RSU e REEE se torne viável de forma sustentável, e que envolvam inclusive questões legais e regulatórias.

\subsection{LEGISLAÇÃO}

No Brasil, a regulamentação sobre disposição, gestão e tratamento de rejeitos - domésticos e industriais - é relativamente nova se comparada a países como os Estados Unidos, Japão e diversos países europeus. A título de comparação, o Japão possui estritas leis que tratam especificamente do REEE desde o início da década de 90 (Yamane L. H., 2012).

Alguns Estados brasileiros possuem leis estaduais específicas para a regulamentação do tratamento e gestão dos resíduos de equipamentos eletroeletrônicos, como é o caso por exemplo de São Paulo, Paraná, Mato Grosso e Pernambuco.

No outro extremo, a China é atualmente considerada a capital mundial da reciclagem do REEE, com um modelo, segundo AFONSO (2010), altamente insustentável. A Figura 6 e a Figura 7 mostram áreas urbanas na cidade de Guiyu, ao sul da província chinesa de Guangdong, onde os depósitos a céu aberto não possuem qualquer infraestrutura básica, tampouco oferecem condições de higiene e segurança do trabalho (Afonso, 2010). 


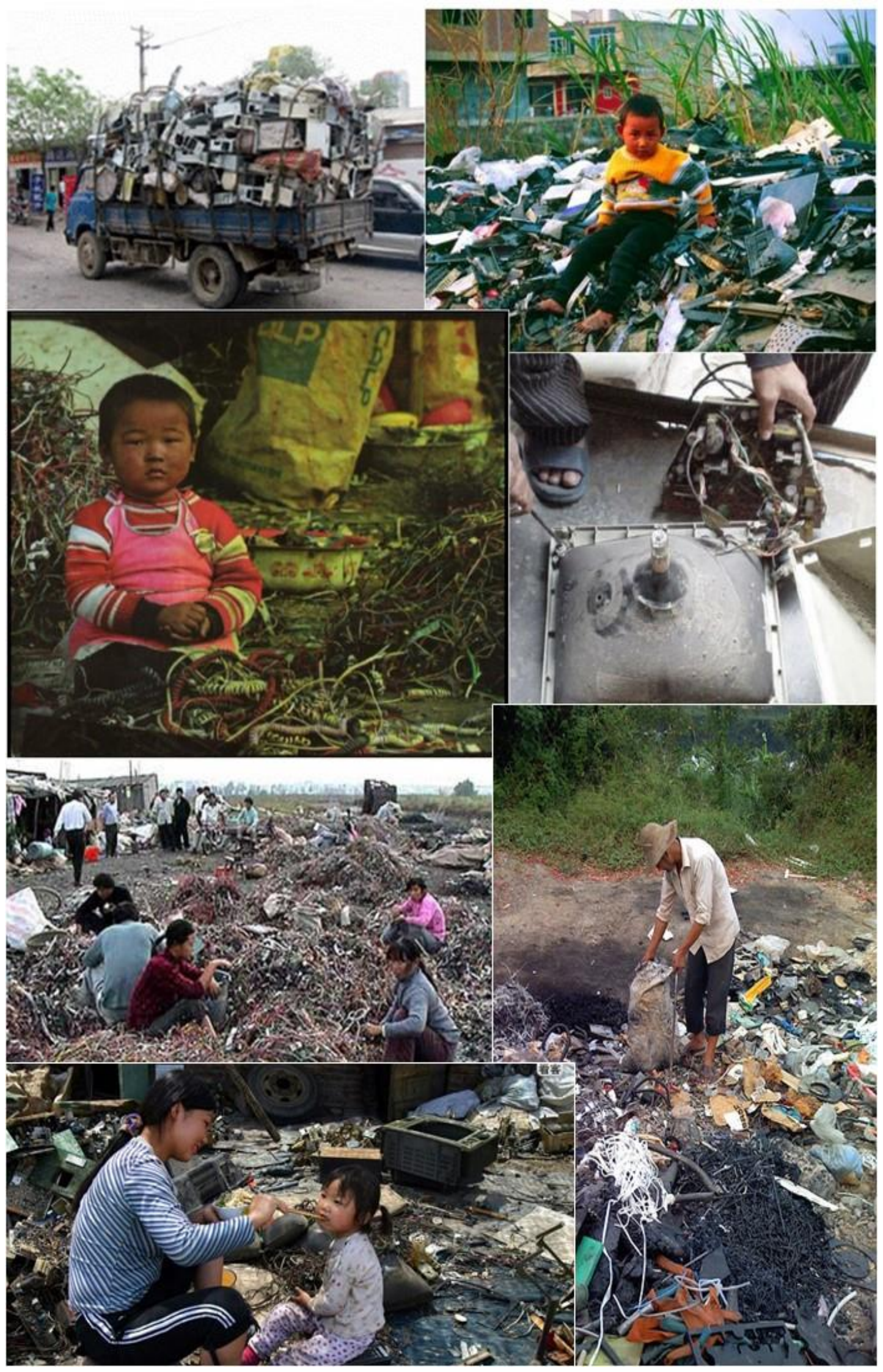

Figura 6 - Imagens da cidade de Guiyu, na província chinesa de Guangdong, onde é comum ver pessoas - adultos e crianças - conviverem com o REEE (AFONSO, 2010; adaptação do autor). 


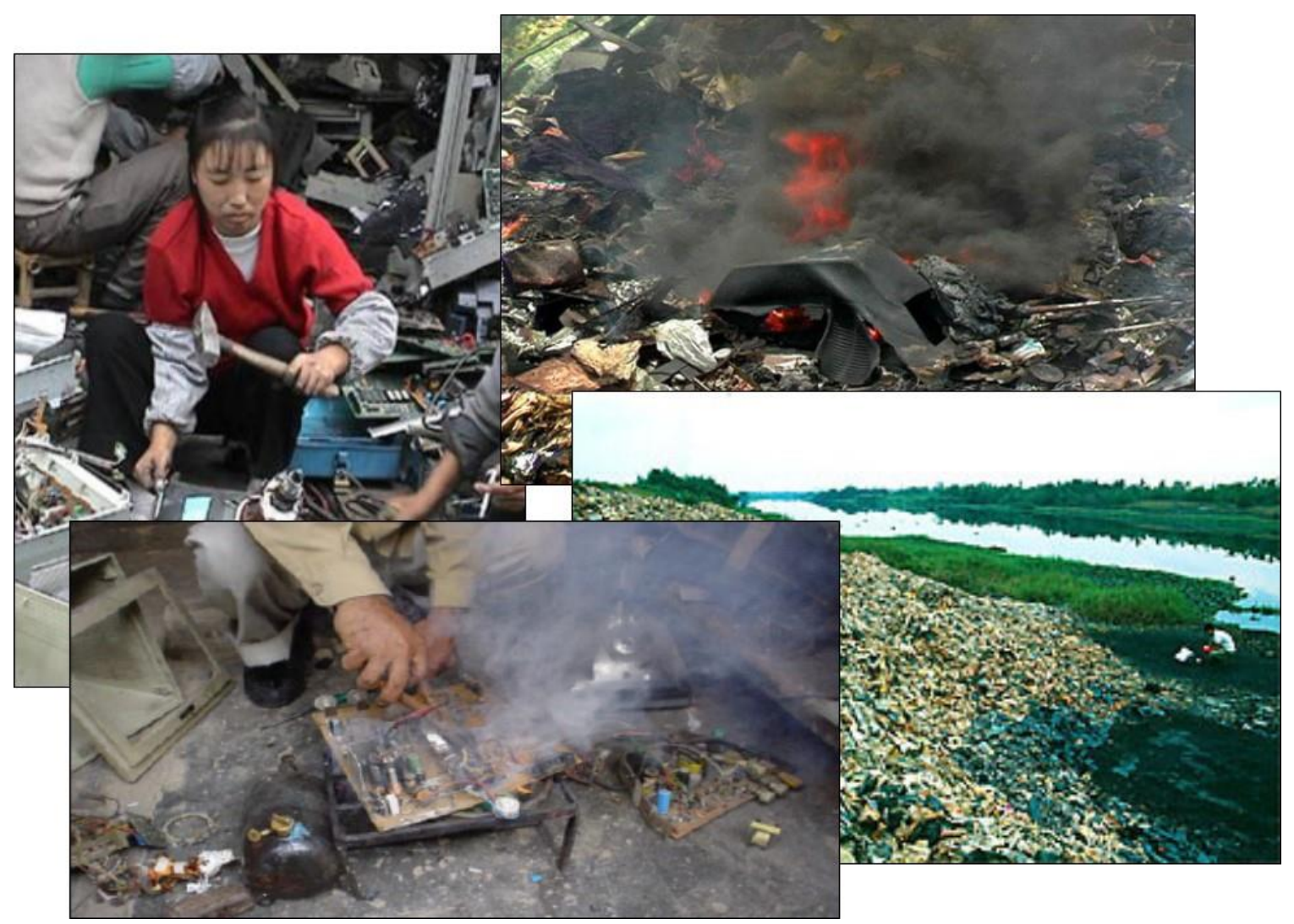

Figura 7 - Imagens da cidade de Guiyu, com pessoas trabalhando em condições precárias de higiene e segurança (AFONSO, 2010; adaptação do autor).

O Brasil se situa em uma posição intermediária entre estes extremos de Japão e China. A Política Nacional de Resíduos Sólidos (PNRS) aborda a questão dos REEE, porém sem metas, prazos e multas por descumprimento claramente estabelecidos. Atualmente, o Poder Público e os representantes setoriais discutem e negociam as propostas, sem entretanto terem chegado a um acordo (Veloso, 2014).

\subsubsection{Conselho Nacional do Meio Ambiente}

Ao viabilizar a recuperação dos materiais que compõem o REEE, independentemente do valor econômico que cada componente possui, contribui-se de forma indireta para o estudo de não-agressão ao meio ambiente (UNEP, 2009).

Segundo um relatório da Comissão Europeia, cerca de $70 \%$ dos metais tóxicos - incluindo mercúrio e cádmio - encontrados nos aterros sanitários são provenientes de REEE. Este mesmo relatório indica que $40 \%$ do chumbo encontrado nestes aterros são provenientes de equipamentos eletroeletrônicos descartados (Zumbuehl, 2006). 
Assim, o Conselho Nacional do Meio Ambiente (CONAMA, s.d.) publicou algumas Resoluções que tratam do processo de entrega pós-uso de alguns tipos específicos de resíduos, como são os casos de pneus (Resolução CONAMA no 258/1999), pilhas e baterias (Resolução CONAMA no 401/2008), agrotóxicos e suas embalagens (Resolução CONAMA no 334/2003), entre outros (FecomercioSP, 2011).

Porém, até a instituição da Política Nacional de Resíduos Sólidos, em 2010, não havia no Brasil legislação específica tratando dos RSU, detalhe que precisava ser urgentemente revisto e reconsiderado.

\subsubsection{Política Nacional de Resíduos Sólidos}

A Política Nacional de Resíduos Sólidos (PNRS) é uma política governamental instituída através da Lei Federal № 12.305, de 2 de Agosto de 2010 pela Subchefia para Assuntos Jurídicos da Casa Civil, durante o mandato do então Presidente da República Luiz Inácio Lula da Silva.

Como disposição geral, o artigo $4^{\circ}$ desta Lei define um dos papéis fundamentais da PNRS:

A Política Nacional de Resíduos Sólidos reúne o conjunto de princípios, objetivos, instrumentos, diretrizes, metas e ações adotados pelo Governo Federal, isoladamente ou em regime de cooperação com Estados, Distrito Federal, Municípios ou particulares, com vistas à gestão integrada e ao gerenciamento ambientalmente adequado dos resíduos sólidos (BRASIL, 2010).

Desta forma, o assunto principal que este documento aborda é a gestão integrada e o tratamento dos resíduos sólidos gerados em território nacional, o que incluem os REEE.

Além disto, um assunto amplamente tratado na PNRS e que gerou grande repercussão no meio empresarial foi a questão da logística reversa de resíduos, que foi estendida inclusive a todos os produtos comercializados em embalagens plásticas, metálicas ou de vidro em território brasileiro (Nogueira, 2010).

O fato a ser destacado, entretanto, é que o Brasil destina $90 \%$ dos RSU a aterros ou lixões, enquanto a quantidade de resíduos destinados a processos de reciclagem mecânica corresponde cerca de $8 \%$, e os resíduos destinados ao processo 
de compostagem correspondem a apenas 1,5\%. Segundo esta mesma referência, não há volumes significativos de resíduos que são incinerados para a geração de energia elétrica (Gonçalves, 2007).

Igualmente crítica e ainda dentro da mesma cadeia produtiva é a destinação que alguns países dão aos seus resíduos sólidos urbanos. A Tabela 6 mostra que a utilização de aterros como destino final dos resíduos gerados nem sempre tem relação direta com o nível de desenvolvimento de um país.

\begin{tabular}{|c|c|c|c|c|}
\hline País & $\begin{array}{c}\text { Aterros } \\
(\%)\end{array}$ & $\begin{array}{l}\text { Incineração com } \\
\text { recuperação } \\
\text { energética (\%) }\end{array}$ & $\begin{array}{c}\text { Compostagem } \\
(\%)\end{array}$ & $\begin{array}{c}\text { Reciclagem } \\
\text { Mecânica } \\
(\%)\end{array}$ \\
\hline Brasil & 90,0 & - & 1,5 & 8,0 \\
\hline Alemanha & 50,0 & 30,0 & 5,0 & 15,0 \\
\hline Austrália & 80,0 & $<1$ & Insignificante & 20,0 \\
\hline Dinamarca & 11,0 & 58,0 & 2,0 & 29,0 \\
\hline EUA & 55,4 & 15,5 & \multicolumn{2}{|c|}{ 29,1 (Comp.+Recicl.) } \\
\hline França & 48,0 & 40,0 & \multicolumn{2}{|c|}{ 12,0 (Comp.+Recicl.) } \\
\hline Grécia & 95,0 & - & - & 5,0 \\
\hline Holanda & 12,0 & 42,0 & 7,0 & 39,0 \\
\hline Israel & 87,0 & - & - & 13,0 \\
\hline Itália & 80,0 & 7,0 & 10,0 & 3,0 \\
\hline México & 97,6 & - & - & 2,4 \\
\hline Reino Unido & 83,0 & 8,0 & 1,0 & 8,0 \\
\hline Suécia & 40,0 & 52,0 & 5,0 & 3,0 \\
\hline Suíça & 13,0 & 45,0 & 11,0 & 31,0 \\
\hline
\end{tabular}

Tendo isto e considerando o aumento no acesso aos bens industrializados pela população brasileira - e proporcional aumento no volume de REEE gerado -, ressalta-se a importância dos governos locais em desenvolver estratégias de gestão e tratamento de resíduos sólidos junto às associações, aos empresários, ao poder público e à própria população (MMA, 2012).

No caso específico dos REEE, estes são os únicos que ainda não possuem Acordos Setoriais, uma obrigatoriedade da PNRS. O edital de chamamento para a logística reversa de equipamentos eletroeletrônicos foi aprovado em 2012. Entretanto, mais de $50 \%$ das propostas apresentadas pelas entidades representativas foram desclassificadas por não possuírem abrangência nacional (FecomercioSP, 2014). 
USHIZIMA, MARINS e MUNIZ JR. (2014) levantaram as informações sobre as Leis que instituem as Políticas Estaduais de Resíduos Sólidos para cada Estado da Federação, incluindo também os decretos que as regulamentam, e a menção aos REEE. O resultado deste levantamento é apresentado na Tabela 7.

Tabela 7 - Levantamento das situações das Políticas Estaduais de Resíduos Sólidos, leis que as instituem e decretos que as regulamentam (USHIZIMA, MARINS e MUNIZ JR., 2014; adaptação do autor).

\begin{tabular}{|c|c|c|c|c|c|c|}
\hline UF & $\begin{array}{c}\text { Plano } \\
\text { Estadual }\end{array}$ & № Lei & Data & $\begin{array}{c}\text { № } \\
\text { Decreto }\end{array}$ & Data & Menciona REEE? \\
\hline$A C$ & $\begin{array}{l}\text { Concluído } \\
\text { em2012 }\end{array}$ & - & - & - & - & - \\
\hline $\mathrm{AL}$ & $\begin{array}{c}\text { Em } \\
\text { elaboração }\end{array}$ & - & - & - & - & - \\
\hline AM & $\begin{array}{c}\text { Em } \\
\text { elaboração }\end{array}$ & - & - & - & - & - \\
\hline $\mathrm{AP}$ & - & - & - & - & - & - \\
\hline $\mathrm{BA}$ & - & 12.932 & 07.01.14 & - & - & $\begin{array}{c}\text { Sim, mesma abordagem da } \\
\text { PNRS }\end{array}$ \\
\hline CE & $\begin{array}{c}\text { Em } \\
\text { elaboração }\end{array}$ & 13.103 & 24.01 .01 & 26.604 & 16.05 .02 & Não \\
\hline DF & - & 3.232 & 03.12 .03 & 29.399 & 14.08 .08 & $\begin{array}{l}\text { Menciona REE no decreto: } \\
\text { responsabilidade do gerador } \\
\text { de resíduos }\end{array}$ \\
\hline GO & $\begin{array}{c}\text { Em } \\
\text { elaboração }\end{array}$ & 14.248 & 29.07 .02 & - & - & $\begin{array}{l}\text { Lei № } 17.242 \text { de } 27 \text { de } \\
\text { dezembro de } 2010 \text { inclui } \\
\text { equipamentos de informática } \\
\text { entre resíduos especiais: } \\
\text { responsabilidade de } \\
\text { fabricantes, importadorese } \\
\text { representantes }\end{array}$ \\
\hline MA & $\begin{array}{l}\text { Concluído } \\
\text { em } 2012\end{array}$ & - & - & - & - & - \\
\hline MG & $\begin{array}{c}\text { Em } \\
\text { elaboração }\end{array}$ & 18.031 & 12.01 .09 & 45.181 & 25.09 .09 & $\begin{array}{c}\text { Menciona REE no decreto: } \\
\text { impõe que deve ser estipulado } \\
\text { prazo para cumprimento das } \\
\text { obrigações de fabricantes, } \\
\text { importadores, revendedores, } \\
\text { comerciantes, distribuidores e } \\
\text { consumidores }\end{array}$ \\
\hline MS & $\begin{array}{c}\text { Em } \\
\text { elaboração }\end{array}$ & 2.080 & 13.01 .00 & - & - & Não \\
\hline
\end{tabular}




\begin{tabular}{|c|c|c|c|c|c|c|}
\hline UF & $\begin{array}{c}\text { Plano } \\
\text { Estadual }\end{array}$ & № Lei & Data & $\begin{array}{c}\text { № } \\
\text { Decreto }\end{array}$ & Data & Menciona REEE? \\
\hline MT & $\begin{array}{c}\text { Em } \\
\text { elaboração }\end{array}$ & 7.862 & 19.12 .02 & - & - & $\begin{array}{l}\text { REE são considerados } \\
\text { resíduos especiais: Os } \\
\text { fabricantes ou importadores de } \\
\text { produtos ou senviços que } \\
\text { gerem resíduos especiais são } \\
\text { responsáveis pelo } \\
\text { gerenciamento desses } \\
\text { resíduos }\end{array}$ \\
\hline PA & - & - & - & - & - & - \\
\hline PB & $\begin{array}{c}\text { Em } \\
\text { elaboração }\end{array}$ & - & - & - & - & - \\
\hline $\mathrm{PE}$ & $\begin{array}{l}\text { Concluído } \\
\text { em2012 }\end{array}$ & 12.008 & 01.06 .01 & 23.941 & 11.01 .02 & $\begin{array}{l}\text { Indústria Eletrônica deve } \\
\text { apresentar Plano de } \\
\text { Gerenciamento de Res. } \\
\text { Sólidos de produção, mas não } \\
\text { dos produtos comercializados. } \\
\text { Nova lei: Lei Estadual № } \\
\text { 14.236, de } 13 \text { de dezembro de } \\
2010 \text { menciona } \\
\text { responsabilidade } \\
\text { compartilhada e logística } \\
\text { reversa, mas não REE }\end{array}$ \\
\hline $\mathrm{Pl}$ & - & - & - & - & - & - \\
\hline $\mathrm{PR}$ & - & 14.943 & 22.01.99 & 6.674 & 03.12 .02 & Não \\
\hline RJ & $\begin{array}{l}\text { Concluído } \\
\text { em } 2013\end{array}$ & 4.191 & 30.09 .03 & 41.084 & 20.12 .07 & $\begin{array}{l}\text { A nova Lei Estadual no } 6.805 \\
\text { de } 18 \text { de junho de } 2014 \text { inclui } \\
\text { artigos na Lei de } 2003 \text { e } \\
\text { menciona REE (mesma } \\
\text { abordagem da PNRS) }\end{array}$ \\
\hline $\mathrm{RN}$ & $\begin{array}{l}\text { Concluído } \\
\text { em2012 }\end{array}$ & - & - & - & - & - \\
\hline RO & $\begin{array}{c}\text { Em } \\
\text { elaboração }\end{array}$ & 1.145 & 12.12 .02 & - & - & Não \\
\hline $\mathrm{RR}$ & $\begin{array}{c}\text { Em } \\
\text { elaboração }\end{array}$ & 416 & 14.01 .04 & - & - & $\begin{array}{l}\text { REE considerado lixo } \\
\text { tecnológico, inserido nos } \\
\text { resíduos especiais } \\
\text { pósconsumo: os fabricantes e } \\
\text { os importadores, que geram os } \\
\text { resíduos, são responsáveis } \\
\text { pelo seu recolhimento, pela } \\
\text { sua descontaminação, quando } \\
\text { necessária, e pela sua } \\
\text { disposição final }\end{array}$ \\
\hline
\end{tabular}




\begin{tabular}{|c|c|c|c|c|c|c|}
\hline UF & $\begin{array}{c}\text { Plano } \\
\text { Estadual }\end{array}$ & № Lei & Data & $\begin{array}{c}\text { № } \\
\text { Decreto }\end{array}$ & Data & Menciona REEE? \\
\hline RS & $\begin{array}{c}\text { Em } \\
\text { elaboração }\end{array}$ & 9.921 & 27.07 .93 & 38.356 & 01.04 .98 & $\begin{array}{c}\text { A nova Lei Estadual № } 14.528, \\
\text { de } 16 \text { de abril de } 2014 \\
\text { menciona REE (mesma } \\
\text { abordagem da PNRS) }\end{array}$ \\
\hline SC & $\begin{array}{l}\text { Concluído } \\
\text { em 2012 }\end{array}$ & 13.557 & 17.11 .05 & - & - & Não \\
\hline SE & $\begin{array}{l}\text { Concluído } \\
\text { em2013 }\end{array}$ & 5.857 & 22.03 .06 & - & - & $\begin{array}{l}\text { REEé resíduo especial: os } \\
\text { fabricantes, registrantes ou } \\
\text { importadores dos produtos e } \\
\text { bens, que dão origem aos } \\
\text { resíduos classificados como } \\
\text { especiais pós-consumo, } \\
\text { devem dispor, os resíduos } \\
\text { coletados pelos centros de } \\
\text { recepção, em locais } \\
\text { destinados para esse fim, } \\
\text { aprovados pelo órgão } \\
\text { ambiental estadual competente }\end{array}$ \\
\hline SP & $\begin{array}{l}\text { Consulta } \\
\text { Pública }\end{array}$ & 12.300 & 16.03 .06 & 54.645 & 05.08.09 & $\begin{array}{l}\text { Indústria de materiais elétricos, } \\
\text { eletrônicos e de comunicação } \\
\text { deve apresentar Plano de } \\
\text { Gerenciamento dos resíduos }\end{array}$ \\
\hline TO & $\begin{array}{c}\text { Em } \\
\text { elaboração }\end{array}$ & - & - & - & - & - \\
\hline
\end{tabular}

Alguns Estados foram além e possuem ainda suas próprias leis que abordam a questão dos REEE. A Tabela 8 (Ushizima, Marins, \& Muniz Jr., 2014) mostra algumas destas leis e as suas respectivas definições.

Tabela 8 - Leis Estaduais que abordam o tratamento e a gestão dos REEE (USHIZIMA, MARINS e MUNIZ JR., 2014; adaptação do autor).

\begin{tabular}{|c|c|c|c|}
\hline UF & Lei & Data & Definição \\
\hline ES & 9.941 & 29.11 .12 & $\begin{array}{l}\text { Lixo tecnológico - aparelhos eletrodomésticos; } \\
\text { sistemas de rede; parques de telefonia; equipamentos } \\
\text { e componentes eletroeletrônicos tais como: } \\
\text { componentes e periféricos de computadores; monitores } \\
\text { e televisores; acumuladores de energia (baterias e } \\
\text { pilhas); produtos magnetizados. } \\
\text { Comerciantes, representantes ou fabricantes } \\
\text { (importadores): devem ter pontos de coleta e fazer a } \\
\text { disposição ambientalmente adequada; fabricantes } \\
\text { devem garantir a LR, e atingir uma meta anual de } \\
\text { reciclagem. }\end{array}$ \\
\hline
\end{tabular}




\begin{tabular}{|c|c|c|c|}
\hline UF & Lei & Data & Definição \\
\hline MA & 9.291 & 16.11 .10 & $\begin{array}{l}\text { Lâmpadas, pilhas, baterias, equipamentos de } \\
\text { informática e outros tipos de acumuladores de energia. } \\
\text { Comerciantes devem manter postos de coleta para } \\
\text { receber produtos após inutilização. } \\
\text { Pilhas, baterias, equipamentos de informática, } \\
\text { carcaças de telefones celulares e seus carregadores e } \\
\text { outros tipos de acumuladores de energia que } \\
\text { contenham em sua composição chumbo, cádmio, } \\
\text { mercúrio e seus compostos necessitam de destinação } \\
\text { adequada. } \\
\text { Os fabricantes, importadores e comerciantes deverão } \\
\text { manter programas de esclarecimento dos } \\
\text { consumidores acerca da importância de entregarem os } \\
\text { produtos na rede de postos de coleta. }\end{array}$ \\
\hline MT & 8.876 & 16.05 .08 & $\begin{array}{l}\text { Lixo tecnológico - computadores, equipamentos de } \\
\text { informática, pilhas, baterias, televisores e monitores, } \\
\text { micro-ondas, máquinas fotográficas, lâmpadas } \\
\text { fluorescentes e eletroeletrônicos. } \\
\text { Todos os equipamentos que possam ser } \\
\text { reaproveitados devem ser destinados para atingir um } \\
\text { fim social. } \\
\text { Os resíduos danificados ou obsoletos devem ser } \\
\text { entregues aos estabelecimentos que comercializam ou } \\
\text { rede de assistência técnica, para que repasse aos } \\
\text { fabricantes/importadores, para que reutilizem, recicle } \\
\text { ou deem o destino ambientalmente adequado. }\end{array}$ \\
\hline PR & 15.851 & 10.06 .08 & $\begin{array}{l}\text { As empresas produtoras, distribuidoras e que } \\
\text { comercializam equipamentos de informática instaladas } \\
\text { no Estado do Paraná ficam obrigadas a criar e manter } \\
\text { o Programa de Recolhimento, Reciclagem ou } \\
\text { Destruição de Equipamentos de Informática, sem } \\
\text { causar poluição ambiental. } \\
\text { As empresas produtoras deverão promover } \\
\text { campanhas, fazendo veicular propaganda } \\
\text { esclarecendo os usuários sobre os riscos para o meio } \\
\text { ambiente de se jogarem os equipamentos em locais } \\
\text { não apropriados e os benefícios de se recolhê-los para } \\
\text { posterior destruição. }\end{array}$ \\
\hline
\end{tabular}




\begin{tabular}{cccl}
\hline UF & Lei & Data & \multicolumn{1}{c}{ Definição } \\
\hline MS 3.970 & 17.11 .10 & Lixo tecnológico - aparelhos eletrodomésticos e \\
& & & equipamentos e componentes eletroeletrônicos tais \\
& como: componentes periféricos de computadores, \\
& monitores e televisores, acumuladores de energia e \\
& produtos magnetizados. \\
& Empresas que produzem, comercializam ou importam: \\
& devem manter pontos de coleta e dar destinação \\
& ambientalmente adequada. \\
& As embalagens ou rótulos devem indicar com destaque: \\
& (i) advertência de que não sejam descartados em lixo \\
& comum; (ii) orientação sobre postos de entrega do lixo \\
& tecnológico; (iii) endereço e telefone de contato dos \\
& responsáveis pelo descarte do material em desuso \\
& sujeito à disposição final; e (iv) alerta sobre a existência \\
& de metais pesados ou substâncias tóxicas entre os \\
& componentes do produto.
\end{tabular}

PB 9.129 27.05.10 Lixo tecnológico - aparelhos eletrodomésticos e equipamentos e componentes eletroeletrônicos tais como: componentes periféricos de computadores, monitores e televisores, acumuladores de energia e produtos magnetizados.

Empresas que produzem, comercializam ou importam: devem manter pontos de coleta e dar destinação ambientalmente adequada.

As embalagens ou rótulos devem indicar com destaque: (i) advertência de que não sejam descartados em lixo comum; (ii) orientação sobre postos de entrega do lixo tecnológico; (iii) endereço e telefone de contato dos responsáveis pelo descarte do material em desuso sujeito à disposição final; e (iv) alerta sobre a existência de metais pesados ou substâncias tóxicas entre os componentes do produto.

RS 13.533 28.10.10 Lixo tecnológico - aparelhos eletrodomésticos e equipamentos e componentes eletroeletrônicos tais como: componentes periféricos de computadores, monitores e televisores, acumuladores de energia e produtos magnetizados.

Empresas que produzem, comercializam ou importam: devem manter pontos de coleta e dar destinação ambientalmente adequada.

As embalagens ou rótulos devem indicar com destaque: (i) advertência de que não sejam descartados em lixo comum; (ii) orientação sobre postos de entrega do lixo tecnológico; (iii) endereço e telefone de contato dos responsáveis pelo descarte do material em desuso sujeito à disposição final; e (iv) alerta sobre a existência de metais pesados ou substâncias tóxicas entre os componentes do produto. 


\begin{tabular}{lcll}
\hline UF Lei & Data & \multicolumn{1}{c}{ Definição } \\
\hline SP 13.576 & 06.07 .09 & Lixo tecnológico - aparelhos eletrodomésticos e \\
& & equipamentos e componentes eletroeletrônicos tais \\
& como: componentes periféricos de computadores, \\
& monitores e televisores, acumuladores de energia e \\
& produtos magnetizados. \\
& Empresas que produzem, comercializam ou importam: \\
& devem manter pontos de coleta e dar destinação \\
& ambientalmente adequada. \\
& As embalagens ou rótulos devem indicar com destaque: \\
& (i) advertência de que não sejam descartados em lixo \\
& comum; (ii) orientação sobre postos de entrega do lixo \\
& tecnológico; (iii) endereço e telefone de contato dos \\
& responsáveis pelo descarte do material em desuso \\
& sujeito à disposição final; e (iv) alerta sobre a existência \\
& de metais pesados ou substâncias tóxicas entre os \\
& componentes do produto. \\
\hline
\end{tabular}

Estes progressos nas discussões entre Poder Público e a população brasileira através de associações refletem em um certo grau de maturidade que o país tem atingido na questão de tratamento e gestão de resíduos sólidos urbanos.

Há, entretanto, um longo caminho a ser percorrido até que seja atingido um nível aceitável de sustentabilidade econômica, financeira, ambiental e social.

\subsection{TRATAMENTO DOS RESÍDUOS DE EQUIPAMENTOS ELETROELETRÔNICOS}

Há, no meio científico, inúmeros estudos indicando as mais diferentes formas para extrair os elementos metálicos dos REEE, sendo que os métodos mais comumente encontrados são aqueles feitos através de processos químicos, térmicos e mecânicos (CALDAS et al., 2014).

No caso específico das $\mathrm{PCl}$, os processos mais comumente utilizados e estudados para o tratamento destes equipamentos e recuperação de componentes de interesse específico são os processos (Santanilla, 2012):
i) Mecânicos;
ii) Pirometalúrgicos;
iii) Biohidrometalúrgicos;
iv) Eletrometalúrgicos; 

v) Hidrometalúrgicos; e
vi) Combinações destas técnicas.

\subsubsection{Processamentos mecânicos}

Os processos mecânicos constituem-se de uma ou mais operações unitárias, típicas de tratamento de minérios.

O processamento mecânico, segundo LACOR (2014), não resulta em mudanças nas propriedades físicas ou químicas dos materiais.

No caso de tratamento de REEE, estes processos mecânicos são normalmente utilizados como pré-tratamento com o intuito de aumentar a concentração da fração metálica dos resíduos, para posteriormente submetê-los a processos metalúrgicos (VEIT et al., 2008).

SANTANILLA (2012) afirma ainda que para o tratamento específico dos REEE, este resíduos são normalmente submetidos aos processos de cominuição, classificação e separação.

A Figura 8 (Lacor, 2014) mostra um esquema geral da etapa de processamento mecânico. 


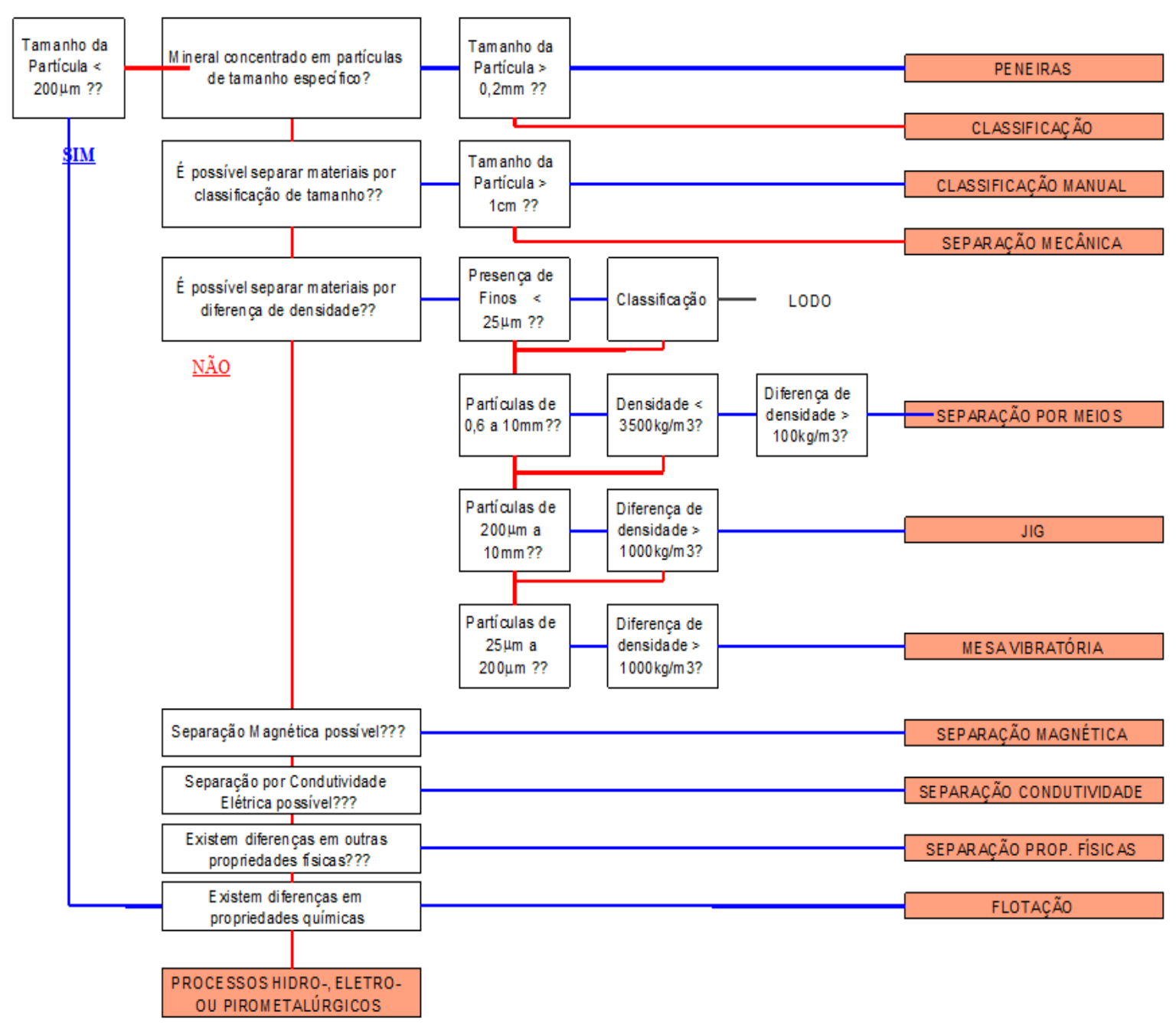

Figura 8 - Esquema geral da etapa de processamento mecânico (Lacor, 2014).

CIMINELLI (2007) alerta ao fato de que estas etapas de preparação são onerosas, especialmente pelo elevado consumo e baixa eficiência energética da cominuição e pelos custos provenientes de processos adicionais como a oxidação sob pressão e a ustulação. Vale ressaltar, entretanto, que estas operações são essenciais ao processo de tratamento dos REEE.

\subsubsection{Processamentos pirometalúrgicos}

Os processos pirometalúrgicos são processos de extração e refino de metais através de reações químicas que ocorrem em altas temperaturas (Gupta, 2003); são temperaturas normalmente acima de $400^{\circ} \mathrm{C}$, suficientemente altas para que tais reações possam ocorrer. 
No caso específico de metais preciosos contidos nos REEE, por não requererem tratamentos prévios dos materiais a serem processados, tampouco rígidos controles sobre o tipo de resíduo e a homogeneidade com que será inserido no reator, a reciclagem e recuperação destes metais preciosos são normalmente feitas por processos pirometalúrgicos (Santanilla, 2012).

Entretanto, os processos pirometalúrgicos tradicionais têm, há tempos, enfrentado resistência frente aos problemas de ordem econômica devido aos altos custos de investimentos, de operação e de manutenção de usinas de tratamento que utilizam predominantemente processos pirometalúrgicos quando comparados aos custos de usinas que utilizam preponderantemente rota hidrometalúrgica. Além disto, um dos principais desafios que os processos pirometalúrgicos enfrentam recai sobre a questão ambiental, dado que estes exigem altas temperaturas nos reatores e que, portanto, são considerados processos energointensivos (Duby, 1977).

Do mesmo modo, o processo de reciclagem e recuperação de metais através de processos pirometalúrgicos recentemente tem enfrentado dificuldades devido ao aparecimento de produtos - principalmente REEE - que apresentam em sua composição elementos metálicos com ligações que não são encontradas na natureza (ou em sua forma natural). Como consequência, muitos destes materiais não são completamente compatíveis com os processos de recuperação de materiais metálicos tradicionais (REUTER et al, 2003).

Com isso, verifica-se que nas últimas décadas as pesquisas e até mesmo as aplicações práticas e industriais de processos hidrometalúrgicos vêm sobrepondo a abordagem pirometalúrgica na recuperação de metais dos resíduos de equipamentos eletroeletrônicos (Cui \& Zhang, 2008).

Assim, nos casos em que é possível utilizar processos alternativos para tratamento e recuperação de metais de interesse, a rota pirometalúrgica é listada como opção financeira e ambientalmente desvantajosa, tendo como seu atual principal rival a hidrometalurgia, principalmente nos casos de operações com menores volumes de resíduos envolvidos. 


\subsubsection{Processamentos biohidrometalúrgicos}

Os processos biohidrometalúrgicos também são chamados de processos de lixiviação bacteriana e podem ser definidos como processos naturais que resultam da ação de um grupo de bactérias (principalmente Acidithiobacillus (Thiobacillus) ferrooxidans) que oxidam os minérios sulfurados para liberar os metais preciosos presentes (Gilbert, Pounds, \& Ice, 1988).

Durante muito tempo, acreditou-se que a dissolução ou a lixiviação de metais a partir de minérios era um processo puramente químico que requeria apenas água e ar atmosférico. A descoberta de bactérias acidófilas (que possuem tolerância e se reproduzem em meio ácido) foi, desta forma, primordial para a definição da lixiviação de metais como um processo catalisado biologicamente (HUTCHINS et al., 1986).

No início da década de 50, os pesquisadores norte-americanos COLMER, TEMPLE e HINKLE (1950) mostraram que o ácido e o ferro contidos na drenagem ácida de uma mina de carvão eram resultantes de uma ação bacteriana sobre os sulfetos de ferro nos veios de carvão desta mina; a esta bactéria eles deram o nome de Acidithiobacillus (Thiobacillus) ferrooxidans (Rosales, Guerrero, \& Sáez, 2001).

Segundo ROSALES et al. (2001), existem algumas variáveis ambientais que têm influência direta no desenvolvimento e no aumento da população de bactérias durante 0 processo de lixiviação bacteriana, e que portanto devem ser constantemente controladas. Algumas destas variáveis são mostradas na Tabela 9 (ROSALES, GUERRERO e SÁEZ, 2001; ROSARIO et al., 2014). 
Tabela 9 - Variáveis ambientais que afetam a performance dos processos biohidrometalúrgicos (ROSALES, GUERRERO e SÁEZ, 2001, em tradução livre; ROSARIO et al., 2014, adaptação do autor).

\begin{tabular}{|c|c|}
\hline Variável ambiental & Descrição \\
\hline $\mathrm{pH}$ & $\begin{array}{l}\text { Em geral os } A \text {. ferrooxidans se desenvolvem bem } \\
\text { em meios ácidos, sendo incapazes de se } \\
\text { desenvolver em soluções contendo Fe(II) sob pH } \\
\text { maior que } 3,0 \text {. } \\
\text { Normalmente, os valores de pH nos quais os } \\
\text { tiobacilos melhor se desenvolvem estão na faixa } \\
\text { enre } 1,5 \text { e } 2,5 \text {. }\end{array}$ \\
\hline Nutrientes & $\begin{array}{l}\text { Como todos os seres vivos, os } A \text {. ferrooxidans } \\
\text { necessitam de fontes de nutrientes para atingir um } \\
\text { nível de desenvolvimento ótimo, dentre os quais } \\
\text { podemos citar alguns como as fontes de amônio, } \\
\text { de fosfato e de enxofre. } \\
\text { O magnésio é necessário para a fixação de gás } \\
\text { carbônico; o fósforo é requerido no metabolismo } \\
\text { energético. }\end{array}$ \\
\hline Oxigênio & $\begin{array}{l}\text { A disponibilidade de oxigênio é um fator crucial } \\
\text { que tem o poder de controlar a taxa de } \\
\text { biolixiviação. } \\
\text { Não há conhecimento de outro elemento oxidante } \\
\text { que possa ser utilizado pelos microrganismos no } \\
\text { processo de lixiviação de metais. }\end{array}$ \\
\hline Luz & $\begin{array}{l}\text { O espectro de luz visível sem quaisquer espécies } \\
\text { de filtros tem efeito inibidor sobre algumas } \\
\text { espécies de Acidithiobacillus. }\end{array}$ \\
\hline Temperatura & $\begin{array}{l}\text { O intervalo de temperaturas no qual se } \\
\text { desenvolvem as bactérias pode normalmente } \\
\text { variar entre } 25^{\circ} \mathrm{C} \text { e } 35^{\circ} \mathrm{C} \text {. }\end{array}$ \\
\hline Concentração de íons & $\begin{array}{l}\text { A concentração de íons metálicos no lixiviado } \\
\text { afeta a performance do processo pois a alta } \\
\text { concentração destes íons, em determinados } \\
\text { casos, pode ser tóxica à colônia de bactérias. } \\
\text { Íons de prata, níquel, ouro, chumbo e zinco, por } \\
\text { exemplo, quando em concentrações elevadas, } \\
\text { prejudicam o processo de biolixiviação por } \\
\text { intoxicação das bactérias. }\end{array}$ \\
\hline $\begin{array}{r}\text { Composição do } \\
\text { material e tamanho de } \\
\text { partícula }\end{array}$ & $\begin{array}{l}\text { A composição do material e o tamanho da } \\
\text { partícula são fatores a serem considerados na } \\
\text { escolha das espécies de microrganismos que } \\
\text { serão utilizados no processo, para que estas } \\
\text { resistam às concentrações de certas substâncias } \\
\text { presentes na solução. }\end{array}$ \\
\hline
\end{tabular}


Inicialmente, estas bactérias encontradas nas drenagens ácidas de minas eram utilizadas basicamente na lixiviação de minérios.

Atualmente, é possível encontrar na literatura diversos autores discutindo o uso de processos biohidrometalúrgicos na recuperação de metais preciosos de resíduos de equipamentos eletroeletrônicos, incluindo as placas de circuito impresso (Santanilla, 2012).

\subsubsection{Processamentos eletrometalúrgicos}

Os processos eletrometalúrgicos consistem na utilização de uma fonte externa de energia para reduzir metais em solução (Popov, Djokic, \& Grgur, 2002).

Eles se distinguem dos processos químicos de oxirredução por apresentarem, necessariamente, ao menos uma etapa onde ocorre transferência de elétrons em um dado substrato, o eletrodo. Não obstante, nas reações eletroquímicas, as etapas de oxidação e redução estão fisicamente separadas: a reação de oxidação ocorre obrigatoriamente na região anódica (ânodo), e a reação de redução ocorre na região catódica (cátodo) (Restivo, 1994).

Em uma célula eletroquímica, o processo se baseia na passagem de uma corrente elétrica através de dois eletrodos imersos em solução. O metal usualmente está contido em uma solução aquosa que foi gerada a partir de processo hidrometalúrgico (Lacor, 2014).

As vantagens dos processos eletrometalúrgicos em relação às outras rotas citadas na recuperação de metais preciosos de REEE são discutidas por HOFFMANN (1992), e podem ser sucintamente resumidas a:

i) Menor quantidade de etapas ao longo do processo de recuperação dos metais;

ii) O concentrado de metais preciosos representa cerca de $95 \%$ a $97 \%$ de todos os metais preciosos encontrados no resíduo, ou seja, a quantidade destes metais no lodo anódico depois da fundição e da eletrólise como refino é muito baixa;

iii) São aplicáveis em todos os tipos de REEE contendo uma camada superficial de metais preciosos sobre um substrato de metal base; 
iv) Os metais de interesse podem ser dissolvidos simultaneamente ou seletivamente, de acordo com o desejado; e

v) O substrato a base de cobre permanece intacto e o eletrólito pode ser reciclado.

Os processos eletrometalúrgicos são também comumente utilizados no refino de metais, processos nos quais os íons metálicos dissolvidos em uma solução são convertidos em depósitos sólidos cristalinos contendo metais com alto grau de pureza (Ribeiro P. M., 2013).

No processo de refino, a célula eletrolítica consiste em um anodo fundido do metal de interesse a ser refinado e um catodo de metal puro (comumente uma chapa de aço inox), ambos colocados em um eletrólito contendo o metal em solução. Íons metálicos são transportados do anodo impuro através da solução até se depositarem no catodo (Hayes, 1985).

\subsubsection{Processamentos hidrometalúrgicos}

Os processos hidrometalúrgicos são processos de extração de metais cuja principal etapa de separação metal-ganga acontece através de reações de dissolução dos minerais contendo os metais de interesse em meio aquoso (Ciminelli, 2007).

A hidrometalurgia por longos períodos foi tratada como a alternativa ambientalmente menos agressiva que os processos pirometalúrgicos tradicionais. Discute-se, entretanto, algumas ressalvas nesta afirmação, especialmente quando se aborda a questão de poluição dos recursos hídricos e do descarte de resíduos sólidos não-inertes - e que portanto carecem de tratamento para poderem ser descartados (Anthony \& Fleet, 1994).

Feitas tais ressalvas, é possível afirmar que as principais vantagens em relação à rota pirometalúrgica se dão nos casos em que os volumes de resíduos a serem tratados são suficientemente pequenos para inviabilizar os investimentos em usinas de tratamento que utilizam a rota pirometalúrgica (Suttill, 1990).

A Figura 9 (Ciminelli, 2007) apresenta um esquema genérico de um típico processo hidrometalúrgico. 


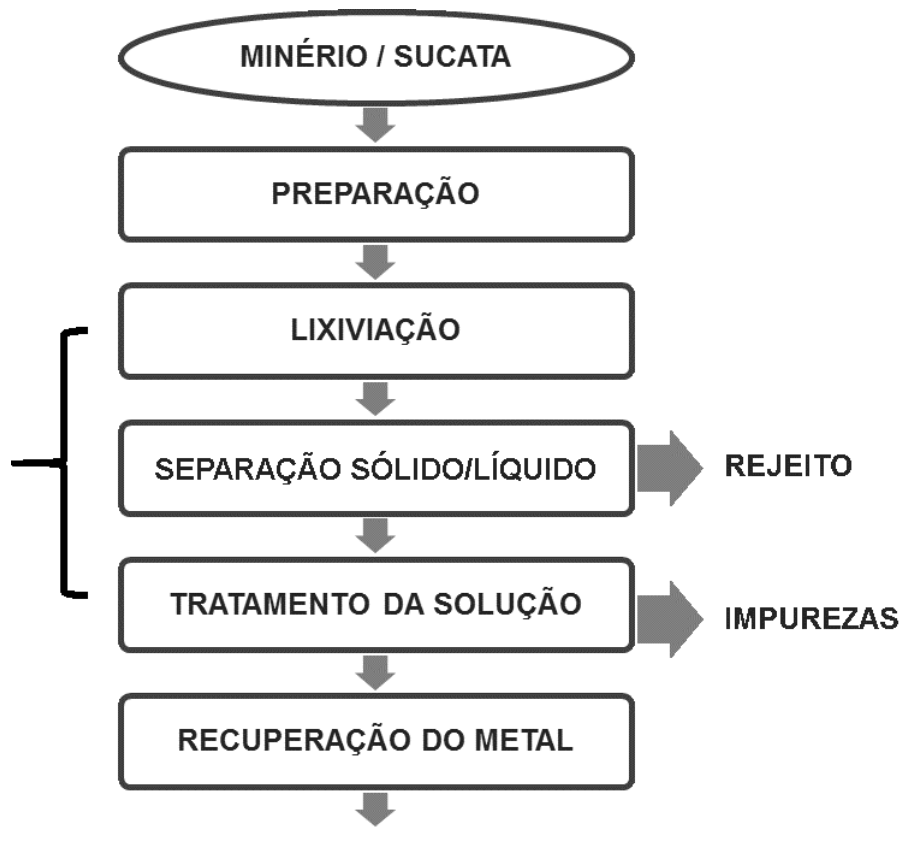

METAL / COMPOSTO METÁLICO

Figura 9 - Esquema genérico de um típico processo hidrometalúrgico (Ciminelli, 2007).

A hidrometalurgia é uma das principais formas de tratamento e recuperação de metais preciosos e de interesse econômico da atualidade.

Nas últimas décadas, o processamento de metais através de técnicas de hidrometalurgia tem se tornado um método consagrado na recuperação de metais de matérias primas ou a partir de resíduos (Souza, Oliveira, \& Tenório, 2001).

Dada sua relevância, a rota hidrometalúrgica será discutida com mais detalhes no item 2.7 a seguir.

\subsection{A ROTA HIDROMETALÚRGICA PARA TRATAMENTO DE REEE}

Conforme mostrado na Figura 9 (página 53), a rota hidrometalúrgica mais comumente utilizada para tratamento de resíduos de equipamentos eletroeletrônicos conta basicamente com as seguintes etapas de processamento:

i) Preparação dos resíduos;

ii) Lixiviação;

iii) Separação sólido-líquido;

iv) Tratamento da solução; e finalmente

v) Recuperação do metal de interesse. 
Diversos trabalhos sobre tratamento e reciclagem de REEE e recuperação de metais destes resíduos utilizando vias hidrometalúrgicas que contemplam os processos citados podem ser encontrados na literatura científica internacional.

GOOSEY e KELLNER (2003) realizaram um trabalho sobre a reciclagem de placas de circuito impresso, encorajados pelas então recentes legislações norteamericanas e europeias que tratam dos resíduos de equipamentos eletroeletrônicos, no qual comentam sobre as alternativas existentes à época - entre elas a rota hidrometalúrgica em conjunto com metodologias de tratamento mecânico - em busca de soluções para o problema mundial do REEE.

Sob uma abordagem semelhante, GRAMATYKA, NOWOSIELSKI e SAKIEWICZ (2007) publicaram um trabalho sobre o descarte do REEE nos países da União Europeia e seus respectivos impactos no meio ambiente, na saúde humana e na economia. Neste trabalho foram comentadas as vantagens do tratamento destes resíduos através do uso de rotas hidrometalúrgicas em detrimento dos tradicionais processos pirometalúrgicos.

DALRYMPLE et al. (2007) realizaram um estudo patrocinado pelo Departamento de Meio Ambiente, Alimentos e Assuntos Rurais do Reino Unido sobre a composição dos REEE, no qual abordam também as tecnologias disponíveis para tratamento destes rejeitos - incluindo os métodos de tratamento através de rotas hidrometalúrgicas - e pesquisas nesta área, que fazem parte de um projeto do governo para desenvolver soluções para o problema do volume crescente de REEE.

PARK e FRAY (2009) publicaram os resultados de um estudo sobre a recuperação de metais preciosos de placas de circuito impresso através do uso de água régia como agente lixiviante, nos quais foram atingidos cerca de $98 \%$ de recuperação de prata, $93 \%$ de paládio, e $97 \%$ de ouro, este através de nanopartículas, respeitadas as condições dos ensaios.

ROCHETTI et al. (2013) realizaram um estudo sobre a análise do ciclo de vida do tratamento de REEE utilizando rota hidrometalúrgica através de um protótipo de usina portátil de recuperação de metais de interesse econômico, tais como zinco, cobre, lítio, ouro e prata, obtendo resultados positivos quando balizados pelos critérios europeus de potenciais de emissão de gases de efeito estufa.

É possível ainda encontrar diversos trabalhos abordando o tema de recuperação de metais de REEE por rotas hidrometalúrgicas na literatura científica 
brasileira, realizados por pesquisadores de laboratórios e de centros de pesquisas em universidades e, com menos frequência mas ainda relevante, nas indústrias.

TAKAHASHI (2007) pesquisou sobre a recuperação de cobalto de baterias de íons de lítio de telefones celulares obsoletos através de lixiviação ácida em diferentes condições, obtendo eficiência global na etapa de extração de $94 \%$ de recuperação do cobalto existente nas baterias e de até 98\% quando submetido ao processo de reextração; nestas condições utilizou-se ácido nítrico misturado a ácido sulfúrico com adições de peróxido de hidrogênio.

CASTRO e MARTINS (2009) realizaram um estudo sobre a extração e a recuperação de estanho e cobre de placas de circuito impresso de computadores obsoletos através da lixiviação seguida de precipitação destes metais, com resultados da lixiviação na ordem de $98 \%$ de recuperação de estanho e 93\% de recuperação de cobre.

MORAES (2011) realizou um estudo sobre a recuperação de metais de placas de circuito impresso de telefones celulares obsoletos utilizando rota hidrometalúrgica - além de pré-processamento mecânico -, obtendo resultados de recuperação de cobre de cerca de $99 \%$ através da lixiviação com ácido sulfúrico em meio oxidante a $75^{\circ} \mathrm{C}$.

PETTER et al. (2012) publicaram uma pesquisa sobre o estudo de lixiviantes alternativos para a extração de metais de placas de circuito impresso de telefones celulares descartados considerando a rota hidrometalúrgica, com resultados favoráveis para o uso de ácido nítrico, dadas as condições específicas dos ensaios realizados.

CALDAS et al. (2014) realizaram um estudo sobre a extração dos metais prata e estanho de soldas presentes nas placas de circuito impresso através da digestão ácida em água-régia e ácido nítrico em temperatura ambiente, alcançando resultados de recuperação de 90,3\% de prata utilizando ácido nítrico e de 99,9\% de estanho utilizando água régia.

LOUREIRO et al. (2014) publicaram um estudo sobre a classificação e caracterização de placas de circuito impresso e seus impactos sobre a eficiência dos processos de extração dos metais presentes via rota hidrometalúrgica, com uso de água régia e ácido nítrico. 
A rota hidrometalúrgica para tratamento de REEE é, portanto, uma metodologia consolidada e amplamente estudada, porém com novas pesquisas sendo lançadas todos os anos ao redor do mundo, criando expectativas de avanços nos processos existentes e de novas tecnologias.

Considerando a importância de cada etapa no processo de tratamento de REEE utilizando rota hidrometalúrgica, cada uma delas será abordada separadamente neste trabalho.

\subsubsection{Preparação dos resíduos}

Independentemente da rota escolhida para o tratamento e reciclagem dos REEE, a caracterização e o preparo dos resíduos são etapas fundamentais para determinar os tipos de materiais que se deseja recuperar (Massucatto, Tenório, \& Espinosa, 2013).

CORREA, TENORIO E ESPINOSA (2014) realizaram um estudo sobre o processamento mecânico de placas-mãe de computadores pessoais descartados, mostrando a importância da etapa de preparação dos resíduos para garantir a eficácia das etapas químicas posteriores e que fazem parte da rota hidrometalúrgica de tratamento de REEE.

Por preparação entende-se processamento físico do material a ser tratado, em uma etapa anterior aos processos químicos e metalúrgicos aos quais estes materiais serão submetidos.

A etapa de preparação consiste em uma ou mais operações unitárias, comumente semelhantes àquelas utilizadas no processamento de minérios.

Estas operações unitárias podem ser classificadas como (Luz \& Lins, 2004):

- Cominuição (britagem e moagem);

- Peneiramento (separação por tamanhos) e classificação (ciclonagem ou classificador espiral);

- Concentração (gravimétrica, magnética, eletrostática, flotação);

- Desaguamento (espessamento e filtragem);

- Secagem (secador rotativo, spray dryer, secador de leito fludizado);

- Disposição de rejeito. 
Como as operações no caso específico de REEE são normalmente realizadas a seco, as últimas etapas de desaguamento e secagem naturalmente não são aplicáveis a estes casos.

\subsubsection{Desmantelamento manual: um pré-processamento}

Quando necessário, é feito um desmantelamento manual - ou com o auxílio de ferramentas simples como chaves de fenda e alicates, conforme pode ser visto na fotografia da Figura 10 (CEDIR, 2011) - das peças que se desprendem com facilidade do resíduo, com o intuito de melhorar o controle e a homogeneidade das amostras a serem tratadas.

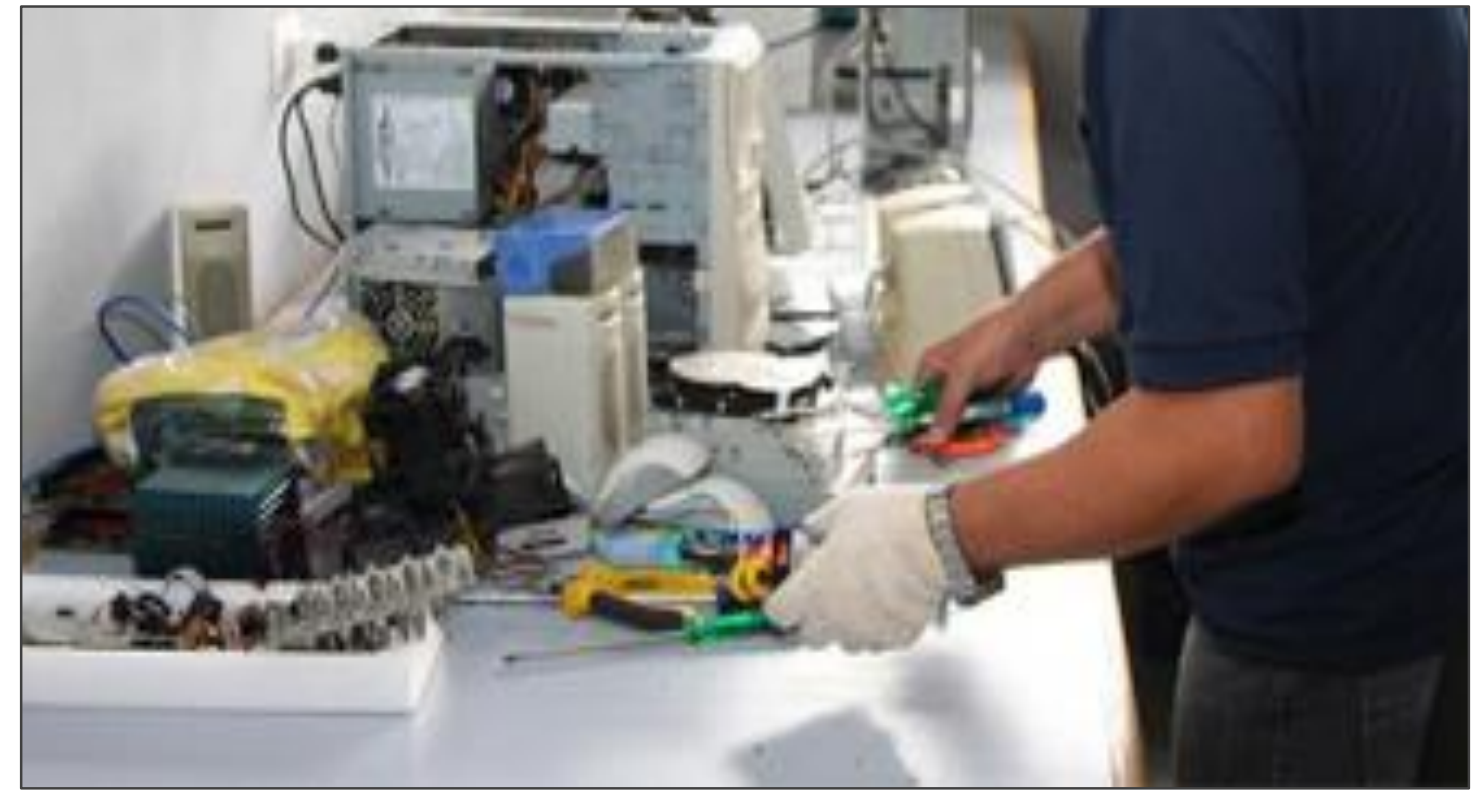

Figura 10 - 0 desmantelamento manual de placas de circuito impresso traz diversos benefícios ao processo de tratamento dos REEE (CEDIR, 2011).

Além disto, as principais vantagens do processo de desmantelamento manual são possibilitar (Li \& Zeng, 2012):

i) A remoção de componentes perigosos, que ofereçam risco de explosão ou contaminação;

ii) O reaproveitamento de componentes que se encontram em condições de uso;

iii) A separação de componentes valiosos; 
iv) A remoção de componentes que requerem tratamentos especiais como baterias e capacitores.

ABRANTES (2009), SANTANILLA (2012), YAMANE (2012), CORREA, TENÓRIO e ESPINOSA (2014) e SILVA et al. (2014) em seus respectivos trabalhos com placas de circuito impresso realizaram a separação manual de alguns componentes afixados à placa, como processadores, chips, pentes de memória, resfriadores, ventiladores, dissipadores de calor e cabos. Com isto, segundo os autores, aumentou-se a eficiência dos processos conseguintes - inclusive evitando problemas de travamento dos equipamentos - e se aperfeiçoou a questão da homogeneidade das amostras.

Na sequência, passa-se à etapa de cominuição através da moagem.

\subsubsection{Cominuição através da moagem dos REEE}

A etapa fundamental para a viabilidade do tratamento de resíduos através da rota hidrometalúrgica é a redução das dimensões do material a ser tratado, ou a redução do tamanho das partículas, que no caso específico das placas de circuito impresso é alcançado através da moagem.

A cominuição possibilita que o material (amostra) tenha mais superfície exposta em contato com os reagentes utilizados nas etapas de processamento químico. A redução do tamanho de partícula determina diretamente a eficiência do processo de recuperação dos metais destes resíduos (TAN et al., 2011).

Existem no mercado inúmeros tipos diferentes de moinhos, todos com a mesma função de diminuir o tamanho de partículas. No caso específico de placas de circuito impresso, entretanto, os tipos mais frequentemente utilizados e encontrados na literatura são os moinhos de facas (VEIT et al., 2008), de bolas (Das, Vidyadhar, \& Mehrotra, 2009), de impacto (YOO et al., 2009) e de martelos (YAMANE et al., 2011), ou a combinação de alguns deles (CORREA, 2015; PETTER, VEIT e BERNARDES, 2014).

Ao término deste processo, segue-se à etapa de peneiramento e classificação. 


\subsubsection{Peneiramento e classificação}

O peneiramento e a classificação têm como objetivo a separação de um dado material em duas ou mais frações com partículas de tamanhos distintos. Enquanto no peneiramento a separação ocorre de acordo com o tamanho geométrico das partículas, na classificação a separação é realizada tomando-se como base a velocidade com que os grãos atravessam um meio fluido - geralmente água (Carrisso \& Correira, 2004).

Para o caso específico de tratamento de REEE, estas etapas não são mandatórias. De fato, o uso destas técnicas não são comumente encontrados nos trabalhos publicados na literatura sobre recuperação de metais dos REEE, senão em casos específicos onde se deseja avaliar as frações de acordo com os tamanhos dos grãos, como é o caso, por exemplo, de MASSUCATTO, TENÓRIO E ESPINOSA (2013).

Na sequência, tem-se a etapa de concentração das partículas.

\subsubsection{Concentração das partículas}

A separação dos materiais pode ser feita com base nas características visuais, de densidade, magnéticas ou eletrostáticas das partículas (Gramatyka, Nowosielski, \& Sakiewicz, 2007).

A concentração gravimétrica se baseia na diferença de densidade entre as partículas presentes na amostra, utilizando-se de um meio fluido (água ou ar) para realizar a separação. Neste processo, são comumente utilizados equipamentos como jigues, mesas vibratórias, espirais, cones e sluices. Analogamente, a separação por meio denso possui o mesmo princípio da concentração gravimétrica, com a diferença que envolve um meio fluido com valor de densidade intermediário entre os dois componentes que se deseja separar (Dutra, 2006).

A separação magnética se baseia na susceptibilidade magnética dos materiais a serem processados, enquanto o método eletrostático considera a condutividade elétrica destes materiais como a propriedade básica de separação (Sampaio \& Luz, Separação Magnética e Eletrostática, 2004).

A atração magnética de um dado material varia de acordo com a sua composição química, ou ainda com o índice de impurezas nele contidos. A 
propriedade dos materiais que determina as suas respostas a um campo magnético é a denominada Susceptibilidade Magnética. Com base nesta propriedade, os materiais são classificados naqueles que são atraídos pelo campo magnético e naqueles que são repelidos por esse campo. Os detalhes sobre cada tipo de material são discutidos na Tabela 10 (Sampaio, França, \& Luz, Ensaios de Separação Magnética e Eletrostática, 2007).

\begin{tabular}{|c|c|}
\hline $\begin{array}{r}\text { Classificação do } \\
\text { material }\end{array}$ & Descrição \\
\hline Ferromagnéticos & $\begin{array}{l}\text { São fortemente atraídos pelo ímã comum. O } \\
\text { exemplo mais conhecido é a magnetita }\left(\mathrm{Fe}_{3} \mathrm{O}_{4}\right) \text {. }\end{array}$ \\
\hline Paramagnéticos & $\begin{array}{l}\text { São fracamente atraídos pelo ímã comum. O } \\
\text { exemplo clássico é a hematita }\left(\mathrm{Fe}_{2} \mathrm{O}_{3}\right) \text {. } \\
\text { Possuem permeabilidade magnética mais elevada } \\
\text { que a do meio circundante (usualmente água ou ar) } \\
\text { e concentram um elevado número de linhas de } \\
\text { indução provenientes do campo externo. }\end{array}$ \\
\hline Diamagnéticos & $\begin{array}{l}\text { Possuem susceptibilidade magnética negativa e, } \\
\text { portanto, são repelidos quando submetidos a um } \\
\text { campo magnético. Exemplos: quartzo, magnesita, } \\
\text { calcita, barita e fluorita. } \\
\text { Possuem permeabilidade magnética mais baixa } \\
\text { que a do meio circundante (usualmente água ou } \\
\text { ar). O efeito diamagnético é geralmente menor que } \\
\text { o correspondente efeito de atração dos minerais } \\
\text { paramagnéticos. }\end{array}$ \\
\hline
\end{tabular}

A separação eletrostática se baseia no princípio de que os materiais podem receber cargas superficiais (positivas ou negativas, dependendo das condições de eletrização) quando submetidos a um campo elétrico. Uma vez carregadas, as partículas percorrem trajetórias distintas ao atravessarem uma determinada região do espaço onde haja um campo elétrico (Sampaio, França, \& Luz, Ensaios de Separação Magnética e Eletrostática, 2007). Considerando que todo material possui um determinado grau de condutividade, o processo de separação eletrostática usará, como princípio, a diferença entre a condutividade elétrica ou cargas superficiais existentes nas diversas espécies a serem separadas (Venkatraman, Knoll, \& Lawver, 2006). 
Existem, entretanto, controvérsias quanto à necessidade de utilização destas operações de concentração e separação das partículas no tratamento de resíduos eletrônicos. Na literatura científica é possível encontrar trabalhos que recorrem à rota hidrometalúrgica realizados sem o uso destas etapas, assim como é comum encontrar publicações nas quais foram utilizados os recursos de separação magnética e eletrostática.

YAMANE et al. (2011) realizaram um trabalho sobre a reciclagem de REEE no qual foram caracterizadas as placas de circuito impresso de resíduos de telefones celulares e computadores pessoais. Os autores concluíram que a fração magnética representa cerca de $18 \%$ em peso das $\mathrm{PCl}$ (compostos basicamente por ferro e níquel).

Além disto, BAKAS et al. (2014) descrevem uma planta de pré-processamento para reciclagem de REEE na qual, a determinada altura após a etapa de cominuição por moinhos de martelos, os resíduos são submetidos a tratamentos em equipamentos de separação magnética e por corrente de Foucault, por considerarem ambas etapas essenciais à recuperação dos metais de interesse.

Por fim, CORREA (2015) apresentou, em seu trabalho de recuperação de metais contidos em placas-mãe de computadores pessoais descartados, a recomendação de se realizar a separação magnética dos resíduos cominuídos quando há o objetivo de dissolver o cobre em etapas posteriores de lixiviação, uma vez que o ferro presente interfere na eficiência da lixiviação do cobre.

Por outro lado, PETTER, VEIT e BERNARDES (2014) realizaram um estudo sobre a recuperação de ouro e prata de $\mathrm{PCl}$ apenas com a cominuição dos materiais como tratamento preliminar aos ensaios de lixiviação, obtendo resultados globais da ordem de $100 \%$ de recuperação de prata e $60 \%$ de recuperação de ouro.

De forma análoga, ABRANTES (2009), em seu trabalho de reciclagem de placas de circuito impresso, logo após a etapa de cominuição das amostras, não identificou a necessidade de recorrer a processos de separação de partículas, chegando à conclusão de que dadas as condições específicas de seu trabalho, os processos de fragmentação aplicados geravam resultados satisfatórios às necessidades de seu trabalho.

Não há, desta forma, um consenso quanto à necessidade de utilização destas etapas de separação na rota hidrometalúrgica de reciclagem de REEE. Assim, cada 
situação específica deve ser analisada levando em conta os critérios de eficácia do processo de separação e de eficiência na recuperação dos elementos de interesse ao término do processo.

\subsubsection{Lixiviação}

A lixiviação é a primeira etapa do processamento hidrometalúrgico, e consiste na dissolução dos metais presentes nas amostras para uma solução aquosa.

A reação de lixiviação está diretamente relacionada com os parâmetros de potencial de oxirredução $\left(E_{h}\right)$ e o pH de uma dada solução (Correa M. M., 2015).

O potencial de oxirredução é uma referência para as taxas de oxidação de determinadas espécies, como o ferro por exemplo, e representa a tendência da solução em sofrer redução ou oxidação, ou ainda a sua capacidade de capturar ou liberar elétrons (Peixoto, Sobral, \& Oliveira, 2009).

A representação gráfica da relação entre o potencial de oxirredução e o pH é conhecida como Diagrama de Pourbaix, assunto que será abordado no subitem 2.7.2.1 adiante.

Segundo ZHANG et al. (2012), através da lixiviação extraem-se os constituintes solúveis de um sólido pelo contato com um solvente, que no caso de metais preciosos os agentes lixiviantes mais utilizados são os cianetos, os haletos, as tioureias e os tiossulfatos.

No caso de tratamento de REEE através de rota hidrometalúrgica, os agentes lixiviantes mais comumente utilizados em trabalhos publicados na literatura científica são o ácido nítrico $\left(\mathrm{HNO}_{3}\right)$, o ácido sulfúrico $\left(\mathrm{H}_{2} \mathrm{SO}_{4}\right)$ e o ácido clorídrico $(\mathrm{HCl})$, sendo que a escolha do agente lixiviante depende de cada caso específico e principalmente dos elementos que se procura extrair.

BAS, DEVECI e YAZICI (2014) utilizaram ácido nítrico para extrair cobre e prata de $\mathrm{PCl}$ de televisores, controlando os parâmetros de concentração do ácido, da temperatura dos ensaios e dos tamanhos das partículas da amostra. Concluíram que o fator que mais influencia a eficiência do processo de lixiviação destes dois metais é a concentração do ácido nítrico, e que apesar dos fatores temperatura e tamanho de partícula também influenciarem a cinética da reação, os efeitos das interações destes parâmetros é insignificante. Os autores concluíram também que a cinética desta 
reação é controlada quimicamente, com a cinética consistente com o modelo de núcleo não-reagido e energia de ativação de $38,6 \mathrm{~kJ} / \mathrm{mol}$. Ao final, obtiveram extrações de cobre entre $88,5 \%$ a 99,9\% com ácido nítrico às concentrações de 2 e $5 \mathrm{~mol} / \mathrm{L}$ respectivamente; e $14 \%$ a $68 \%$ de recuperação de prata às concentrações de 1 e 5 $\mathrm{mol} / \mathrm{L}$, respectivamente.

HAVLIK et al. (2010) realizaram um estudo da lixiviação de cobre e estanho de $\mathrm{PCl}$ com a utilização de ácido clorídrico na concentração de $1 \mathrm{~mol} / \mathrm{L}$ à temperatura de $80^{\circ} \mathrm{C}$ por 180 minutos, no qual compararam os resultados das porcentagem de recuperação destes metais quando as amostras são submetidas a um pré-tratamento térmico ou à pirólise, em relação às amostras submetidas ao processo de lixiviação ácida sem tratamentos preliminares, considerando que em todos os ensaios as amostras passaram previamente por tratamento mecânico de moagem. Os autores concluíram que o tratamento térmico aumenta a eficiência do processo lixiviação com a utilização de ácido clorídrico na extração de cobre; no caso do estanho, esta eficiência aumenta quando utilizado o processo de pré-tratamento por pirólise.

CALDAS et al. (2015) analisaram a extração de diversos metais presentes em $\mathrm{PCl}$ - sendo o ferro um dos elementos analisados - e propuseram uma rota hidrometalúrgica para recuperação de prata e cobre através de um ensaio de lixiviação utilizando ácido sulfúrico na concentração de $1 \mathrm{~mol} / \mathrm{L}$ a $75^{\circ} \mathrm{C}$ por 18 horas, seguido de ensaio com ácido sulfúrico e peróxido de hidrogênio 130 volumes na relação sólido:líquido de 1:10, a $75^{\circ} \mathrm{C}$ pelo período de 6 horas, e por fim um ensaio com ácido nítrico à concentração de $10 \mathrm{~mol} / \mathrm{L}$ na relação sólido:líquido de 1:20, à temperatura ambiente por 2 horas. Como resultados, não obtiveram quantidades significativas de prata nem de cobre do processo de lixiviação ácida, mas recuperaram $36,1 \%$ em massa do ferro; na lixiviação ácida em meio oxidante, extraíram $41 \%$ da prata, $62,7 \%$ do cobre e $63,9 \%$ do ferro; na lixiviação com ácido nítrico, recuperaram $55,6 \%$ da prata e $37,3 \%$ do cobre, ao passo que $100 \%$ do ferro presentes nas $\mathrm{PCl}$ já haviam sido extraídos nos processos anteriores.

CORREA (2015) realizou um trabalho sobre a separação de metais nãoferrosos de $\mathrm{PCl}$ no qual, resumidamente, as amostras de placas-mãe passam por separação magnética e então ambas as frações magnética e não-magnética são submetidas a processamento hidrometalúrgico, com lixiviação através do uso de ácido sulfúrico com concentrações de $1 \mathrm{~mol} / \mathrm{L}$ e $2 \mathrm{~mol} / \mathrm{L}$, às temperaturas de $25^{\circ} \mathrm{C}, 50^{\circ} \mathrm{C}$ e 
$75^{\circ} \mathrm{C}$, além de adições de peróxido de hidrogênio $30 \%$ em volume a cada 30 minutos de ensaio, feitas com o intuito de aumentar os potenciais das reações presentes.

Desta forma, considerou-se as reações de dissolução de metais descritas pelas Equação 2, Equação 3, Equação 4, Equação 5 e Equação 6 abaixo (BIRLOAGA et al., 2013).

$$
\begin{array}{lr}
\mathrm{Cu}^{0}+\mathrm{H}_{2} \mathrm{SO}_{4}+\mathrm{H}_{2} \mathrm{O}_{2} \rightarrow \mathrm{CuSO}_{4}+2 \mathrm{H}_{2} \mathrm{O} ; \Delta G^{0}=-77,941 \mathrm{kcal} / \mathrm{mol} & \text { Equação } 2 \\
\mathrm{Zn}^{0}+\mathrm{H}_{2} \mathrm{SO}_{4}+\mathrm{H}_{2} \mathrm{O}_{2} \rightarrow \mathrm{ZnSO}_{4}+2 \mathrm{H}_{2} \mathrm{O} ; \Delta G^{0}=-127,965 \mathrm{kcal} / \mathrm{mol} & \text { Equação 3 } \\
\mathrm{Sn}^{0}+\mathrm{H}_{2} \mathrm{SO}_{4}+\mathrm{H}_{2} \mathrm{O}_{2} \rightarrow \mathrm{SnSO}_{4}+2 \mathrm{H}_{2} \mathrm{O} ; \Delta G^{0}=-136,895 \mathrm{kcal} / \mathrm{mol} & \text { Equação } 4 \\
\mathrm{Fe}^{0}+\mathrm{H}_{2} \mathrm{SO}_{4}+\mathrm{H}_{2} \mathrm{O}_{2} \rightarrow \mathrm{FeSO}_{4}+2 \mathrm{H}_{2} \mathrm{O} ; \Delta G^{0}=-115,847 \mathrm{kcal} / \mathrm{mol} & \text { Equação } 5 \\
\mathrm{Ni}^{0}+\mathrm{H}_{2} \mathrm{SO}_{4}+\mathrm{H}_{2} \mathrm{O}_{2} \rightarrow \mathrm{NiSO}_{4}+2 \mathrm{H}_{2} \mathrm{O} ; \Delta G^{0}=-101,244 \mathrm{kcal} / \mathrm{mol} & \text { Equação } 6
\end{array}
$$

No caso do ferro presente nas amostras, obteve-se lixiviações de cerca de $90 \%$ após 6 horas de processamento a 75ํㅡ, com o uso de ácido sulfúrico na concentração de $1 \mathrm{~mol} / \mathrm{L}$; e $93 \%$ nas mesmas condições, mas com ácido sulfúrico na concentração de 2mol/L (Correa M. M., 2015).

Em todos os casos anteriormente citados, foi determinante o entendimento da influência do potencial de oxirredução e do pH na seleção do agente lixiviante e na escolha da sua concentração, sob determinadas condições de temperatura, na eficácia do processo de lixiviação de determinados metais.

\subsubsection{Diagramas de Pourbaix}

O Diagrama de Pourbaix (Pourbaix, Atlas of Electrochemical Equilibria in Aqueous Solutions, 1966), também conhecido como diagrama $E_{h} / \mathrm{pH}$, é uma representação gráfica do potencial de oxirredução em função do $\mathrm{pH}$ para um determinado metal a uma dada temperatura, levando em conta os equilíbrios químicos e eletroquímicos, e que define os campos de estabilidade para o eletrólito, o metal e os compostos presentes (óxidos, hidróxidos). Tais diagramas são construídos tendo como base os cálculos da equação de Nernst e as constantes de equilíbrio dos diferentes compostos metálicos (Portero, 2011). 
Estes diagramas apresentam regiões claramente delimitadas nas quais se preveem os comportamentos dos metais, e logo se serão encontrados na forma solubilizada ou insolubilizada. Um diagrama genérico pode ser visto na Figura 11 (Jackson, 1986).

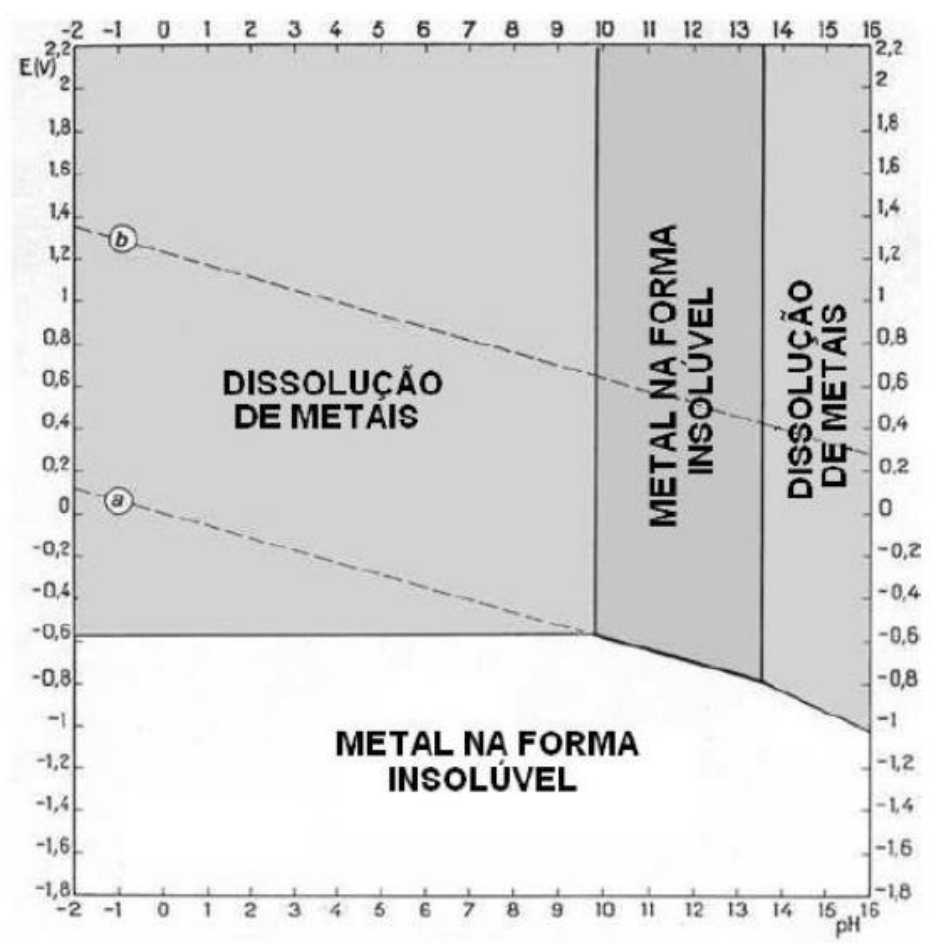

Figura 11 - Esquema simplificado do Diagrama de Pourbaix para metais (POURBAIX,1966; JACKSON, 1986).

A Figura 12 apresenta como exemplo o diagrama de equilíbrio potencial-pH para o sistema ferro-água a 25ํㅡ (POURBAIX e ZOUBOV, 1963; adaptação do autor). 


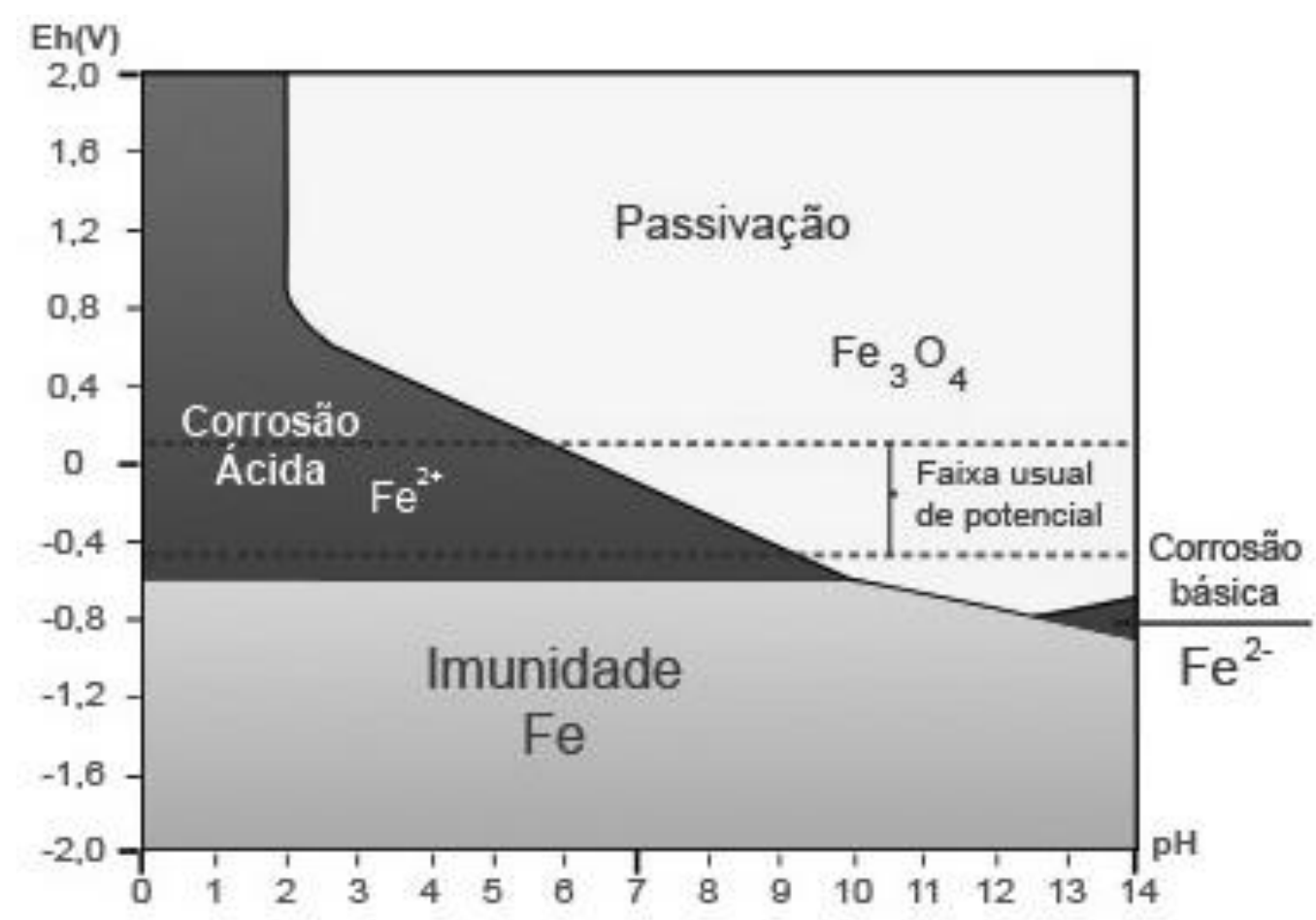

Figura 12 - Diagrama de equilíbrio potencial $\left(\mathrm{E}_{\mathrm{h}}\right)$ / $\mathrm{pH}$ para o sistema ferro-água à temperatura de 25Cㅡ (POURBAIX e ZOUBOV, 1963; adaptação do autor).

Os diagramas de Pourbaix são muito úteis em aplicações em que se deseja prever o comportamento de um determinado metal quando este é submetido a uma condição específica de pH, temperatura e potencial de oxirredução; desta forma, são muito utilizados nos ensaios de lixiviação de metais para sua extração e posterior recuperação, além de auxiliar na determinação do agente lixiviante a ser utilizado.

\subsubsection{Ensaios de digestão em água-régia}

Água régia é uma mistura de ácido nítrico $\left(\mathrm{HNO}_{3}\right)$ com ácido clorídrico $(\mathrm{HCl})$ geralmente na proporção de 1:3 (Cecon, 2012).

A digestão em água-régia é utilizada como forma de extração de determinados metais presentes nos REEE. É o caso, por exemplo, do ouro, cujas reações químicas que ocorrem no processo de lixiviação com água régia podem ser observadas na Equação 7 e na Equação 8 (Vogel, 1979). 


$$
\begin{array}{cc}
2 \cdot \mathrm{HNO}_{3(a q)}+6 \cdot \mathrm{HCl}_{(a q)} \rightarrow 2 \cdot \mathrm{NO}_{(g)}+4 \cdot \mathrm{H}_{2} \mathrm{O}_{(l)}+3 \cdot \mathrm{Cl}_{2(g)} & \text { Equação 7 } \\
\mathrm{Au}_{(s)}+4 \cdot \mathrm{H}_{(a q)}^{+}+\mathrm{NO}_{3(a q)}^{-}+4 \cdot \mathrm{Cl}_{(a q)}^{-} \rightarrow \mathrm{AuCl}_{4(a q)}^{-}+\mathrm{NO} \mathrm{O}_{(g)}+2 \cdot \mathrm{H}_{2} \mathrm{O}_{(l)} & \text { Equação 8 }
\end{array}
$$

SHENG e ETSELL (2007) realizaram um estudo sobre a recuperação de ouro de $\mathrm{PCl}$ de microcomputadores através da lixiviação com o uso de água régia, controlando o tempo e a temperatura dos ensaios. Como resultado, concluíram que a proporção ótima da quantidade de reagente pela massa de material era de $2 \mathrm{~mL}$ de água régia por grama de $\mathrm{PCl}$; concluíram também que o aumento na velocidade de dissolução das amostras era proporcional ao aumento da temperatura.

De acordo com RAMUNNO (2015), devido ao poder de dissolução de diversos metais, a água régia também é frequentemente utilizada em processos de caracterização de REEE, como por exemplo nos trabalhos de MORAES (2011) e de YAMANE (2012).

SILVA et al. (2014) utilizaram a água régia na caracterização de placas de circuito impresso de microcomputadores obsoletos, expondo as amostras pelo período de 24 horas à temperatura ambiente. Os resultados dos seus ensaios indicaram que a fração de metais nestas $\mathrm{PCl}$ representa cerca de $35,5 \%$ da massa das amostras.

De forma análoga, CORREA (2015) utilizou digestão em água régia como meio para caracterizar placas-mãe de microcomputadores descartados, obtendo solubilização da ordem de $36 \%$ da massa das amostras. Seu trabalho, entretanto, estendeu-se na análise das frações magnéticas e não-magnéticas de suas amostras, cujos resultados apontaram $7,8 \%$ e $28 \%$ de extração de metais destas frações, respectivamente.

Com o intuito de quantificar os elementos presentes nos REEE principalmente os elementos metálicos -, AROLD et al. (2014) realizaram um estudo analisando a quantidade de determinados elementos como prata, alumínio, ouro, estanho, zinco, chumbo, níquel, cobre e ferro de $\mathrm{PCl}$ que passaram por processo de separação magnética. Os resultados indicaram que há apenas $0,1 \%$ em massa de ferro presente na fração não-magnética da amostra, enquanto o cobre representou 15,2\% desta fração; a quantidade de metais na fração não-magnética representa, no caso específico deste trabalho, $21,3 \%$ em massa do total da amostra. 


\subsection{CINÉTICA DO PROCESSO DE LIXIVIAÇÃO}

A cinética química estuda as velocidades com que as reações químicas ocorrem e os fatores que direta ou indiretamente influenciam as velocidades destas reações. A cinética química baseia-se nos processos químicos empíricos e experimentais para criar modelos matemáticos da cinética das reações e equações diferenciais que as representam (Atkins \& Jones, 2009).

As reações químicas podem ser classificadas como sistemas homogêneos (quanto ocorrem em apenas uma fase) ou sistemas heterogêneos (quando duas ou mais fases estão envolvidas na reação) (Levenspiel, 1972).

As reações que ocorrem nos processos de lixiviação ácida, por exemplo, são consideradas sistemas heterogêneos, que ocorrem em meio aquoso e se processam em um sistema sólido-líquido (Ramunno, 2015).

Segundo BURKIN (2001), as reações de lixiviação podem ser divididas nas seguintes etapas:

i) Transporte dos reagentes na solução para a interface sólido-líquido;

ii) Adsorção dos reagentes na superfície;

iii) Reações químicas na superfície;

iv) Dessorção dos produtos solúveis da reação;

v) Transporte dos produtos solúveis para longe da interface sólidolíquido.

No caso dos sistemas heterogêneos, existe uma dificuldade em se obter expressões matemáticas que representem a cinética das reações devido à complexidade do sistema quando são considerados todos os parâmetros das etapas controladas por transporte de massa e por reação química. Desta forma, considerase, para efeitos de estudo, apenas a etapa mais lenta do sistema como etapa controladora da cinética da reação, que é então analisada isoladamente. Esta consideração, por fim, simplifica a obtenção das expressões matemáticas que representam o mecanismo controlador da cinética da reação em questão (Ramunno, 2015). 


\subsubsection{Cinética de reações heterogêneas}

As reações químicas heterogêneas são aquelas em que um fluido (gasoso ou líquido) entra em contato com uma partícula sólida, gerando então um produto, que pode ser fluido, sólido ou ambos. Tais reações podem ser representadas pela Equação 9, pela Equação 10 e pela Equação 11 (Levenspiel, 1972).

$$
\begin{array}{cc}
A(\text { fluido })+b B(\text { sólido }) \rightarrow \text { produtos fluidos } & \text { Equação } 9 \\
A(\text { fluido })+b B(\text { sólido }) \rightarrow \text { produtos sólidos } & \text { Equação } 10 \\
A(\text { fluido })+b B(\text { sólido }) \rightarrow \text { produtos fluidos e sólidos } & \text { Equação } 11
\end{array}
$$

Segundo LEVENSPIEL (1972), nas reações heterogêneas as partículas sólidas ao reagir com o fluido podem assumir os seguintes comportamentos:

a) O tamanho das partículas continua inalterado ao longo da reação, conforme ilustrado na Figura 13, devido à grande quantidade de impurezas presentes que não reagem ou devido à formação de um subproduto da reação que adere à superfície da partícula.

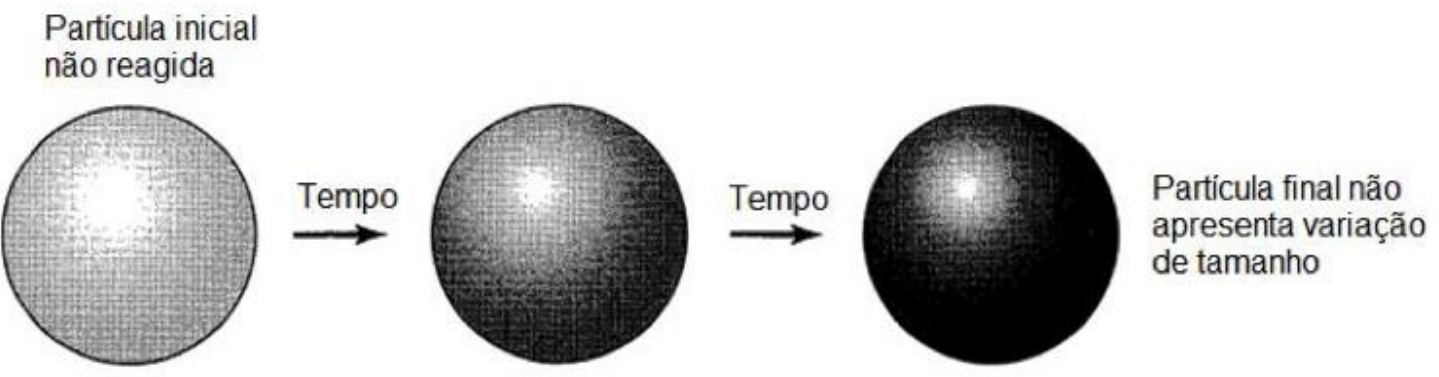

Figura 13 - Comportamento das partículas nas reações heterogêneas em que o tamanho da partícula permanece inalterado após o término da reação devido à formação de uma camada de passivação (LEVENSPIEL, 1972; adaptação do autor).

b) O tamanho das partículas reduz ao longo da reação química, conforme ilustrado na Figura 14, devido à formação de cinzas que se desprendem da partícula, à geração de subprodutos solúveis, ou até mesmo ao grau de pureza do sólido utilizado na reação. 


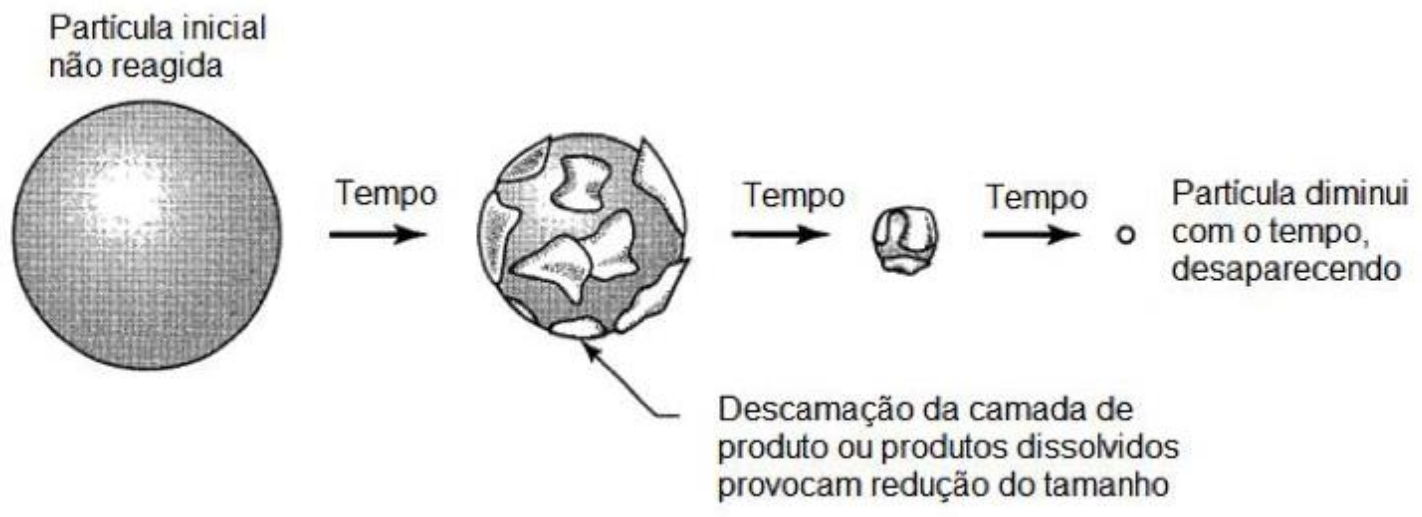

Figura 14 - Comportamento das partículas nas reações heterogêneas em que o tamanho das partículas reduz de tamanho ao longo da reação devido à inexistência de uma camada de passivação (LEVENSPIEL, 1972; adaptação do autor).

\subsubsection{Modelos cinéticos para a reação de lixiviação}

O sucesso na escolha do modelo cinético da reação de lixiviação depende da definição de um modelo matemático e da sua respectiva equação que representem a realidade da forma mais fiel possível (Ramunno, 2015).

Segundo OLIVEIRA (2012), os modelos mais comumente aplicados a reações sólido-líquido - como é o caso das reações de lixiviação - são:

- Modelo do Núcleo Não-Reagido (Shrinking Core Mode);

- Modelo da Partícula de Tamanho Decrescente (Shrinking Particle Model);

- Modelo de Grãos (Grain Model); e

- Modelo de Fragmentação em Grãos (Cracking Shrinking Model)

Segundo RAMUNNO (2015), o comportamento das reações de lixiviação de $\mathrm{PCl}$ segue tipicamente o Modelo do Núcleo Não-Reagido para Partículas Esféricas, dado que cerca de $70 \%$ em massa das $\mathrm{PCl}$ são compostos de materiais cerâmicos e poliméricos e que, portanto, não serão dissolvidos.

Uma vez definido o modelo, faz-se necessário identificar a etapa controladora da reação. 


\subsubsection{Etapa controladora da reação de lixiviação}

O Modelo do Núcleo Não-Reagido para Partículas Esféricas foi inicialmente desenvolvido por Yagi e Kunii entre 1955 e 1961, no qual definiram as cinco principais etapas sucessórias ao longo da reação química, conforme pode ser visto no esquema da Figura 15 (Levenspiel, 1972):

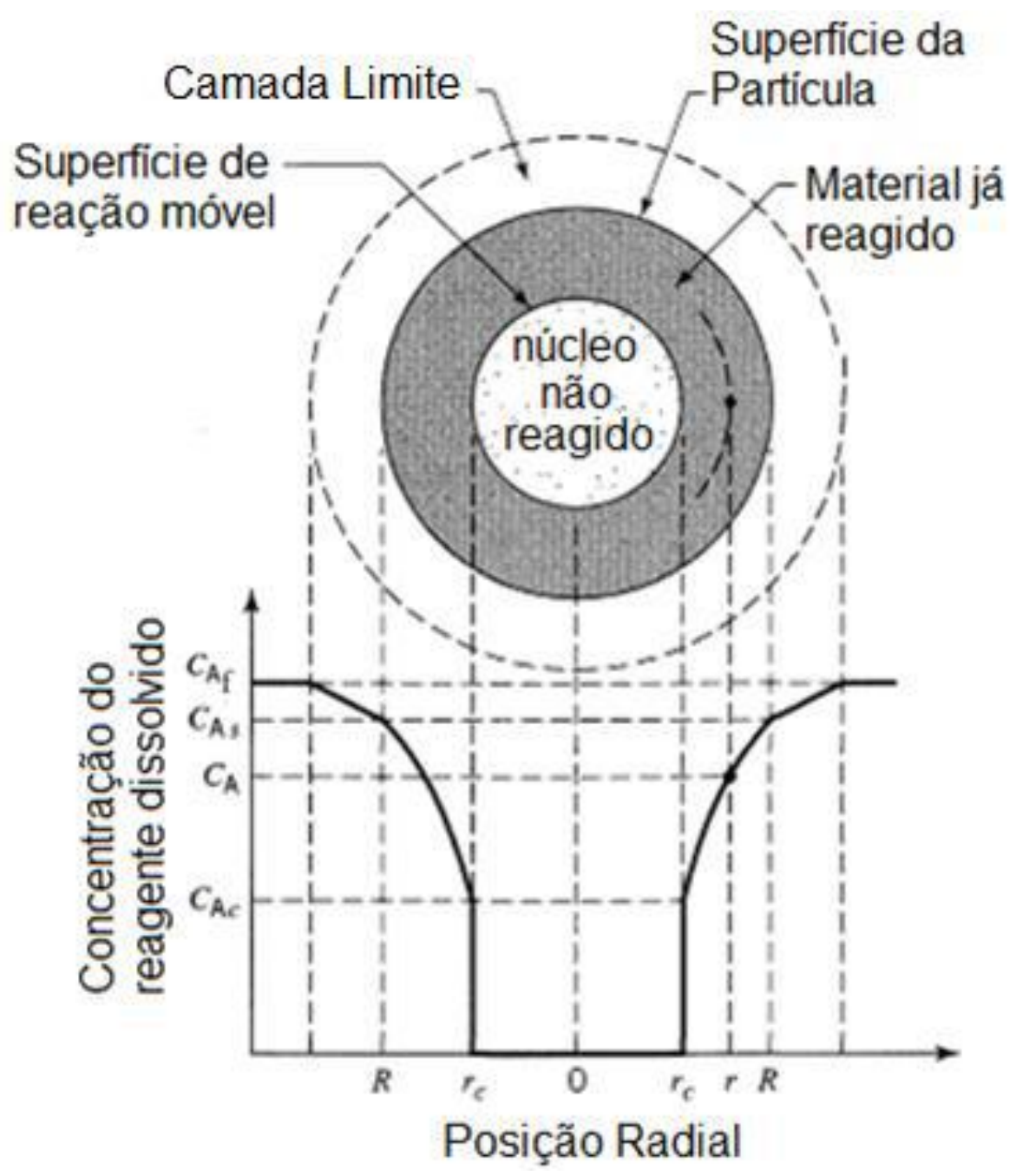

Figura 15 - Representação das concentrações de reagentes e produtos para a reação $\mathrm{A}(\mathrm{g})+\mathrm{bB}(\mathrm{s}) \rightarrow$ produtos sólidos, para partícula de tamanho constante (LEVENSPIEL, 1972; adaptação do autor).

- Etapa 1: difusão do reagente fluido "A" pelo filme que circunda a partícula até a superfície do sólido;

- Etapa 2: penetração e difusão do reagente fluido "A" através da camada de cinzas até a superfície do núcleo não-reagido; 
- Etapa 3: reação do reagente fluido "A" com o sólido na superfície deste sólido;

- Etapa 4: difusão dos produtos fluidos através da camada de cinzas de volta à superfície exterior do sólido;

- Etapa 5: difusão dos produtos fluidos através do filme que circunda a partícula, de volta ao meio fluido.

Considerando que algumas destas etapas podem não existir sob determinadas condições, no caso das reações de lixiviação de metais tem-se, em grande parte das vezes, as seguintes etapas que podem ser controladoras da reação (Levenspiel, 1972):

- Controle por difusão na camada limite, no qual o reagente " $A$ " difunde através da camada limite $e$ as concentrações deste reagente na superfície da partícula e na frente de reação são nulas;

- Controle por difusão na camada de cinzas, no qual o reagente "A" difunde através da camada de produto, sendo esta a etapa mais lenta do processo; ou

- Controle por reação química, no qual a velocidade das reações químicas são mais lentas que a taxa de difusão do reagente "A" pelas camadas limites.

A identificação da etapa controladora das reações químicas permite determinar as condições ótimas de trabalho e assim dimensionar os reatores químicos ao propósito do processo (Hill Jr. \& Root, 2014).

ABDEL-AAL (2000) realizou um estudo sobre os mecanismos controladores cinéticos da lixiviação de zinco com ácido sulfúrico à temperatura de $70^{\circ} \mathrm{C}$. $\mathrm{O}$ autor concluiu que a lixiviação do zinco, nas condições específicas do ensaio realizado, é controlada pela taxa de difusão ao longo de todo o tempo da reação, e que a taxa de reação aumenta com a temperatura. Calculou ainda a energia de ativação da reação no valor de $13,4 \mathrm{~kJ} / \mathrm{mol}$, que é consistente com os valores de energia de ativação típicos de reações controladas por difusão.

JHA et al. (2012) analisaram o mecanismo e a cinética da reação de lixiviação seletiva do chumbo de soldas presentes em PCl através da utilização de ácido nítrico, controlando e analisando os efeitos da temperatura, proporção sólido-líquido, tempo 
de reação e concentração do agente lixiviante. Conclui que a cinética da reação obedece a equação do mecanismo controlador por reação química, com energia de ativação de $26,94 \mathrm{~kJ} / \mathrm{mol}$.

KIM et al. (2011) realizaram um trabalho sobre a cinética da reação de lixiviação de cobre, zinco, chumbo e estanho de $\mathrm{PCl}$, obtendo a indicação de que a etapa controladora do processo de lixiviação do cobre era a difusão do agente lixiviante pela camada limite, e cuja energia de ativação foi calculada em $24,5 \mathrm{~kJ} / \mathrm{mol}$ à temperatura de $298 \mathrm{~K}$, nas condições específicas dos ensaios realizados.

RAMUNNO (2015) propôs uma metodologia de estudo da cinética da reação de lixiviação de metais de $\mathrm{PCl}$ objetivando a determinação da etapa controladora do processo, utilizando-se do Método do Tempo Reduzido como meio de obtenção da expressão matemática que representa a etapa controladora. 


\section{OBJETIVOS}

O objetivo deste trabalho é avaliar a lixiviação de ferro de placas de circuito impresso como alternativa ao processo de separação magnética, dentro de um contexto de recuperação de metais valiosos de resíduos de equipamentos eletroeletrônicos e considerando que a presença deste elemento influi negativamente na extração do cobre dos REEE. 


\section{MATERIAIS E MÉTODOS}

Para este estudo foi separada uma parcela de $2 \mathrm{~kg}$ do material previamente processado por CORREA (2015), cujo trabalho utilizou inicialmente $14 \mathrm{~kg}$ (ou cerca de 25 unidades, já considerando a etapa de desmantelamento manual) de placas de circuito impresso de microcomputadores obsoletos.

Este material foi doado pelo CEDIR-USP (Centro de Descartes e Reuso de Resíduos de Informática da Universidade de São Paulo), em convênio com o LAREX (Laboratório de Reciclagem, Tratamento de Resíduos e Extração).

A Figura 16 apresenta a imagem de uma unidade de placa-mãe típica utilizada neste trabalho, sem os componentes acessórios e periféricos.

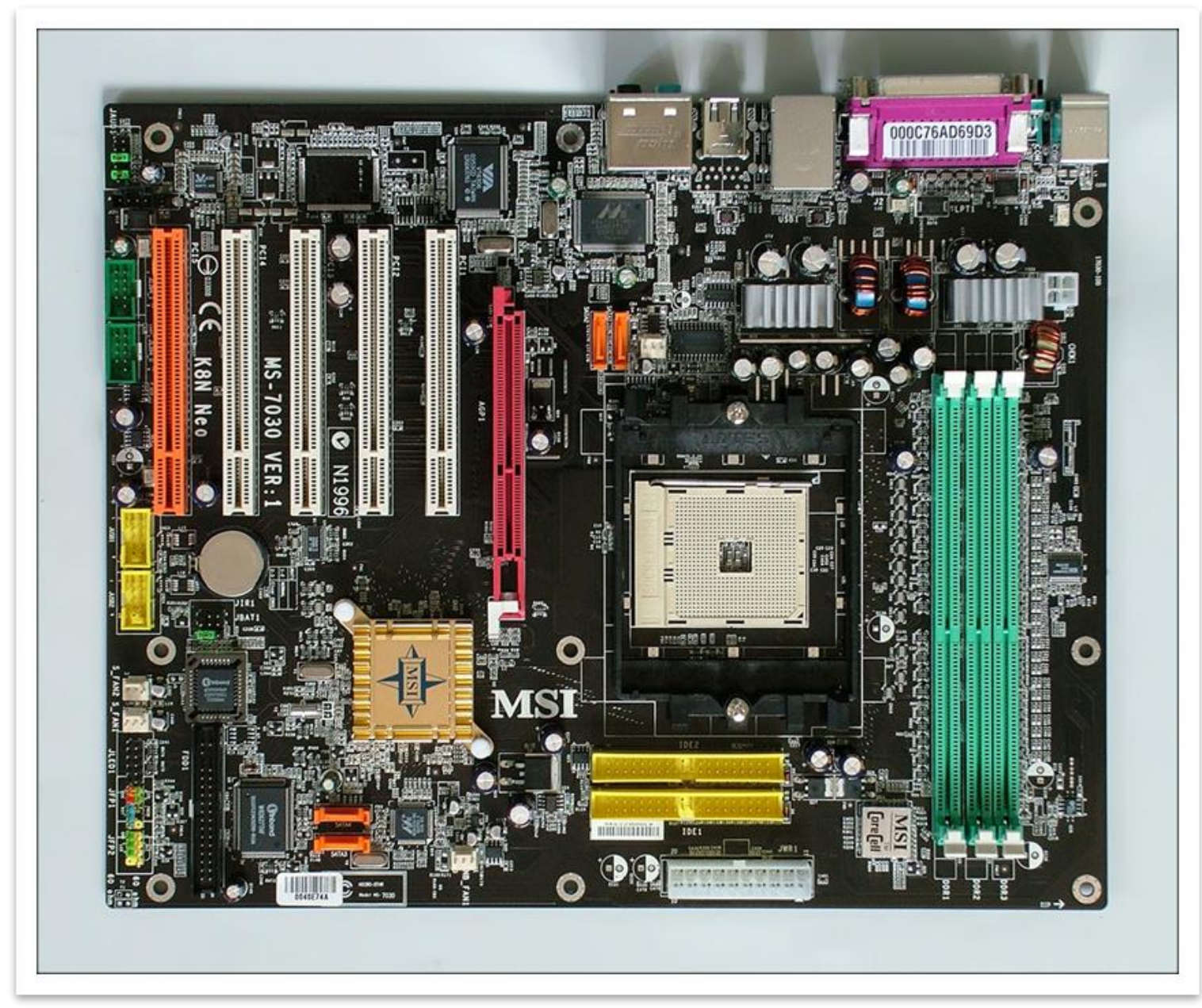

Figura 16 - Vista superior da placa-mãe de computador pessoal de mesa, sem os componentes acessórios à placa. 
As $\mathrm{PCl}$ utilizadas neste trabalho são provenientes de equipamentos de informática obsoletos, de fabricantes e tecnologias diversas. De acordo com CORREA (2015), estas placas foram escolhidas aleatoriamente no depósito do CEDIR e em número significativo com a finalidade de se obter representatividade estatística. Desta forma, procurou-se reduzir as influências das diferenças nas composições dos inúmeros modelos de placas, e consequentemente objetivando amostras mais homogêneas e resultados com os menores desvios padrão possíveis.

Estas $\mathrm{PCl}$ foram então submetidas a processamentos físico e hidrometalúrgico. Todas as etapas físicas - desde o desmantelamento até a última moagem - foram realizadas por CORREA (2015), o que possibilitou este trabalho manter o foco na etapa hidrometalúrgica.

O diagrama com as principais etapas é apresentado na Figura 17.

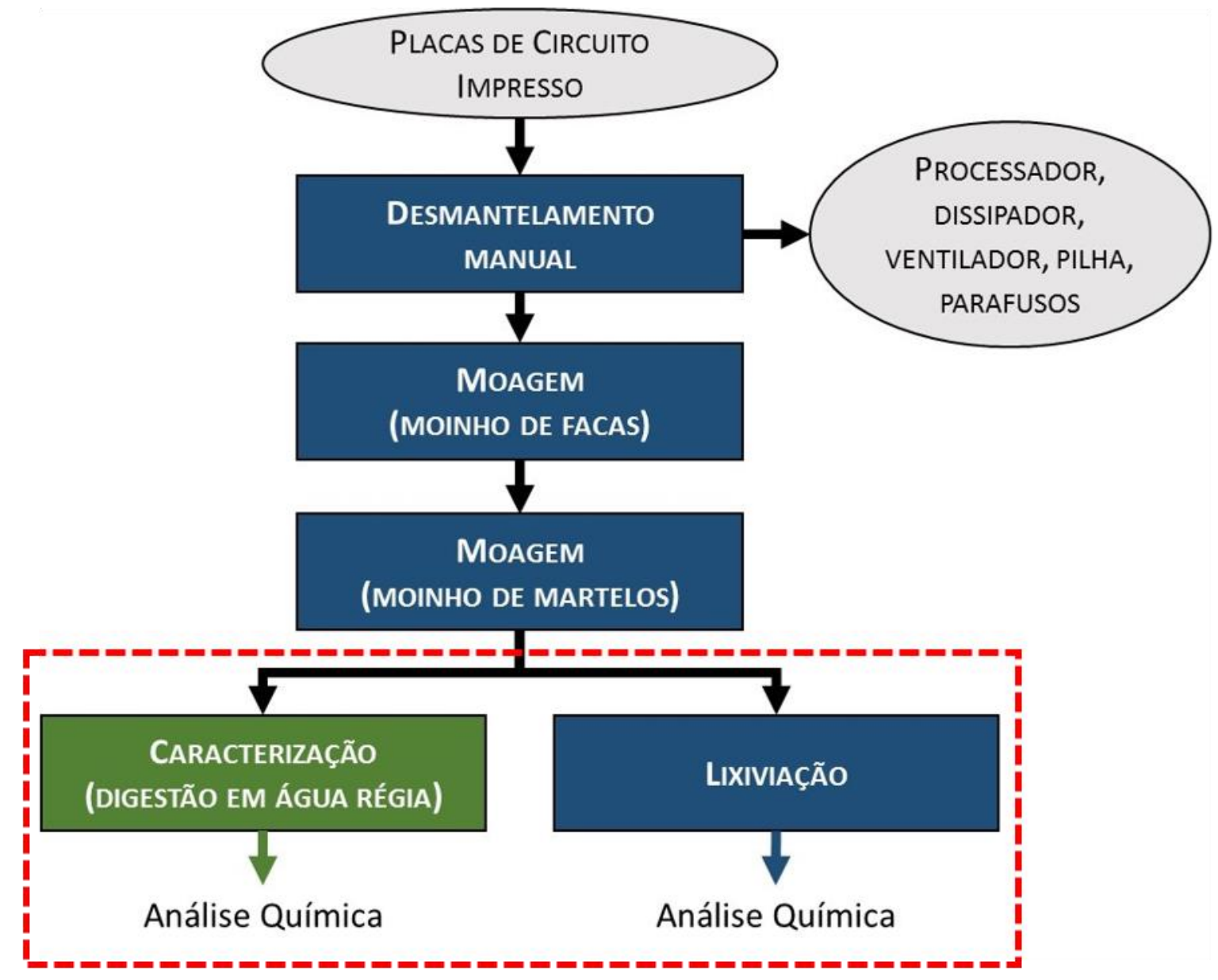

Figura 17 - Diagrama com as principais etapas do processo (apenas os processos em destaque foram realizados neste trabalho). 


\subsection{PROCESSAMENTO FÍSICO}

O processamento mecânico das $\mathrm{PCl}$ foi feito essencialmente através de Operações Unitárias de Tratamento de Minérios.

As operações utilizadas por CORREA (2015) no processamento destes materiais foram:
a) Desmantelamento manual;
b) Moagem; e
c) Quarteamento.

\subsubsection{Desmantelamento manual}

A primeira etapa do processo foi o desmantelamento manual, que tinha como finalidades remover e separar os elementos das placas-mãe que não eram permanentemente afixados às placas de circuito impresso. Além de prejudiciais ao processo subsequente de moagem, alguns destes componentes podem apresentar riscos à saúde humana - tais como pilhas e baterias - e portanto é desejável que estes sejam removidos e tratados separadamente CORREA (2015).

\subsubsection{Cominuição}

Finalizada a etapa de desmantelamento das $\mathrm{PCI}$ com a separação manual dos componentes removíveis das placas-mãe, estas foram submetidas por CORREA (2015) ao processo de cominuição através de moagem.

A moagem teve como principal objetivo cominuir as placas-mãe em busca de um aumento da superfície específica das $\mathrm{PCl}$, com o intuito de aumentar a cinética do posterior processo de recuperação dos metais.

E etapa de cominuição escolhida por CORREA (2015) envolveu dois processos consecutivos: moagem em moinho de facas e moagem em moinho de martelos.

Utilizou-se o moinho de facas modelo FA-2305 da fabricante Rone, com grelha de $9 \mathrm{~mm}$, conforme mostra a Figura 18. 


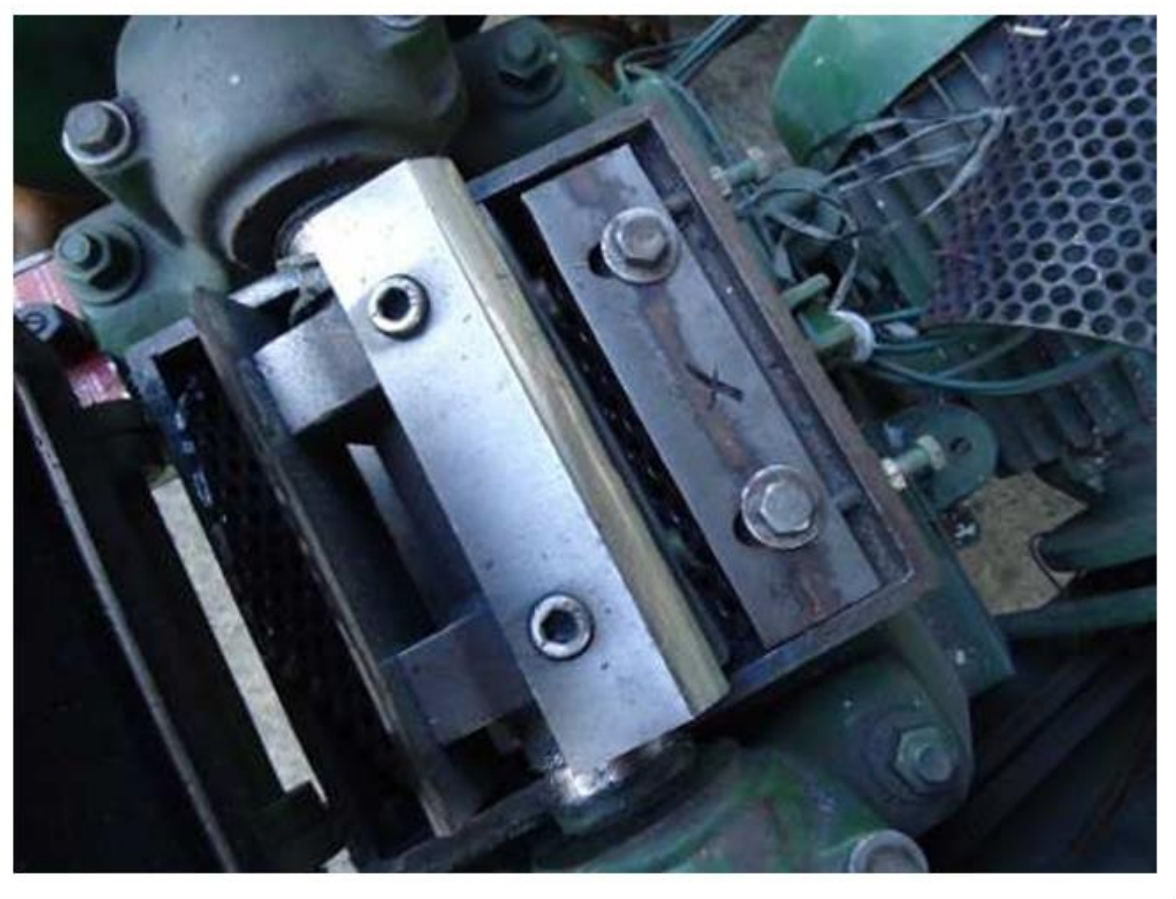

Figura 18 - Detalhe do interior do moinho de facas mostrando as lâminas e a grelha utilizadas neste trabalho.

Foram moídos ao todo cerca de $14 \mathrm{~kg}$ de $\mathrm{PCl}$, já descontados os componentes retirados na etapa de desmantelamento manual. Na sequência, as amostras foram processadas em um moinho de martelos da marca Astecma, modelo MDM 18/18, com grelhas de $6 \mathrm{~mm}, 4 \mathrm{~mm}$ e $2 \mathrm{~mm}$, na sequência (CORREA, 2015).

O produto das moagens foi coletado e então quarteado.

\subsubsection{Quarteamento}

O material resultante do processo de moagem foi então quarteado em amostras de $20 \pm 5 \mathrm{~g}$ com o auxílio de um quarteador tipo Jones, modelo MA065 com canais de $1 / 2$ " de largura, da fabricante Marconi, conforme equipamento apresentado na Figura 19. 


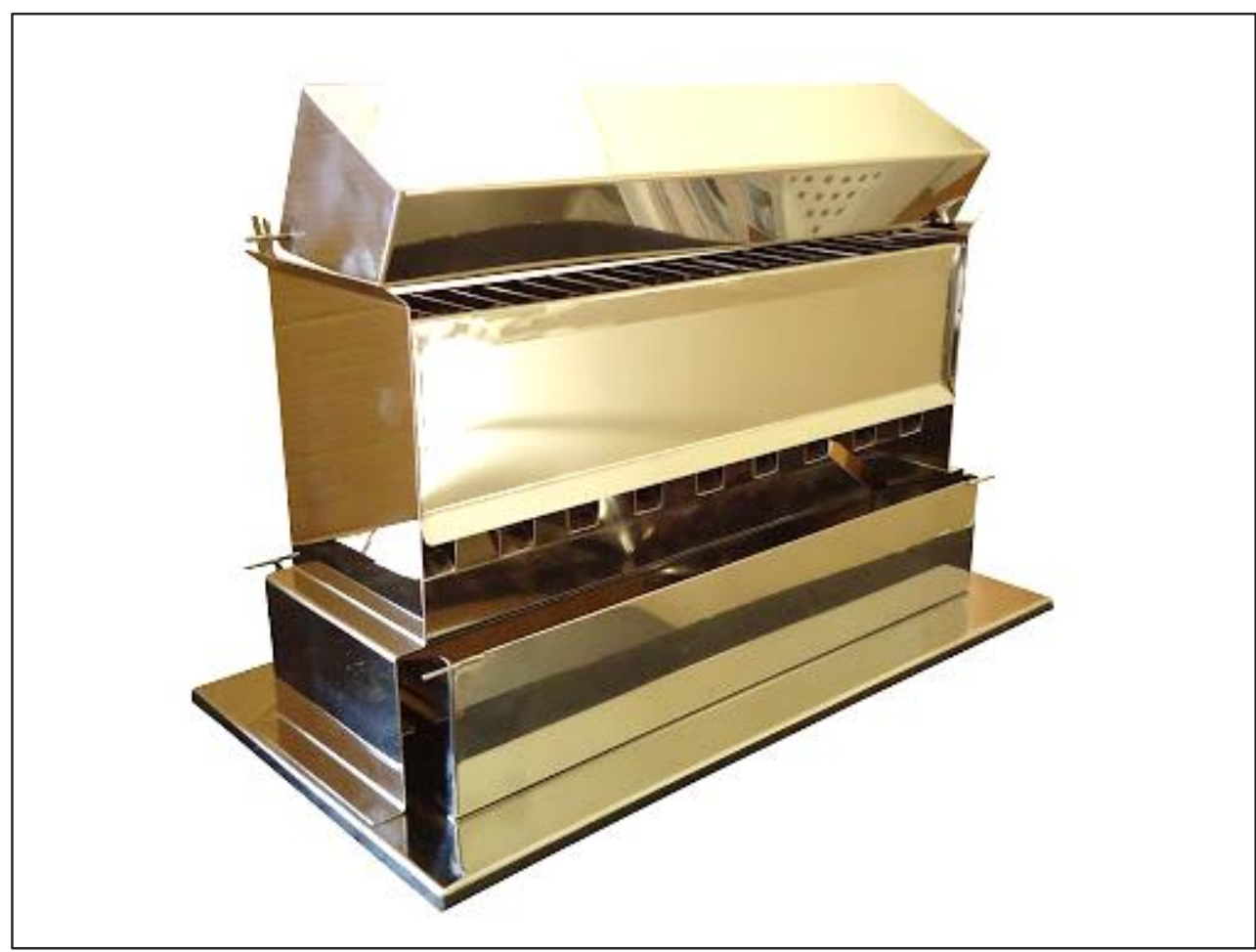

Figura 19 - Imagem de quarteador tipo Jones utilizado no preparo das amostras.

As $\mathrm{PCl}$ foram individualmente pesadas e, na sequência, submetidas ao processamento hidrometalúrgico.

\subsection{CARACTERIZAÇÃO}

Foi realizado ensaio de digestão em água régia (ácido clorídrico e ácido nítrico nas relações volumétricas de 3:1) de uma amostra obtida do processo de quarteamento de aproximadamente $20 \mathrm{~g}$ para se determinar a quantidade dos elementos presentes em uma amostra de $\mathrm{PCl}$ cominuída.

Neste procedimento foi utilizada a relação sólido:líquido 1:20, ou seja, para cada $1 \mathrm{~g}$ de amostra foram adicionados $20 \mathrm{~mL}$ de água régia. A massa de amostra utilizada foi de $20,0853 \mathrm{~g}$.

O ensaio foi realizado em um béquer de $1000 \mathrm{~mL}$ à temperatura ambiente pelo período de $24 \mathrm{~h}$, dentro de uma capela.

Após seu término, todo o conteúdo foi filtrado em papel de filtro quantitativo de filtragem rápida. O filtro contendo o resíduo não-lixiviado foi então lavado e posto em estufa a $60^{\circ} \mathrm{C}$ pelo período de 48 horas. Do licor de água régia contendo os metais 
lixiviados foi retirada alíquota para análise posterior da porcentagem de extração de metais.

\subsection{PROCESSAMENTO HIDROMETALÚRGICO}

O processamento hidrometalúrgico foi realizado através de ensaios de lixiviação ácida, com a exposição das amostras a agentes lixiviantes em diferentes temperaturas e diferentes concentrações, sob tempos de exposição variáveis e controlados.

Os ensaios de lixiviação ácida foram conduzidos com ácido sulfúrico, tendo como variáveis do processo a concentração de ácido, a temperatura de trabalho e o tempo de lixiviação. Desta forma, foi possível avaliar a extração de ferro da amostra e sua influência nos processos de lixiviação de outros metais.

Para efeitos de nomenclatura das amostras, adotou-se um padrão no qual a primeira letra indica que o ensaio foi feito em meio ácido ("H"), os dois algarismos seguintes indicam a concentração do ácido ("xM" para $x \mathrm{~mol} / \mathrm{L}$ ), e os números que antecedem a letra "C" indicam a temperatura do ensaio em graus Celsius.

Seguindo este padrão de nomenclatura, uma amostra de ensaio com ácido sulfúrico à concentração de $1 \mathrm{~mol} / \mathrm{L}$, realizado a $75^{\circ} \mathrm{C}$, por exemplo, receberá o código H1M75C.

Neste trabalho, foram feitos ensaios de lixiviação utilizando ácido sulfúrico nas concentrações de $1 \mathrm{~mol} / \mathrm{L}$ e $2 \mathrm{~mol} / \mathrm{L}$, cada um às temperaturas de $75^{\circ} \mathrm{C}$, $85^{\circ} \mathrm{C}$ e $95^{\circ} \mathrm{C}$.

Utilizou-se a proporção sólido-líquido de $1 \mathrm{~g}: 10 \mathrm{~mL}$. Ou seja, para cada $1 \mathrm{~g}$ de amostra foram adicionados $10 \mathrm{~mL}$ de ácido sulfúrico.

As amostras foram pesadas individualmente em balança analítica e então reservadas. As massas das amostras e os volumes de ácido a que elas foram expostas podem ser vistas na Tabela 11. 
Tabela 11 - Massa das amostras utilizadas nas lixiviações e respectivos volumes de ácido.

\begin{tabular}{ccc}
\hline $\begin{array}{c}\text { Código da } \\
\text { amostra }\end{array}$ & Massa (g) & $\begin{array}{c}\text { Volume de } \\
\mathbf{H}_{2} \mathbf{S O}_{4}(\mathbf{m L})\end{array}$ \\
\hline H1M75C & 20,6383 & 210 \\
H1M85C & 23,5009 & 240 \\
H1M95C & 22,0065 & 220 \\
H2M75C & 21,8873 & 220 \\
H2M85C & 21,2971 & 220 \\
H2M95C & 22,2403 & 230 \\
\hline
\end{tabular}

Após o cálculo e a medição de volume de ácido a ser utilizado nas reações, para cada amostra de PCI utilizou-se um balão de fundo chato e cinco bocas, e neles foram despejados os ácidos.

Os balões foram colocados sobre chapas de aquecimento e agitação magnética, e montados de acordo com o esquema apresentado na Figura 20.

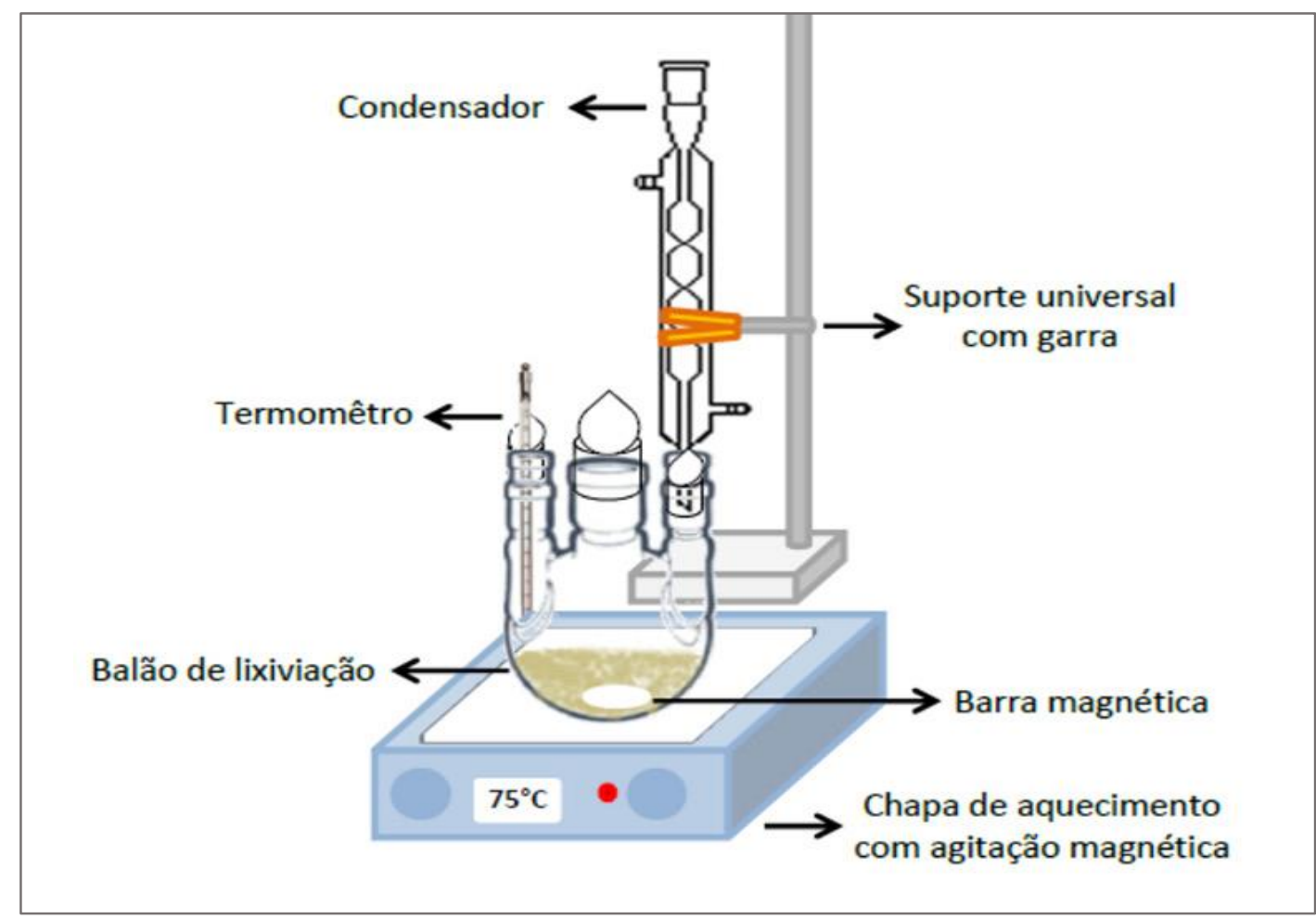

Figura 20 - Diagrama esquemático do sistema usado no processo de lixiviação ácida (SILVAS, 2014; CALDAS et al., 2015).

Procurando evitar ao máximo a perda de ácido por evaporação, foram conectados dois condensadores a cada balão, resfriados com água destilada à temperatura constante de $7^{\circ} \mathrm{C}$ através de um refrigerador em circuito fechado. Foi 
ainda adicionado um termômetro em cada balão, para monitorar a temperatura ao longo de todo o ensaio, como mostra a Figura 21.

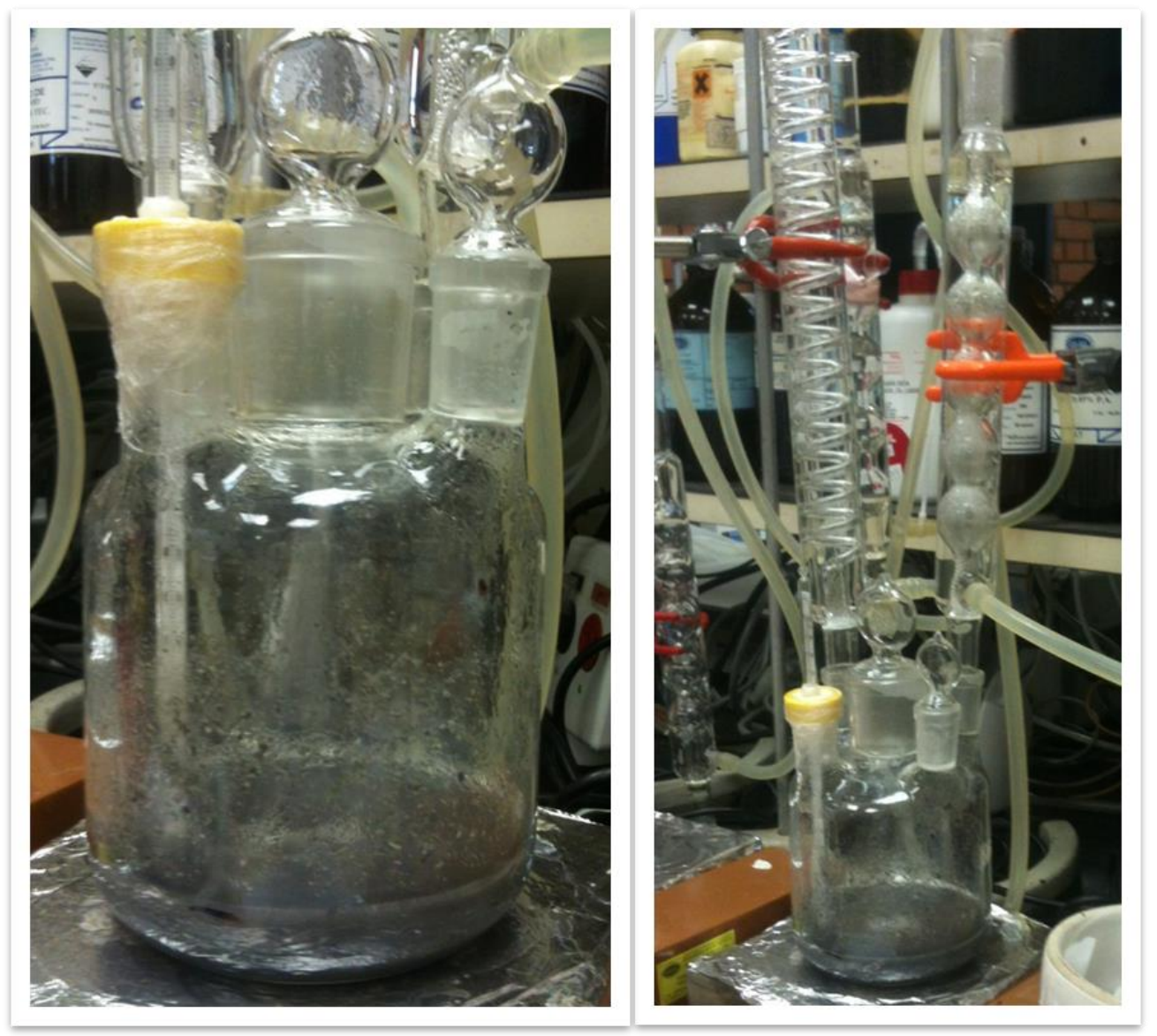

Figura 21 - Esquema do balão de fundo chato e cinco bocas utilizado no processo de lixiviação ácida. No detalhe à esquerda, o termômetro mergulhado na solução.

Para manter os ensaios os mais homogêneos possível, foram utilizadas barras magnéticas revestidas de teflon a aproximadamente $200 \mathrm{rpm}$, rotação baixa o suficiente para não espirrar amostra nas paredes do balão, mas suficientemente alta para manter o seu conteúdo homogeneizado.

$\mathrm{Na}$ sequência, as soluções de ácido sulfúrico $1 \mathrm{~mol} / \mathrm{L}$ e $2 \mathrm{~mol} / \mathrm{L}$ foram aquecidas até as temperaturas desejadas, e após estas atingirem estabilidade foram despejadas as amostras de placas-mãe cominuídas no interior de cada balão.

A partir do início do ensaio, foram retiradas alíquotas de 5,0mL nos seguintes tempos: $1 \mathrm{~h}, 2 \mathrm{~h}, 4 \mathrm{~h}, 8 \mathrm{~h}$ e $24 \mathrm{~h}$. Cada alíquota foi recolhida com o cuidado para se obter a menor quantidade de sólidos possível; ainda assim, as alíquotas foram filtradas com 
papel de filtro quantitativo de filtragem rápida. Cada alíquota foi reservada em tubos separados e devidamente identificados.

Após as últimas alíquotas, os filtros foram lavados e postos em estufa a $60^{\circ} \mathrm{C}$ durante $24 \mathrm{~h}$ para secagem e posteriores pesagens. Os volumes finais de ácido foram aferidos e anotados.

\subsection{ANÁLISES QUÍMICAS}

Amostras dos ensaios H1M75C, H1M85C, H1M95C, H2M75C, H2M85C e H2M95C foram enviadas para análise química por espectrometria de emissão óptica com plasma acoplado indutivamente (ICP-OES), nas alíquotas de $1 \mathrm{~h}, 2 \mathrm{~h}, 4 \mathrm{~h}$, $8 \mathrm{~h}$ e $24 \mathrm{~h}$ de cada ensaio, cada uma delas diluída em ácido nítrico $1 \%$ em volume nas proporções de 1:10, 1:100, 1:1000 e 1:10000.

O licor do ensaio de caracterização com água régia também foi submetido à análise química por ICP-OES para identificação dos elementos presentes na amostra de $\mathrm{PCl}$ e respectivas quantificações, cujos resultados foram utilizados como valores de referência para efeitos de cálculos de percentuais de extração. Estas amostras foram diluídas em água destilada e deionizada nas proporções de 1:10, 1:100, 1:500 e $1: 1000$.

O equipamento utilizado para a realização de tais análises foi um 710 series ICP-OES da fabricante Agilent Technologies.

Os elementos analisados neste processo foram alumínio, cobre, ferro, níquel e zinco.

As curvas de calibração foram definidas utilizando 10 padrões de referência multi-elementares, com as amostras previamente diluídas para que o equipamento pudesse efetuar as leituras dentro das respectivas curvas de calibração.

\subsection{ANÁLISE DA CINÉTICA DA REAÇÃO DE LIXIVIAÇÃO}

Com a finalidade de identificar o mecanismo controlador da cinética da reação de lixiviação ácida dos metais presentes - em especial o ferro -, foi aplicado o Método do Tempo Reduzido em todos os ensaios de lixiviação realizados. 


\subsubsection{Determinação da etapa controladora da reação de lixiviação do ferro}

O método de determinação do mecanismo controlador em estudos cinéticos de reações heterogêneas envolve a tentativa de linearizar os resultados experimentais através de equações matemáticas, cujo formato geral é dado pela Equação 12.

$$
t / \tau=k . t=f\left(X_{B}\right)
$$

Equação 12

onde $t$ é o tempo; $\tau$ é o tempo total da reação química; $k$ é a constante aparente de velocidade da reação; e $X_{B}$ é a fração reagida da reação.

Cada etapa do modelo cinético possui uma equação que melhor a representa. Dentre as inúmeras reações possíveis, para o caso específico de lixiviação ácida de REEE há basicamente quatro possibilidades aplicáveis (Ramunno, 2015).

\subsubsection{Equações lineares dos mecanismos controladores das reações químicas de lixiviação}

As equações a seguir representam os mecanismos controladores mais frequentemente encontrados nos processos de lixiviação ácida de REEE.

A Equação 13 representa o mecanismo controlador por reações químicas, no qual a cinética das reações que ocorrem na lixiviação são mais lentas - e portanto restritivas - que os mecanismos de difusão pela camada limite e pela camada de cinzas (Levenspiel, 1972).

$$
t / \tau=k \cdot t=1-\left(1-X_{B}\right)^{\frac{1}{3}}
$$

Equação 13

A Equação 14 representa as reações controladas por difusão do reagente através da camada de cinzas (Levenspiel, 1972).

$$
t / \tau=k \cdot t=1-3\left(1-X_{B}\right)^{\frac{2}{3}}+2\left(1-X_{B}\right) \quad \text { Equação } 14
$$


A Equação 15 representa as reações controladas por difusão do reagente através da camada limite que envolve as partículas (Levenspiel, 1972).

$$
t / \tau=k \cdot t=1-\left(1-X_{B}\right)^{\frac{2}{3}}
$$

Equação 15

Por fim, a Equação 16 representa as reações controladas por reações químicas de $1^{\mathrm{a}}$ ordem (Mourão, 1988).

$$
t / \tau=k \cdot t=-\ln \left(1-X_{B}\right)
$$

\subsubsection{Método do Tempo Reduzido}

O Método do Tempo Reduzido (ÇAMCI, AYDIN e ARSLAN, 2002; MOOKHERJEE e RAY, 1996; MOURÃO, 1988) é uma ferramenta que permite simplificar os cálculos feitos em busca da determinação da equação que corresponde ao mecanismo controlador da reação química.

Neste método, é preciso selecionar uma equação de primeiro grau do tipo $f\left(X_{B}\right)=k . t$ verificando se a expressão é válida para qualquer instante de tempo $t$ através dos dados experimentais.

Na sequência, fixa-se um tempo arbitrário para que se possa substituir uma das variáveis da expressão geral. RAMUNNO (2015) estipula $X_{B}$ como o tempo necessário para que a reação atinja $50 \%$ de extração, ou seja, $X_{B}=0,5$; obtém-se, desta forma, a Equação 17.

$$
f\left(X_{B}=0,5\right)=f(0,5)=k \cdot t_{0,5} \quad \text { Equação } 17
$$

Dividindo a expressão geral pela expressão para $t_{0,5}$, obtém-se a Equação 18 que é adimensional e independe da constante de velocidade.

$$
\frac{f\left(X_{B}\right)}{f(0,5)}=\frac{t}{t_{0,5}}
$$


Desta forma, para uma dada função $f$ é possível calcular $f\left(X_{B}\right)$ e dividi-lo pelo valor de $f(0,5)$, obtendo-se $o$ valor de $t / t_{0,5}$, o chamado Parâmetro de Tempo Reduzido para cada $X_{B}$.

Com os valores obtidos nesta etapa, constroem-se as curvas de $X_{B}$ em função de $t / t_{0,5}$. Os pontos obtidos com valores experimentais deverão coincidir com a curva da função que representa o mecanismo controlador da reação química em questão.

\subsubsection{Cálculo da energia de ativação}

Determinado o mecanismo controlador da reação química e identificada a expressão matemática que a representa, pode-se calcular as constantes aparentes de velocidade para uma determinada temperatura através do cálculo do coeficiente angular da reta que relaciona $f\left(X_{B}\right)$ e o tempo.

Uma vez obtidos os valores destas constantes, pode-se determinar a energia de ativação aparente dos processos através da Equação de Arrhenius, representada pela Equação 19 (Levenspiel, 1972).

$$
k=A \cdot \exp \left(\frac{-E_{a}}{R T}\right)
$$

onde A é o fator pré-exponencial, $E_{a}$ é a energia de ativação, R é a constante universal dos gases, e T é a temperatura absoluta em Kelvin.

O valor da energia de ativação encontrado permitirá validar o mecanismo de controle cinético da reação indicado, dado que processos controlados por difusão (pela camada limite ou pela camada de cinzas) apresentam valores de energia de ativação entre 4 e $12 \mathrm{~kJ} / \mathrm{mol}$, enquanto processos controlados por reações químicas apresentam valores de energia de ativação acima de 40kJ/mol (Abdel-Aal, 2000). 


\section{RESULTADOS E DISCUSSÃO}

\subsection{PROCESSAMENTO FÍSICO}

\subsubsection{Desmantelamento manual}

A etapa de desmantelamento manual foi fundamental para garantir que somente os componentes permanentemente afixados às placas fossem processados, garantindo assim a homogeneidade das amostras com o mínimo de interferência de materiais que pudessem prejudicar a etapa de moagem, ou até mesmo de materiais tóxicos ou perigosos CORREA (2015).

Conectores, cabos, baterias, ventiladores, dissipadores de calor e processador foram retirados manualmente e separados por CORREA (2015). Alguns desses elementos são mostrados isoladamente na Figura 22. 

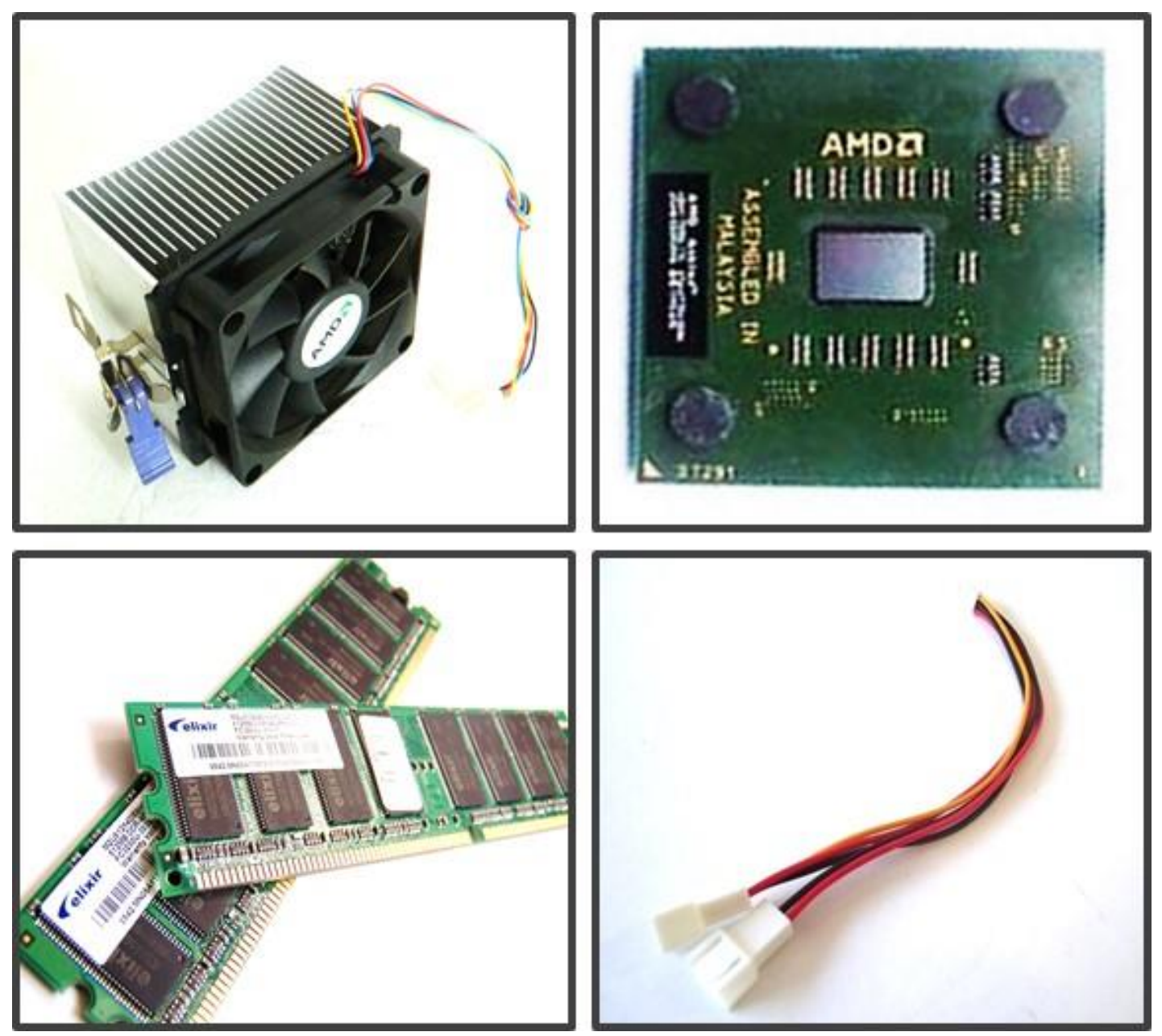

Figura 22 - Componentes que puderam ser removidos manualmente das placas-mãe sem o uso de ferramentas específicas, tais como dissipadores de calor, ventiladores, processadores, placas de memória, fios e cabos elétricos.

Uma vez que estes componentes são originalmente desenhados pelos seus fabricantes para serem encaixados e desacoplados com facilidade, nenhum tipo de ferramenta específica foi necessário nesta etapa.

A quantidade de componentes retirados nesta etapa corresponde a cerca de 9,7\% da massa total das placas CORREA (2014).

Com isto, somente os componentes fundamentais e afixados às $\mathrm{PCl}$ foram submetidos ao processo seguinte de cominuição, garantindo maior homogeneidade e controle das amostras.

\subsubsection{Cominuição}

A primeira etapa da cominuição foi realizada por CORREA (2015) em um moinho de facas com grelha de $9 \mathrm{~mm}$. Apesar da verificação visual da dispersão de 
partículas finas para a atmosfera durante o processo, não foi observado material retido na grelha. Ao final desta etapa registrou-se o valor de $0,5 \%$ de perdas.

A etapa seguinte foi realizada em um moinho de martelos, em etapas consecutivas utilizando grelhas de $6 \mathrm{~mm}, 4 \mathrm{~mm}$ e $2 \mathrm{~mm}$. Não foi observado material retido na grelha em nenhuma das etapas, razão pela qual considerou-se que todo o material processado foi considerado passante CORREA (2015).

\subsection{CARACTERIZAÇÃO}

Neste ensaio, os metais foram lixiviados pela água régia, enquanto os materiais poliméricos e cerâmicos não-reagiram e permaneceram como resíduos do processo.

A digestão em água régia resultou em um licor com coloração fortemente esverdeada, como pode ser visto na Figura 23.

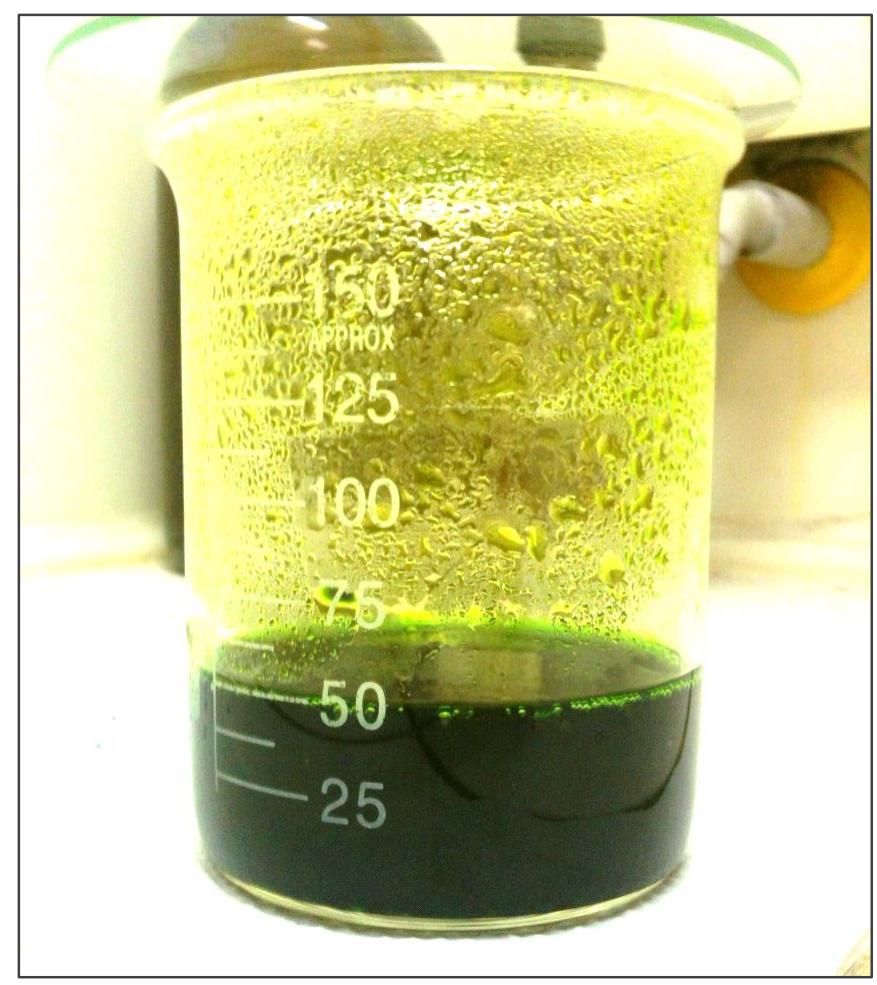

Figura 23 - Licor com coloração esverdeada produto da digestão em água régia das placas-mãe.

Ao final do processo de digestão em água régia, constatou-se que $36 \%$ da massa das amostras foram lixiviadas, o que representa a fração de materiais metálicos 
nas placas-mãe. Tal resultado é coerente com diversos trabalhos publicados na literatura, como por exemplo os resultados obtidos por SILVA et al. (2014) com 35,5\%; CORREA (2015) com 35,3\%; CALDAS et al. (2014) com 43,7\%; PARK e FRAY (2009) com 33,1\%; CUI e ZHANG (2008) com 34,5\%.

Os resultados do ensaio de digestão em água régia foram então submetidos à análise química por ICP-OES, gerando os valores apresentados na Figura 24 CORREA (2015).

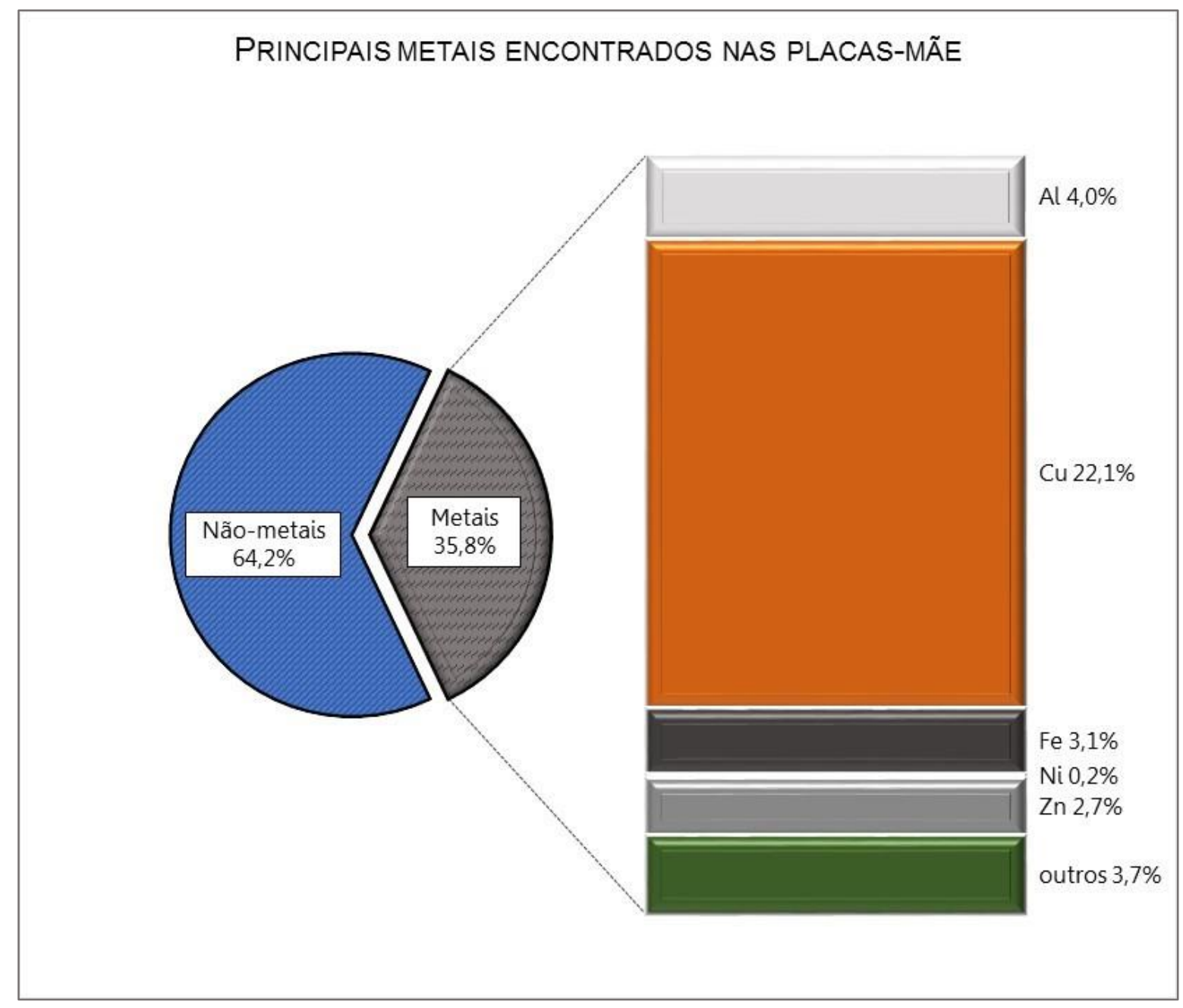

Figura 24 - Resultados da análise química por ICP-OES do licor resultante da digestão em água régia para caracterização das amostras de placas-mãe, mostrando os percentuais dos principais elementos metálicos encontrados na amostra (CORREA, 2015).

Os resultados da análise química do licor resultante da digestão em água régia serviram como base de cálculo da eficácia dos ensaios de lixiviação com ácido sulfúrico. Para tanto, considerou-se que todos os metais presentes no ensaio de 
digestão em água régia foram lixiviados, desta forma representando a totalidade da quantidade de metais presentes nas $\mathrm{PCl}$ analisadas.

Como nota, é importante ressaltar que os resultados obtidos na análise química realizada com esta amostra apresentaram incertezas quanto à sua representatividade perante o material utilizado nos ensaios de lixiviação, dado que estas análises foram feitas cerca de um mês após a conclusão do ensaio de digestão em água régia devido a dificuldades de natureza operacional. Com isto, a amostra pode ter sofrido degradação, comprometendo os resultados deste trabalho. Desta forma, optou-se por utilizar como referência os resultados do trabalho de CORREA (2015), uma vez que a matéria prima, a metodologia e os equipamentos utilizados foram exatamente os mesmos em ambos os trabalhos.

Assim, segundo CORREA (2015), a fração mássica de metal mais representativa nas placas-mãe é a do cobre, com $22,1 \%$ da massa total da amostra, seguido pela do alumínio $(4,0 \%)$, do ferro $(3,1 \%)$, do zinco $(2,7 \%)$ e do níquel $(0,2 \%)$, em massa. Outros elementos, tais como chumbo, estanho, ouro e prata, representam cerca de $3,7 \%$ da massa total. Com isto, conclui-se que a fração de metais presentes nas amostras representa $35,8 \%$ em massa das placas-mãe analisadas, e que os $64,2 \%$ restantes são compostos por materiais cerâmicos e poliméricos.

\subsection{ENSAIOS DE LIXIVIAÇÃO}

Os resultados das análises químicas por ICP-OES dos ensaios de lixiviação H1M75C, H1M85C, H1M95C, H2M75C, H2M85C e H2M95C apontaram que houve extração total de alguns determinados metais, de acordo com as condições utilizadas em cada ensaio. Ressalta-se que os valores de extração foram comparados ao total de cada respectivo metal presente na amostra, de acordo com os resultados obtidos no ensaio de caracterização das placas-mãe.

Os valores percentuais de extração dos metais alumínio, cobre, ferro, níquel e zinco nos ensaios utilizando ácido sulfúrico na concentração de $1 \mathrm{~mol} / \mathrm{L}$ são apresentados na Tabela 12, de acordo com os tempos de ensaio indicados. 
Tabela 12 - Resultados dos ensaios de extração de metais em ácido sulfúrico $1 \mathrm{~mol} / \mathrm{L}$ em 24 horas a diferentes temperaturas, em porcentagem em massa.

\begin{tabular}{|c|c|c|c|c|c|c|}
\hline$\#$ & $t(h)$ & Al (\%) & $\mathrm{Cu}(\%)$ & $\mathrm{Fe}(\%)$ & $\mathrm{Ni}(\%)$ & $\mathrm{Zn}(\%)$ \\
\hline \multirow{6}{*}{ 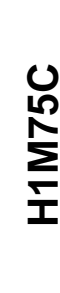 } & $\mathrm{Oh}$ & 0,0 & 0,0 & 0,0 & 0,0 & 0,0 \\
\hline & $1 \mathrm{~h}$ & 0,0 & 0,0 & 0,0 & 51,1 & 4,3 \\
\hline & $2 \mathrm{~h}$ & 6,2 & 0,0 & 23,4 & 66,3 & 4,8 \\
\hline & $4 \mathrm{~h}$ & 21,0 & 0,0 & 69,0 & 100,0 & 5,4 \\
\hline & $8 \mathrm{~h}$ & 21,0 & 0,0 & 78,6 & 100,0 & 6,5 \\
\hline & $24 \mathrm{~h}$ & 43,0 & 0,0 & 100,0 & 100,0 & 8,1 \\
\hline \multirow{6}{*}{$\begin{array}{l}\text { U } \\
\sum^{\infty} \\
\text { I }\end{array}$} & $\mathrm{Oh}$ & 0,0 & 0,0 & 0,0 & 0,0 & 0,0 \\
\hline & $1 \mathrm{~h}$ & 0,0 & 0,0 & 28,0 & 70,6 & 3,6 \\
\hline & $2 \mathrm{~h}$ & 8,4 & 0,0 & 39,4 & 76,3 & 4,0 \\
\hline & $4 \mathrm{~h}$ & 15,7 & 0,0 & 60,5 & 86,0 & 4,7 \\
\hline & $8 \mathrm{~h}$ & 22,7 & 0,0 & 87,5 & 95,6 & 5,4 \\
\hline & $24 \mathrm{~h}$ & 73,2 & 0,0 & 100,0 & 100,0 & 7,1 \\
\hline \multirow{6}{*}{ 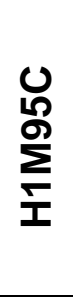 } & $\mathrm{Oh}$ & 0,0 & 0,0 & 0,0 & 0,0 & 0,0 \\
\hline & $1 \mathrm{~h}$ & 67,4 & 0,0 & 27,2 & 59,8 & 9,0 \\
\hline & $2 \mathrm{~h}$ & 100,0 & 0,0 & 86,2 & 79,9 & 9,3 \\
\hline & $4 \mathrm{~h}$ & 100,0 & 0,0 & 100,0 & 94,5 & 9,7 \\
\hline & $8 \mathrm{~h}$ & 100,0 & 0,0 & 100,0 & 100,0 & 10,4 \\
\hline & $24 \mathrm{~h}$ & 100,0 & 0,6 & 100,0 & 100,0 & 12,5 \\
\hline
\end{tabular}

Sob exposição ao ácido sulfúrico na concentração de $1 \mathrm{~mol} / \mathrm{L}$, observou-se um aumento crescente na dissolução dos metais alumínio, ferro, níquel e zinco: quanto maior a temperatura e quanto maior o tempo de exposição aos agentes lixiviantes, maior é a eficiência na extração destes metais.

$\mathrm{Na}$ Figura 25, na Figura 26 e na Figura 27 os elementos analisados são mostrados em curvas de percentuais de extração dos metais pelo tempo em horas, separados por ensaio com ácido sulfúrico em concentração de $1 \mathrm{~mol} / \mathrm{L}$ às temperaturas de $75^{\circ} \mathrm{C}, 85^{\circ} \mathrm{C}$ e $95^{\circ} \mathrm{C}$, respectivamente. 


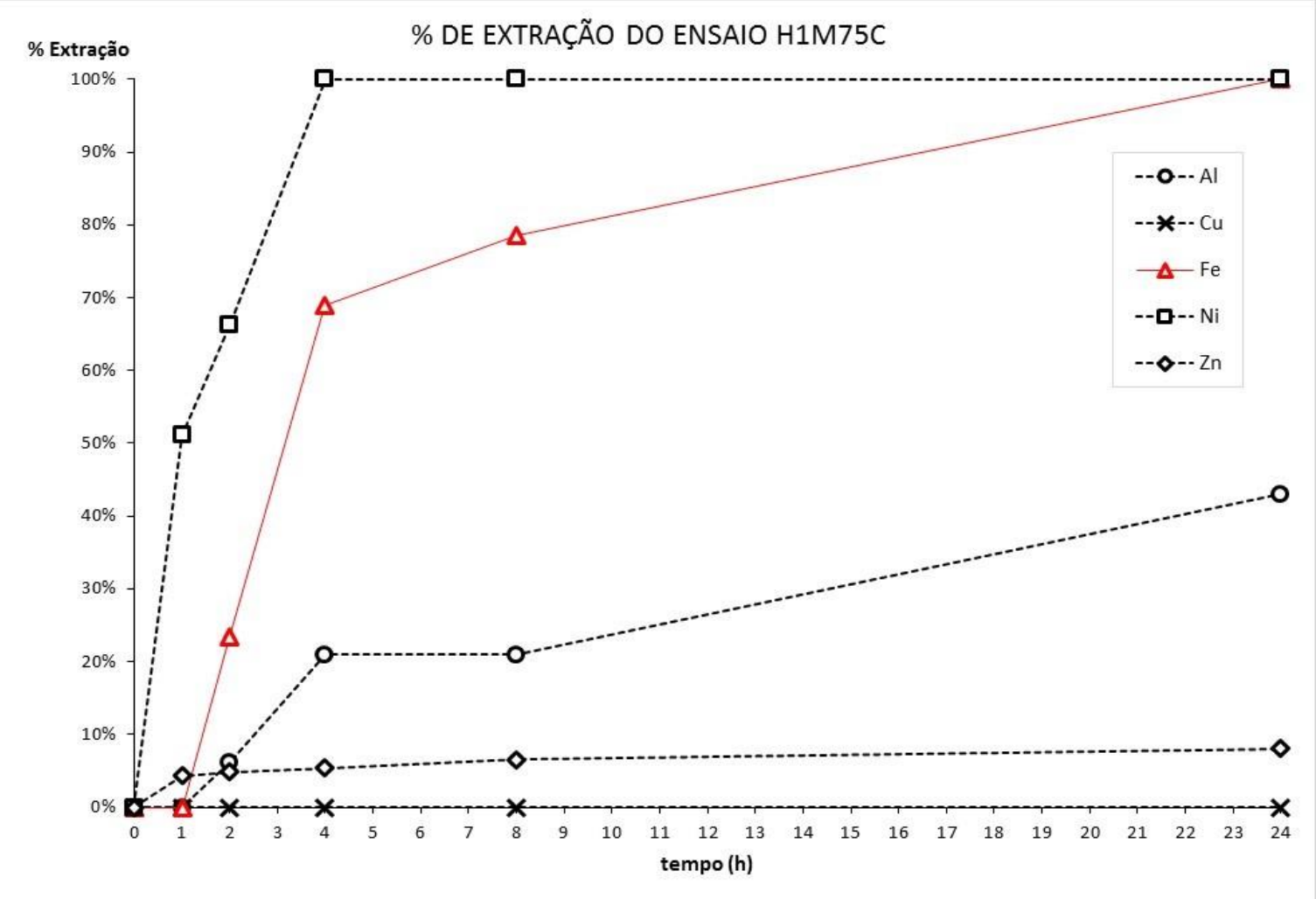

Figura 25 - Resultados da lixiviação do ensaio H1M75C.

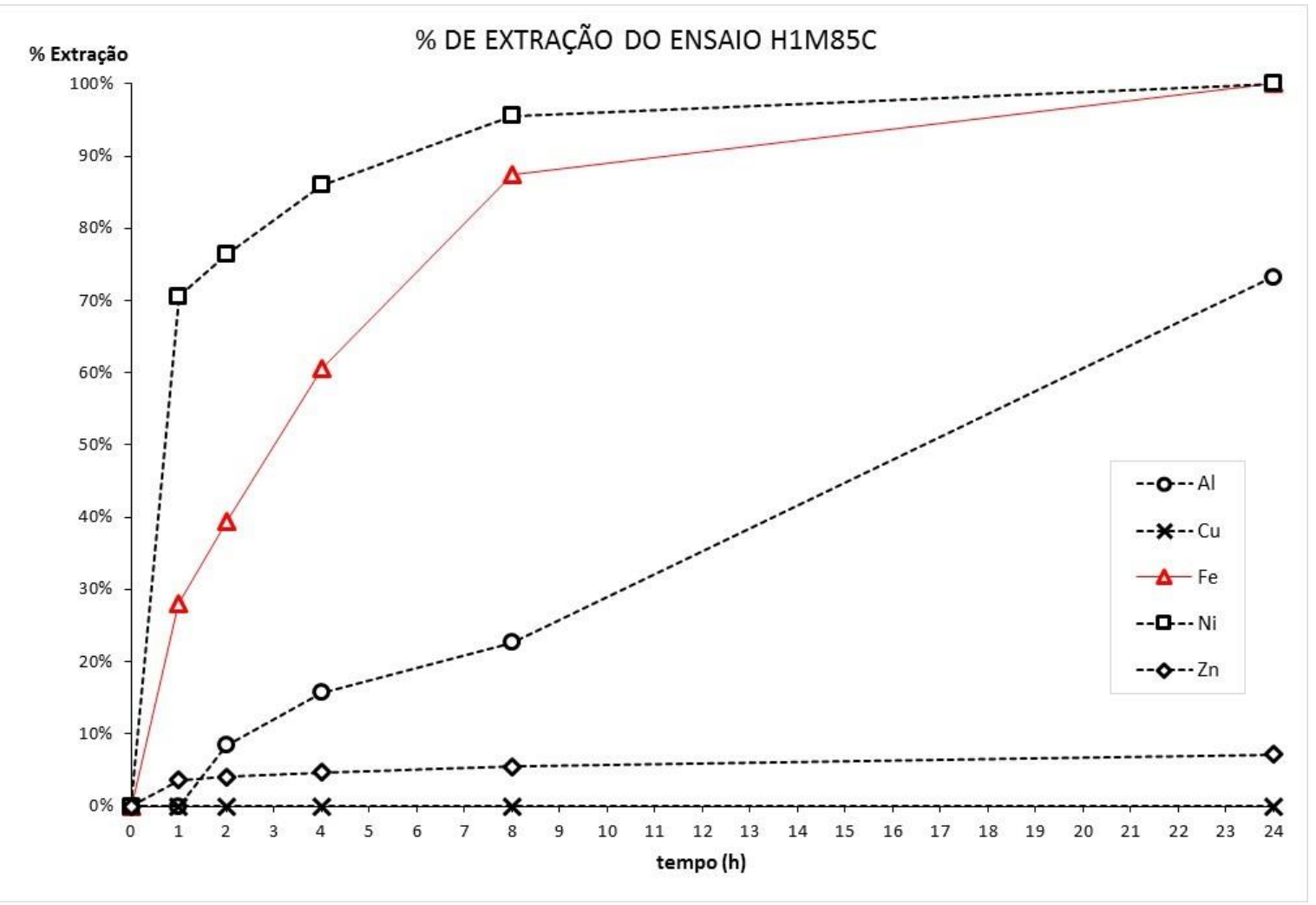

Figura 26 - Resultados da lixiviação do ensaio H1M85C. 


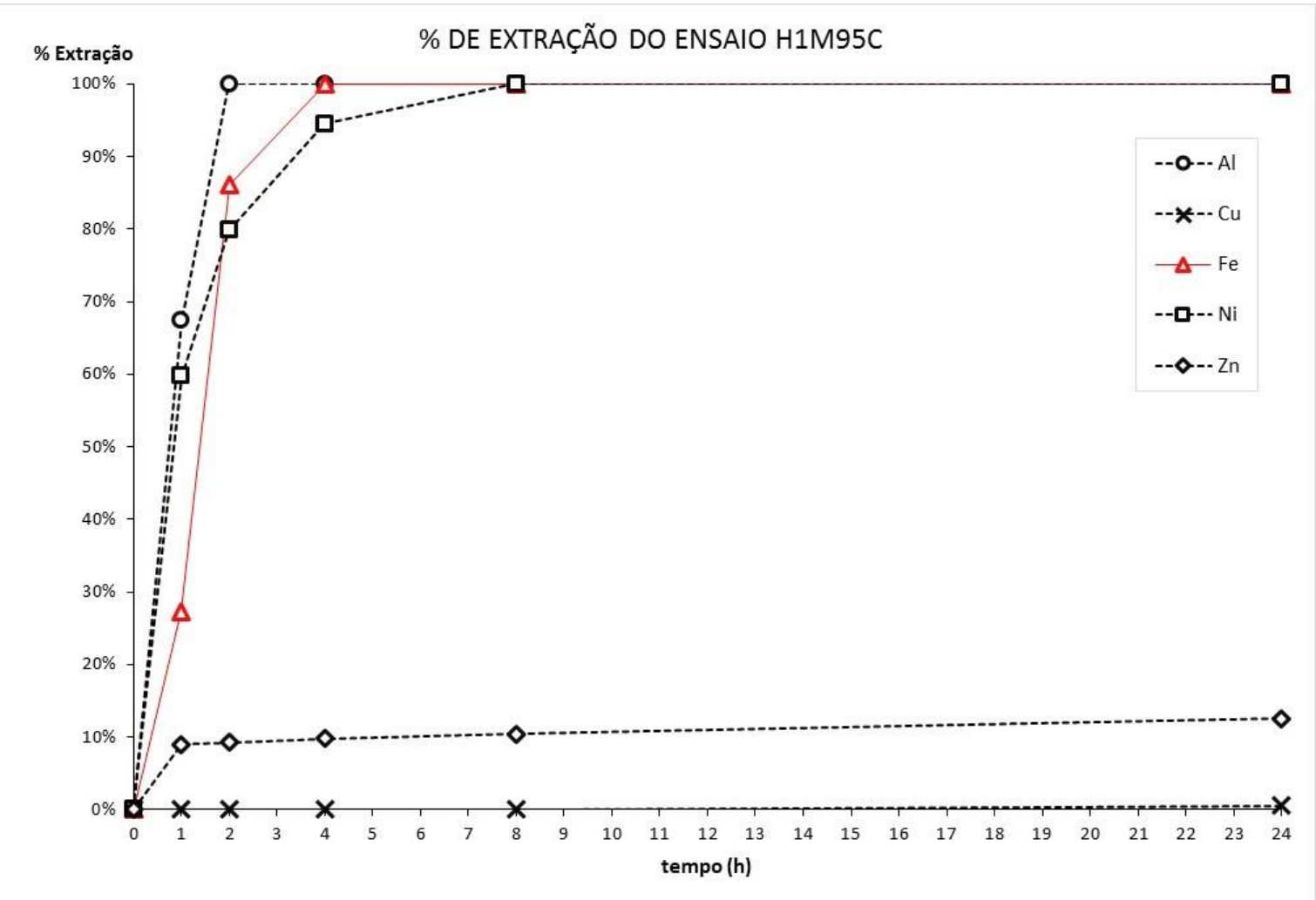

Figura 27 - Resultados da lixiviação do ensaio H1M95C.

Estas figuras mostram que não foi possível recuperar cobre sob nenhuma das condições dos ensaios. O único vestígio encontrado $(0,6 \%)$ foi identificado no ensaio realizado à temperatura de $95^{\circ} \mathrm{C}$, somente na alíquota de 24 horas. De fato, o cobre é um elemento mais nobre que outros metais - como por exemplo o ferro - e desta forma não será extraído sem a presença de um agente oxidante (como por exemplo o peróxido de hidrogênio) ou outros elementos que alterem as condições químicas do ensaio, como por exemplo o $\mathrm{pH}$.

Avaliou-se o comportamento da extração de cada um dos metais analisados, cujos resultados são apresentados na Tabela 13. 
Tabela 13 - Quadro das condições de extração dos metais alumínio, cobre, ferro, níquel e zinco presentes nas amostras, analisados individualmente nos ensaio com ácido sulfúrico à concentração de $1 \mathrm{~mol} / \mathrm{L}$.

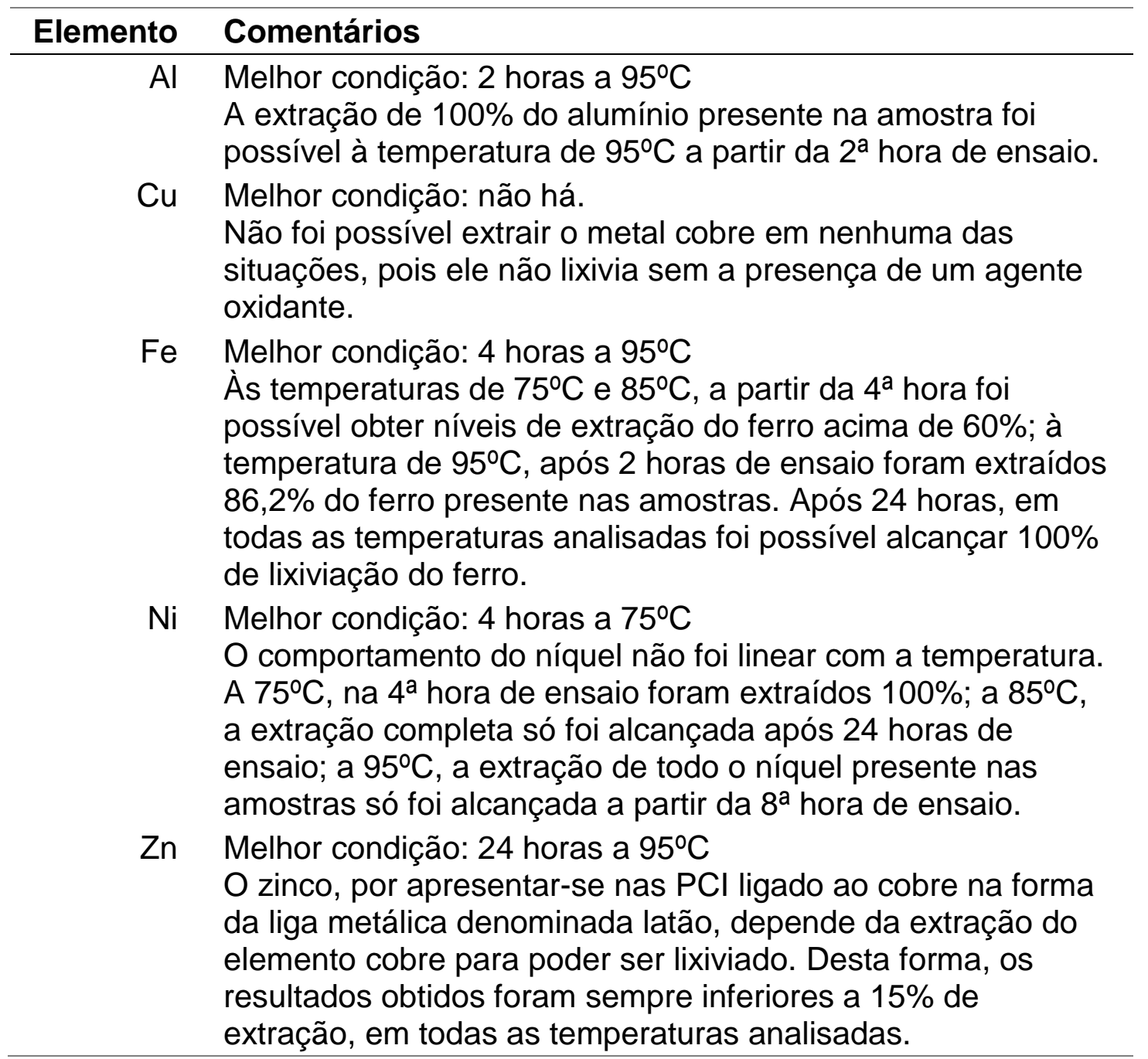

No caso dos ensaios realizados com ácido sulfúrico a $2 \mathrm{~mol} / \mathrm{L}$, os valores de extração destes mesmos metais são apresentados na Tabela 14. 
Tabela 14 - Resultados dos ensaios de extração de metais em ácido sulfúrico $2 \mathrm{~mol} / \mathrm{L}$ em 24 horas a diferentes temperaturas, em porcentagens em massa.

\begin{tabular}{|c|c|c|c|c|c|c|}
\hline \# & $t(h)$ & Al (\%) & $\mathrm{Cu}(\%)$ & $\mathrm{Fe}(\%)$ & $\mathrm{Ni}(\%)$ & $\mathrm{Zn} \mathrm{( \% )}$ \\
\hline \multirow{6}{*}{$\begin{array}{l}0 \\
\text { N } \\
\sum_{N}^{N} \\
\text { T }\end{array}$} & $\mathrm{Oh}$ & 0,0 & 0,0 & 0,0 & 0,0 & 0,0 \\
\hline & $1 \mathrm{~h}$ & 50,9 & 0,0 & 49,0 & 0,0 & 2,9 \\
\hline & $2 \mathrm{~h}$ & 76,1 & 0,0 & 64,7 & 0,0 & 3,3 \\
\hline & $4 \mathrm{~h}$ & 88,9 & 0,0 & 66,8 & 0,0 & 3,4 \\
\hline & $8 \mathrm{~h}$ & 96,4 & 0,1 & 68,3 & 1,4 & 3,4 \\
\hline & $24 \mathrm{~h}$ & 100,0 & 0,1 & 65,9 & 31,0 & 3,3 \\
\hline \multirow{6}{*}{ 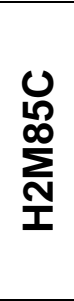 } & $\mathrm{Oh}$ & 0,0 & 0,0 & 0,0 & 0,0 & 0,0 \\
\hline & $1 \mathrm{~h}$ & 67,1 & 0,0 & 56,4 & 0,0 & 2,9 \\
\hline & $2 \mathrm{~h}$ & 86,3 & 0,1 & 65,0 & 0,0 & 3,2 \\
\hline & $4 \mathrm{~h}$ & 100,0 & 0,1 & 71,3 & 11,7 & 3,5 \\
\hline & $8 \mathrm{~h}$ & 100,0 & 0,1 & 100,0 & 38,6 & 3,5 \\
\hline & $24 \mathrm{~h}$ & 100,0 & 0,2 & 100,0 & 83,9 & 3,3 \\
\hline \multirow{6}{*}{ 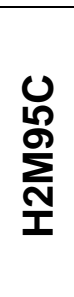 } & $\mathrm{Oh}$ & 0,0 & 0,0 & 0,0 & 0,0 & 0,0 \\
\hline & $1 \mathrm{~h}$ & 80,9 & 0,0 & 96,2 & 3,0 & 6,0 \\
\hline & $2 \mathrm{~h}$ & 96,7 & 0,1 & 100,0 & 20,4 & 6,5 \\
\hline & $4 h$ & 100,0 & 0,0 & 100,0 & 47,6 & 6,7 \\
\hline & $8 \mathrm{~h}$ & 100,0 & 0,2 & 100,0 & 100,0 & 6,7 \\
\hline & $24 \mathrm{~h}$ & 100,0 & 0,2 & 100,0 & 100,0 & 5,9 \\
\hline
\end{tabular}

Quando exposto à solução de ácido sulfúrico na concentração de $2 \mathrm{~mol} / \mathrm{L}$, analogamente aos ensaios com ácido sulfúrico na concentração de $1 \mathrm{~mol} / \mathrm{L}$, observouse um aumento crescente na dissolução dos metais alumínio, ferro e zinco: novamente, quanto maior a temperatura e quanto maior o tempo de exposição aos agentes lixiviantes, maior é a eficiência na extração destes metais.

Entretanto, a eficiência do processo de lixiviação sofreu algumas alterações quando comparado aos ensaios realizados com ácido a $1 \mathrm{~mol} / \mathrm{L}$.

$\mathrm{Na}$ Figura 28, na Figura 29 e na Figura 30, os mesmos elementos são apresentados à concentração de ácido sulfúrico de $2 \mathrm{~mol} / \mathrm{L}$ nas temperaturas de $75^{\circ} \mathrm{C}$, $85^{\circ} \mathrm{C}$ e $95^{\circ} \mathrm{C}$, respectivamente. 


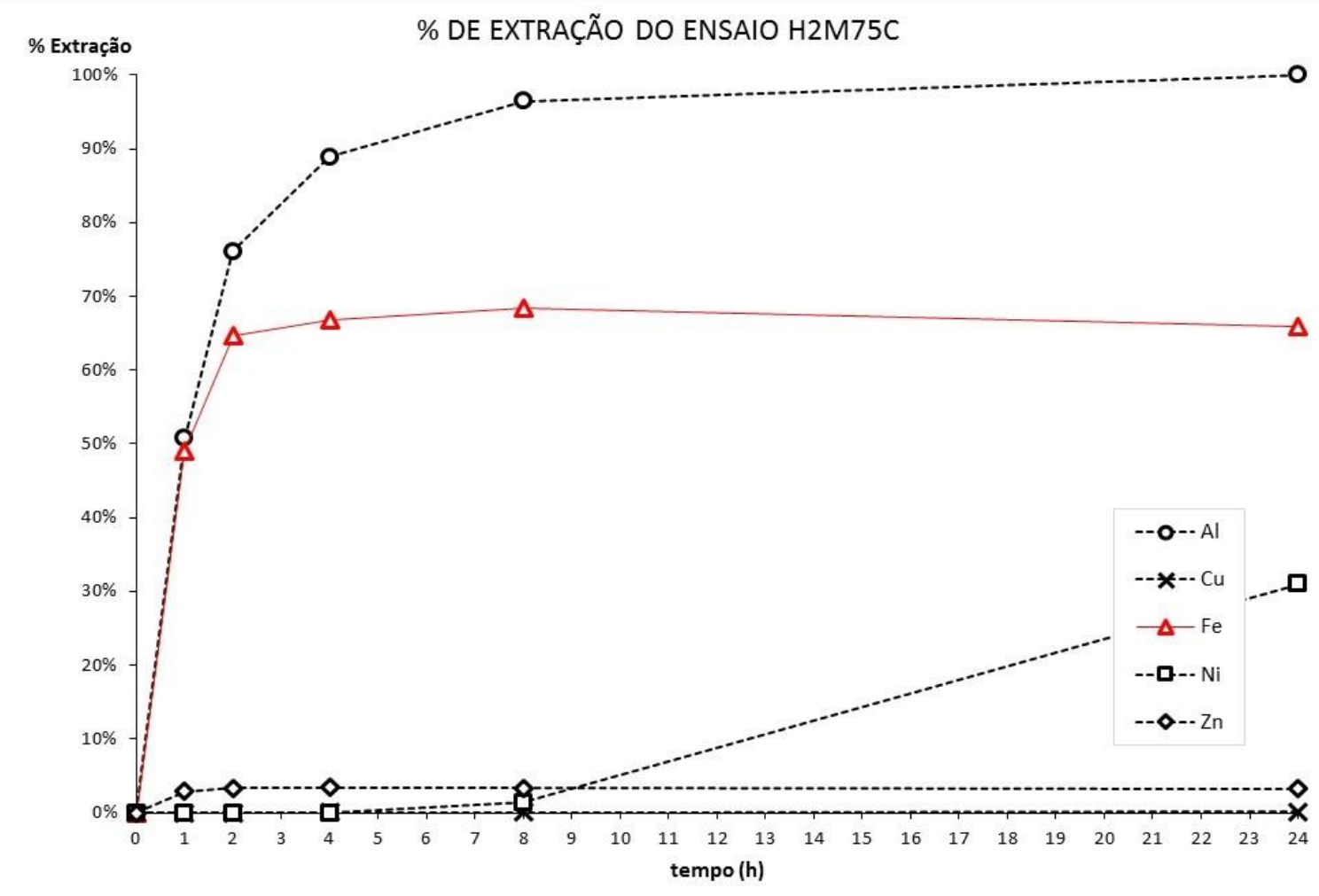

Figura 28 - Resultados da lixiviação do ensaio H2M75C.

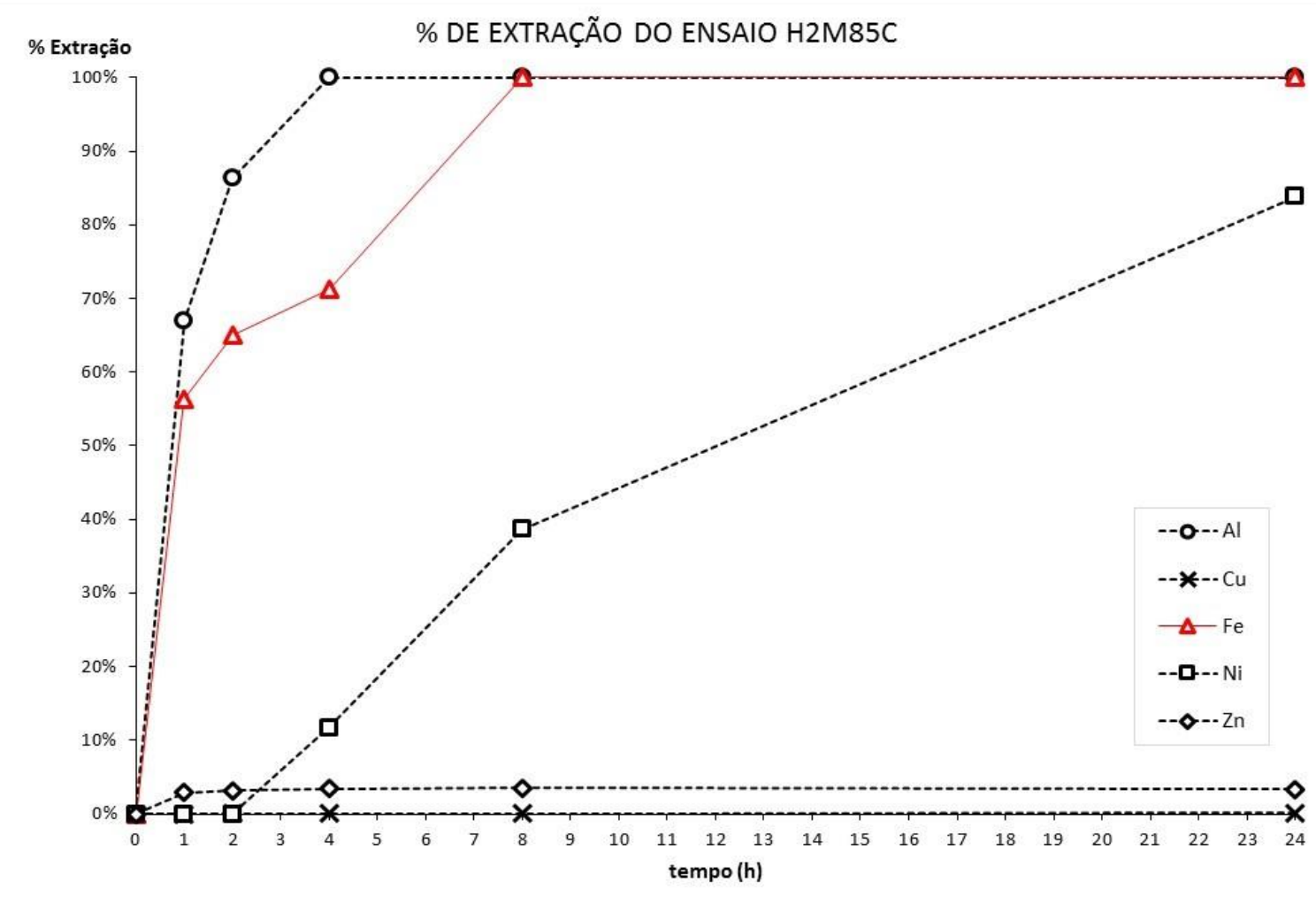

Figura 29 - Resultados da lixiviação do ensaio H2M85C. 


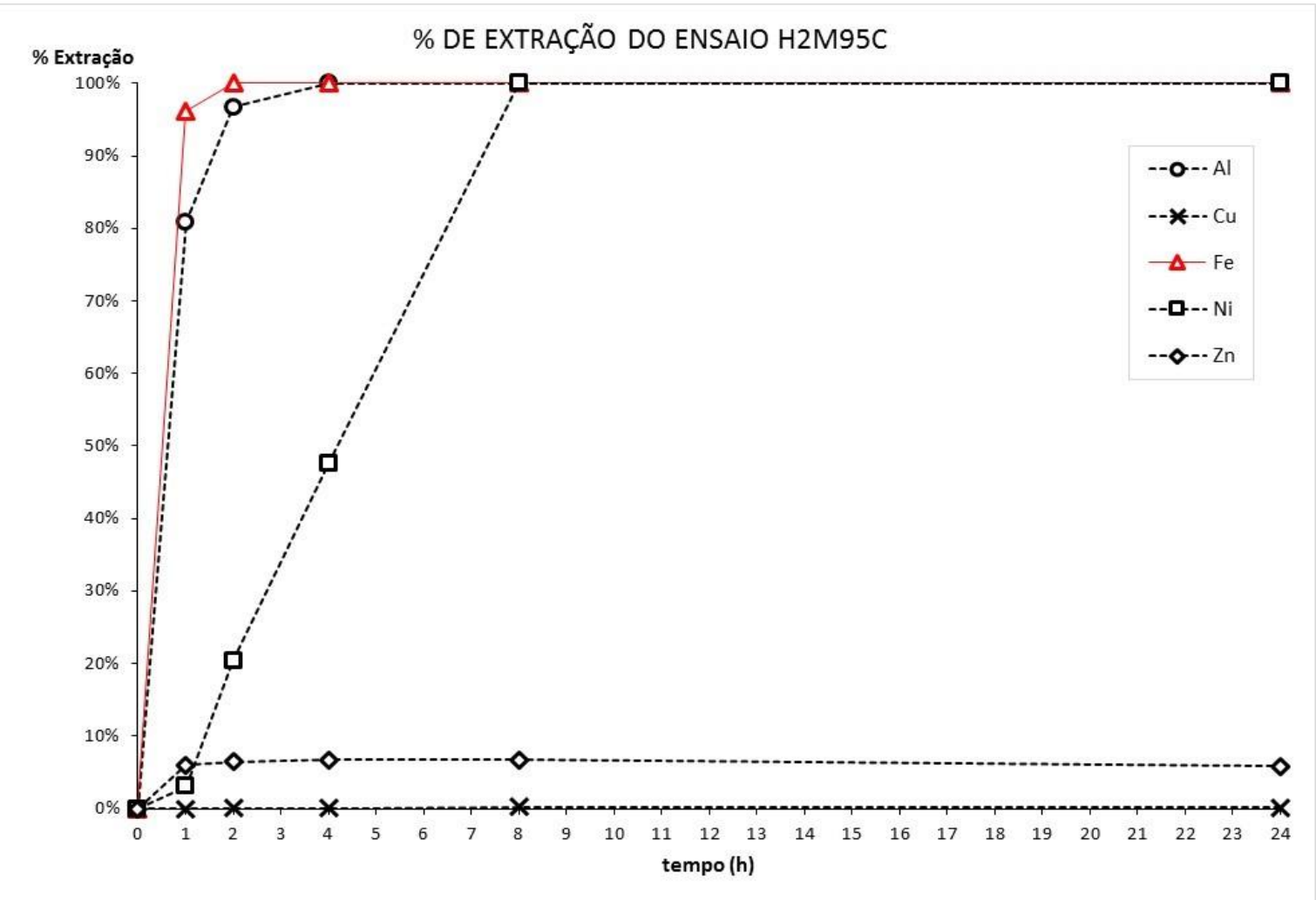

Figura 30 - Resultados da lixiviação do ensaio H2M95C.

Nos ensaios com ácido em concentração de $2 \mathrm{~mol} / \mathrm{L}$, a taxa de extração do níquel mostrou-se mais influenciada pela temperatura. A $95^{\circ} \mathrm{C}$ houve $100 \%$ de recuperação na oitava hora de ensaio; a 85ํㅡ mesmo após 24 horas de ensaio não houve recuperação total; a $75^{\circ} \mathrm{C}$ até a oitava hora de ensaio o percentual de extração era inferior a $5 \%$.

Desta forma, avaliou-se o comportamento da extração de cada um dos metais analisados; os resultados são apresentados na Tabela 15. 
Tabela 15 - Quadro das condições de extração dos metais alumínio, cobre, ferro, níquel e zinco presentes nas amostras, analisados individualmente nos ensaios com ácido sulfúrico à concentração de $2 \mathrm{~mol} / \mathrm{L}$.

\begin{tabular}{|c|c|}
\hline Elemento & Comentários \\
\hline $\mathrm{Al}$ & $\begin{array}{l}\text { Melhor condição: } 4 \text { horas a } 85^{\circ} \mathrm{C} \\
\text { A extração de } 100 \% \text { do alumínio presente na amostra foi } \\
\text { alcançada às temperaturas de } 85^{\circ} \mathrm{C} \text { e } 95^{\circ} \mathrm{C} \text { a partir da } 4^{\underline{a}} \\
\text { hora de ensaio. }\end{array}$ \\
\hline $\mathrm{Cu}$ & $\begin{array}{l}\text { Melhor condição: não há. } \\
\text { Não foi possível extrair o metal cobre em nenhuma das } \\
\text { situações, pois ele não lixivia sem a presença de um agente } \\
\text { oxidante. }\end{array}$ \\
\hline $\mathrm{Fe}$ & $\begin{array}{l}\text { Melhor condição: } 2 \text { horas a } 95^{\circ} \mathrm{C} \\
\text { À } 75^{\circ} \mathrm{C} \text { não foi possível extrair todo o ferro presente nas } \\
\text { amostras; a } 85^{\circ} \mathrm{C} \text { isto ocorreu a partir da } 8^{\mathrm{a}} \text { hora; a } 95^{\circ} \mathrm{C} \text {, } \\
\text { após } 2 \text { horas de ensaio. Diferentemente do ensaio a } 1 \mathrm{M} \text {, } \\
\text { mesmo após } 24 \text { horas de exposição ao agente lixiviante, na } \\
\text { temperatura de } 75^{\circ} \mathrm{C} \text { não foi possível alcançar } 100 \% \text { de } \\
\text { extração do ferro. }\end{array}$ \\
\hline $\mathrm{Ni}$ & $\begin{array}{l}\text { Melhor condição: } 8 \text { horas a } 95^{\circ} \mathrm{C} \\
\text { A completa extração do níquel só foi alcançada no ensaio a } \\
95^{\circ} \mathrm{C} \text {, a partir da } 8^{\mathrm{a}} \text { hora de ensaio. }\end{array}$ \\
\hline $\mathrm{Zn}$ & $\begin{array}{l}\text { Melhor condição: } 4 \text { horas a } 95^{\circ} \mathrm{C} \\
\text { O zinco, por apresentar-se em grande parte na forma de } \\
\text { latão, depende da extração do cobre para poder ser } \\
\text { lixiviado. Os resultados de extração obtidos nestes ensaios } \\
\text { foram sempre inferiores a } 7 \% \text {, em todas as temperaturas } \\
\text { analisadas. }\end{array}$ \\
\hline
\end{tabular}

Considerando que este estudo tem por objetivo a extração máxima do elemento ferro presente nas $\mathrm{PCl}$ buscando assim uma alternativa ao processo de separação magnética na reciclagem de resíduos de equipamentos eletroeletrônicos, o ensaio que produziu efeitos mais significativos foi o ensaio com ácido sulfúrico na concentração de $2 \mathrm{~mol} / \mathrm{L}$ a 95으 (H2M95C) pelo tempo de 2 horas, sendo esta a condição de menor tempo na qual $100 \%$ do ferro presentes na amostra foram lixiviados.

Para possibilitar uma análise mais detalhada e buscar uma melhor compreensão dos resultados, foram desenhadas as curvas de extração pelo tempo para cada um dos seis elementos estudados separadamente (alumínio, cobre, ferro, níquel e zinco). 
As curvas apresentadas na Figura 31 à Figura 35 representam o comportamento dos metais alumínio, cobre, ferro, níquel e zinco em cada um dos ensaios realizados.

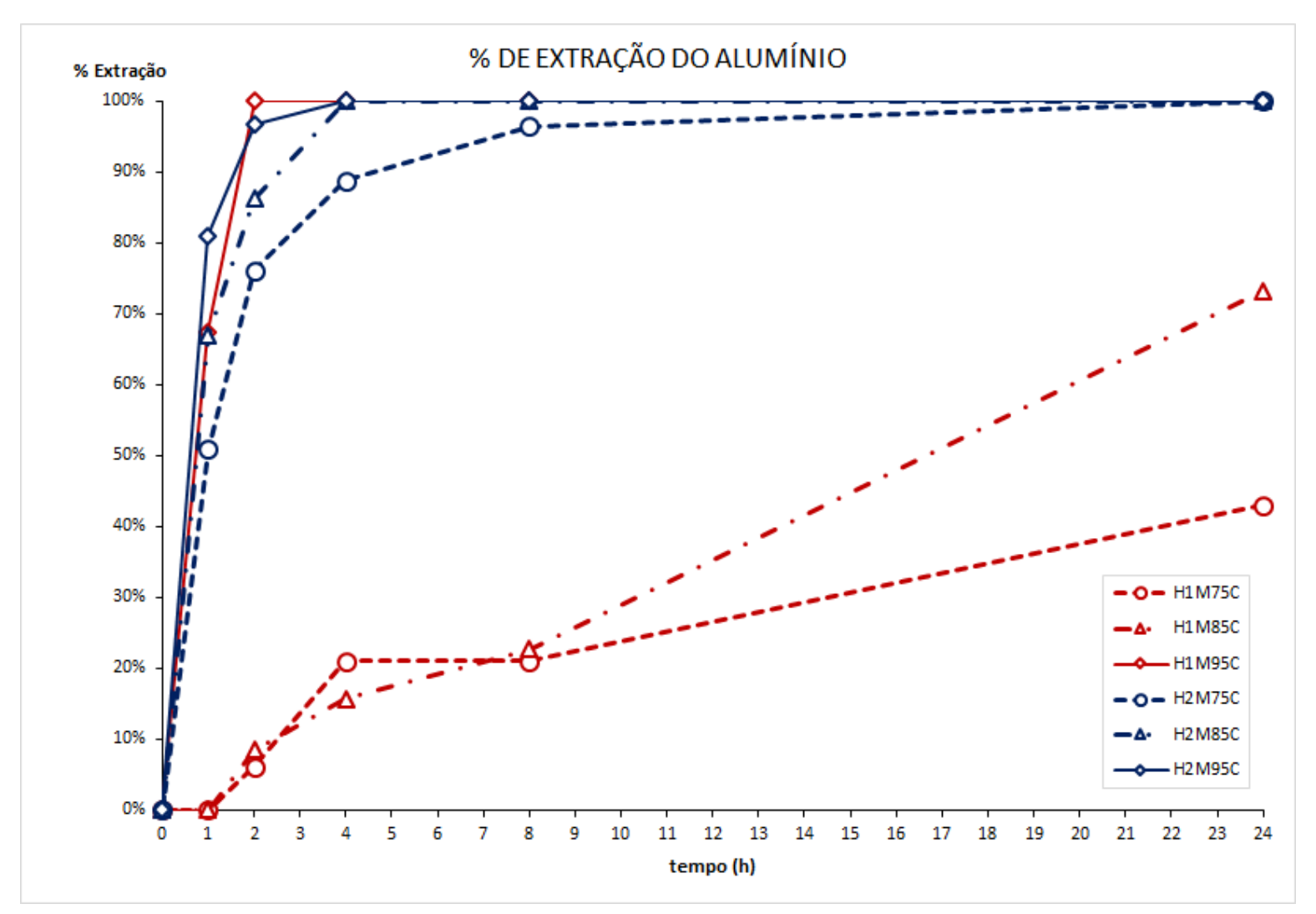

Figura 31 - Resultados da lixiviação do alumínio.

A Figura 31 mostra que o ensaio que obteve mais rapidamente $100 \%$ de extração do alumínio foi o ensaio $\mathrm{H} 1 \mathrm{M} 95 \mathrm{C}$, que precisou de 2 horas para atingir tal resultado. Observou-se, entretanto, que neste mesmo tempo, o ensaio H2M95C alcançou cerca de $97 \%$ de extração deste metal.

Com exceção dos ensaios H1M75C e H1M85C, todos os outros alcançaram 100\% de extração após 24 horas de ensaio. O pior resultado foi do ensaio H1M75C, com $43 \%$ de extração em massa de alumínio após 24 horas. 


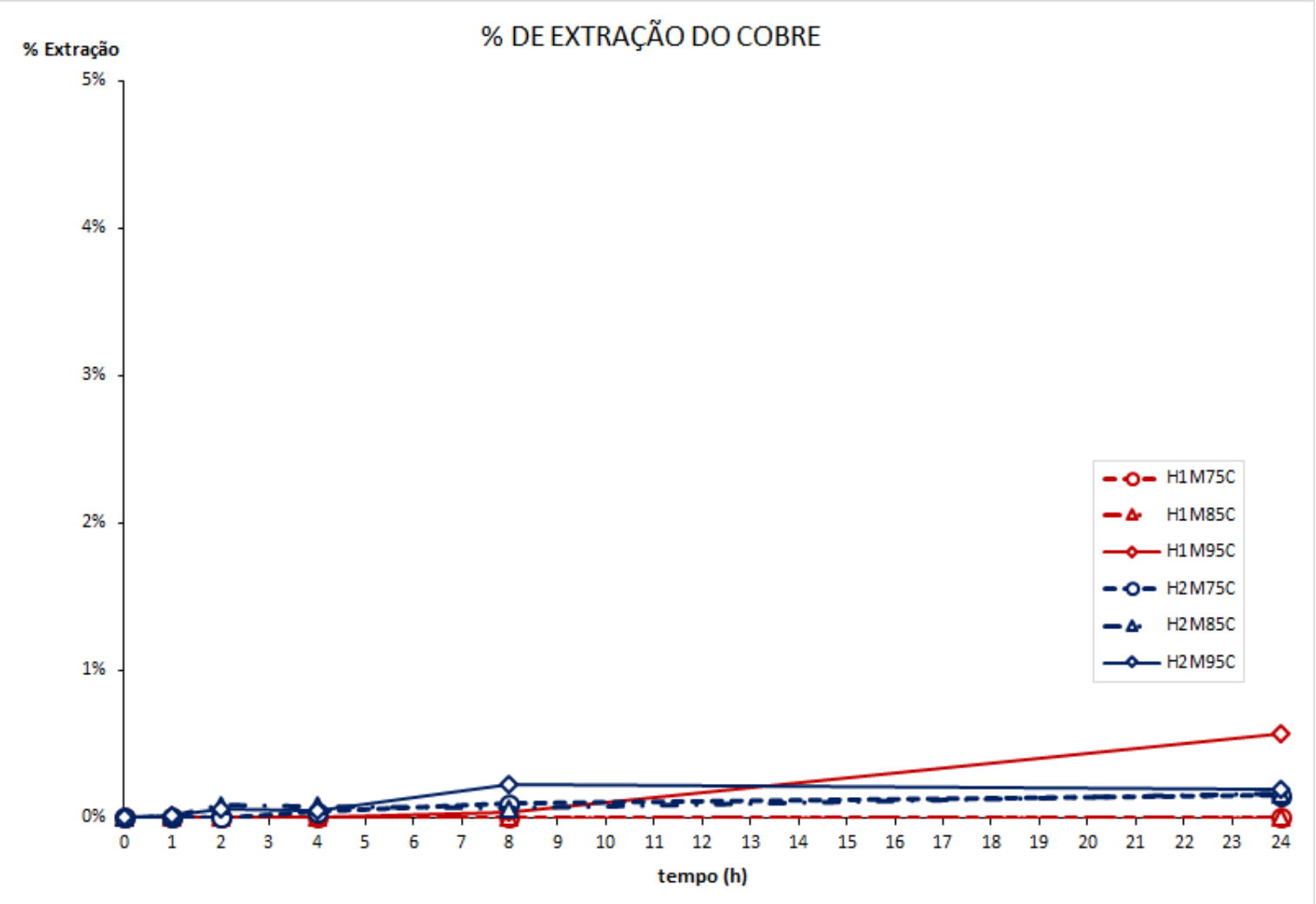

Figura 32 - Resultados da lixiviação do cobre.

A Figura 32 indica que em nenhum dos ensaios realizados foi possível atingir mais que $1 \%$ de extração do cobre presente nas amostras.

O melhor resultado foi obtido no ensaio $\mathrm{H} 1 \mathrm{M} 95 \mathrm{C}$, com $0,6 \%$ de extração após 24 horas de ensaio. Nos outros ensaios, o valor máximo de extração chegou a 0,2\% (H2M85C e H2M95C), 0,1\% (H2M75C) até 0\% (H1M75C e H1M85C).

Logo, é possível concluir que nas condições dos ensaios o cobre presente nas amostras não reagiu. 


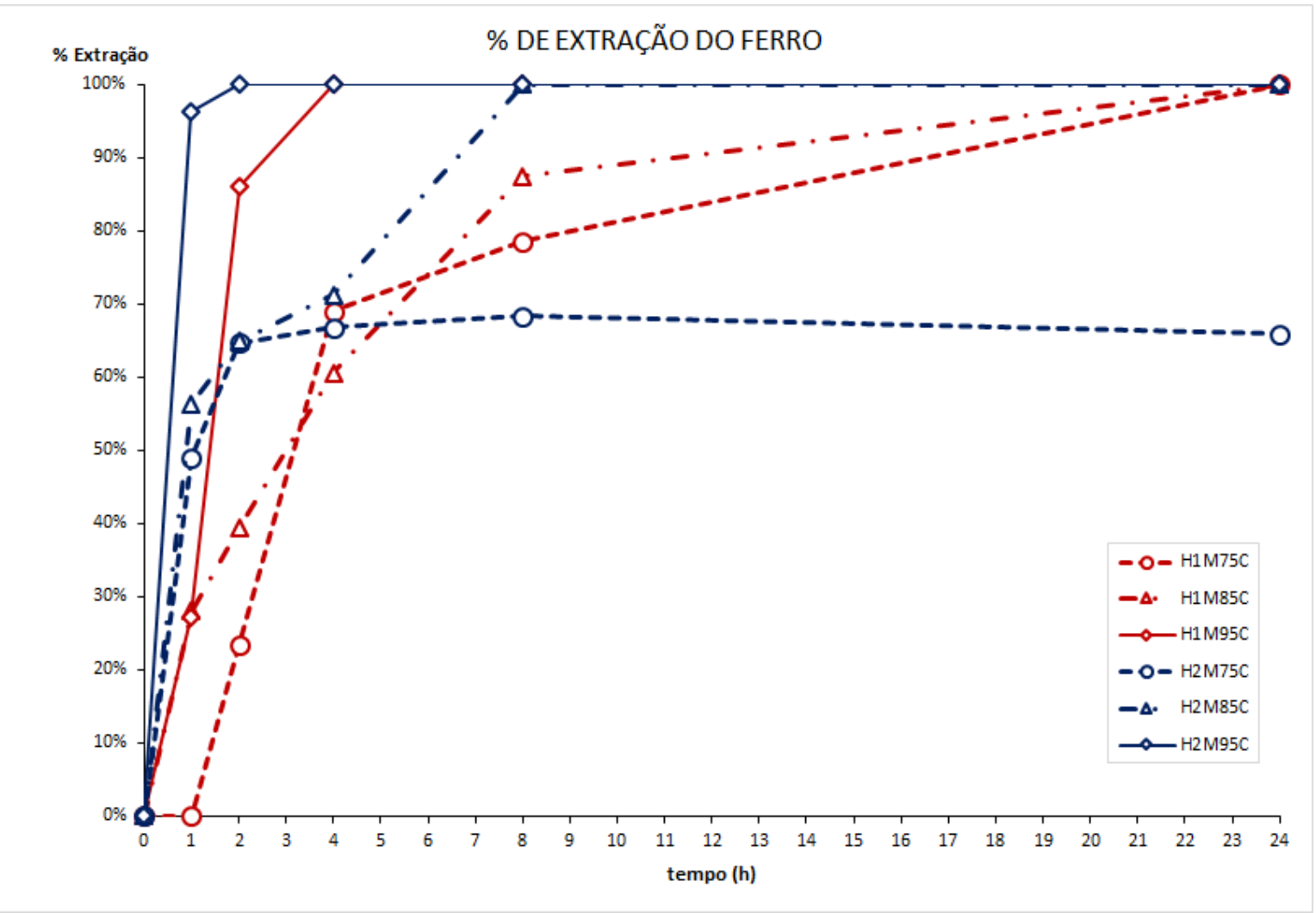

Figura 33 - Resultados da lixiviação do ferro.

A Figura 33 mostra o comportamento do ferro nos diferentes ensaios realizados, no qual é possível observar que, com exceção do ensaio H2M75C, todos os ensaios obtiveram $100 \%$ de extração após 24 horas.

Destaca-se o ensaio H2M95C, que obteve $96,2 \%$ de extração na primeira hora, e $100 \%$ na segunda.

Observa-se também que o ensaio H1M95C obteve 100\% de extração na quarta hora de ensaio.

Por outro lado, o ensaio H1M75C atingiu o patamar de aproximadamente $65 \%$ de extração na segunda hora e assim permaneceu até o final do ensaio, indicando uma possível saturação do processo ou o término do ferro disponível para lixiviação. 


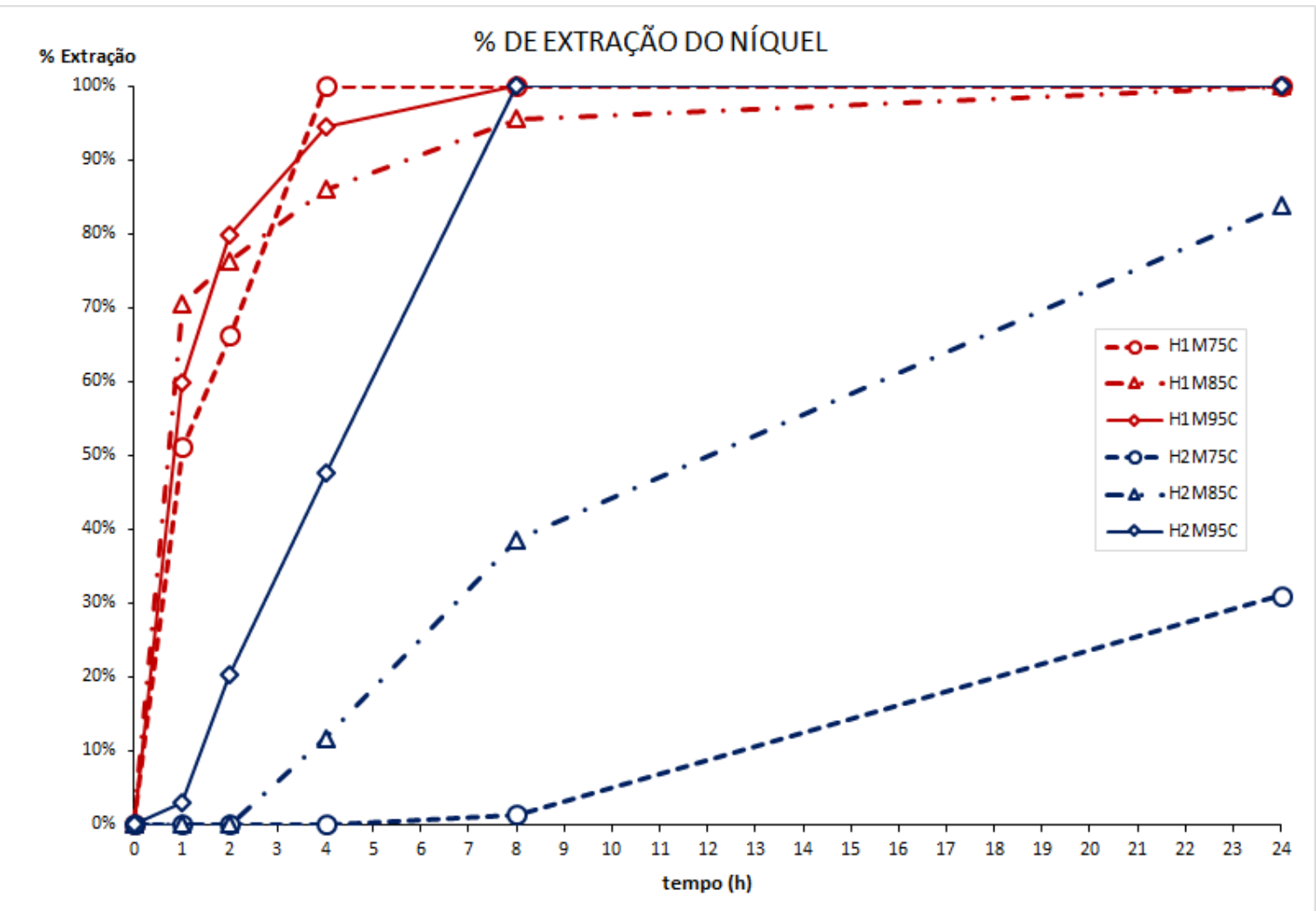

Figura 34 - Resultados da lixiviação do níquel.

Na Figura 34 é possível observar que o ensaio que atingiu 100\% de extração do níquel no menor tempo foi o $\mathrm{H} 1 \mathrm{M} 75 \mathrm{C}$, com 4 horas. Na sequência - na oitava hora do início do processo - ficaram os ensaios H1M95C e H2M95C, que também alcançaram $100 \%$ de extração.

Nota-se ainda que os ensaios H2M75C e H2M85C não alcançaram 100\% de extração mesmo após 24 horas, tampouco atingiram um patamar de estabilidade. 


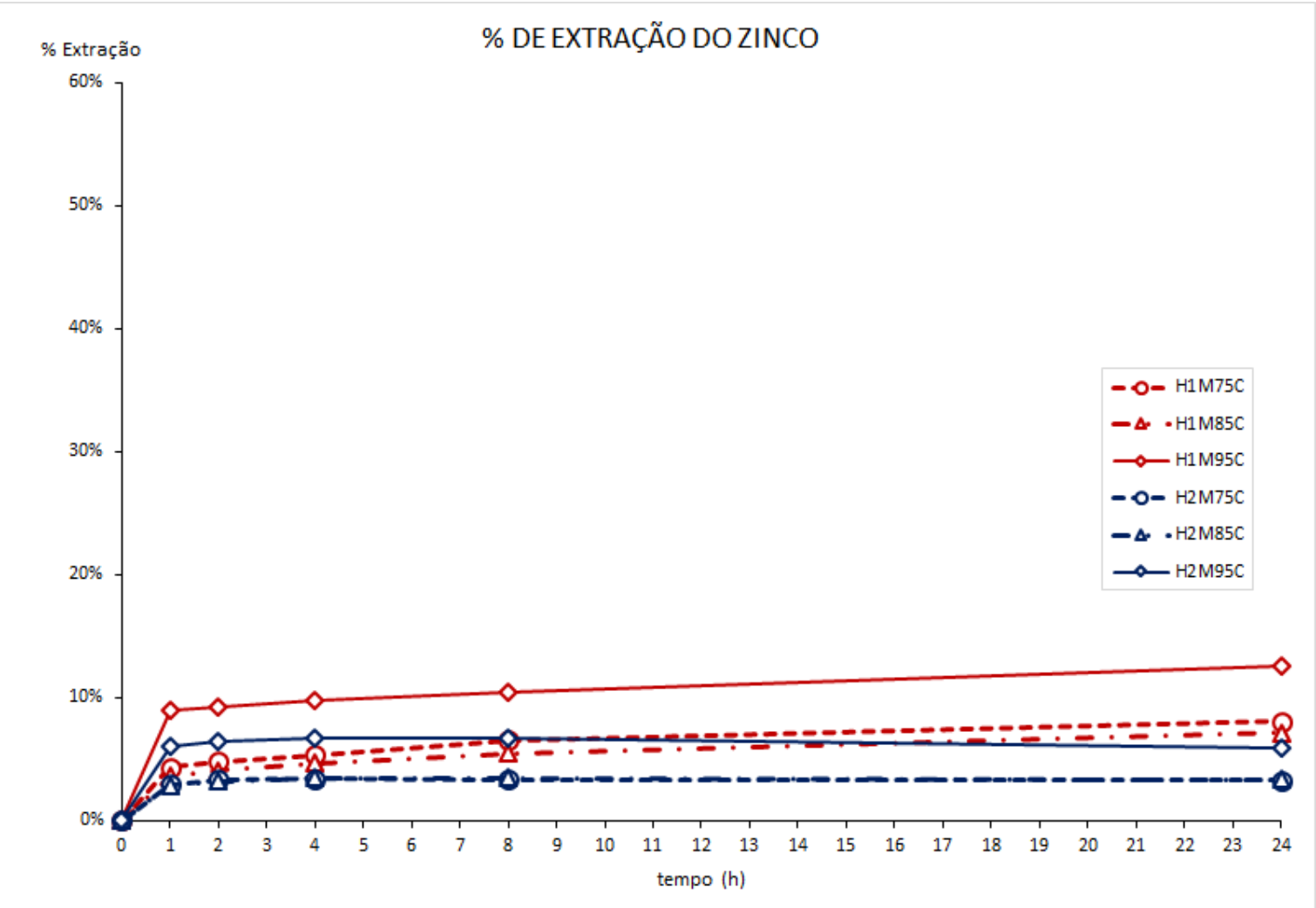

Figura 35 - Resultados da lixiviação do zinco.

A Figura 35 mostra que, independentemente do ensaio realizado, passada a primeira hora os índices de extração de zinco praticamente se estabilizaram.

O ensaio $\mathrm{H} 1 \mathrm{M} 95 \mathrm{C}$ foi o que obteve melhores resultados, com $9,0 \%$ de extração na primeira hora de ensaio e $12,5 \%$ após 24 horas. 


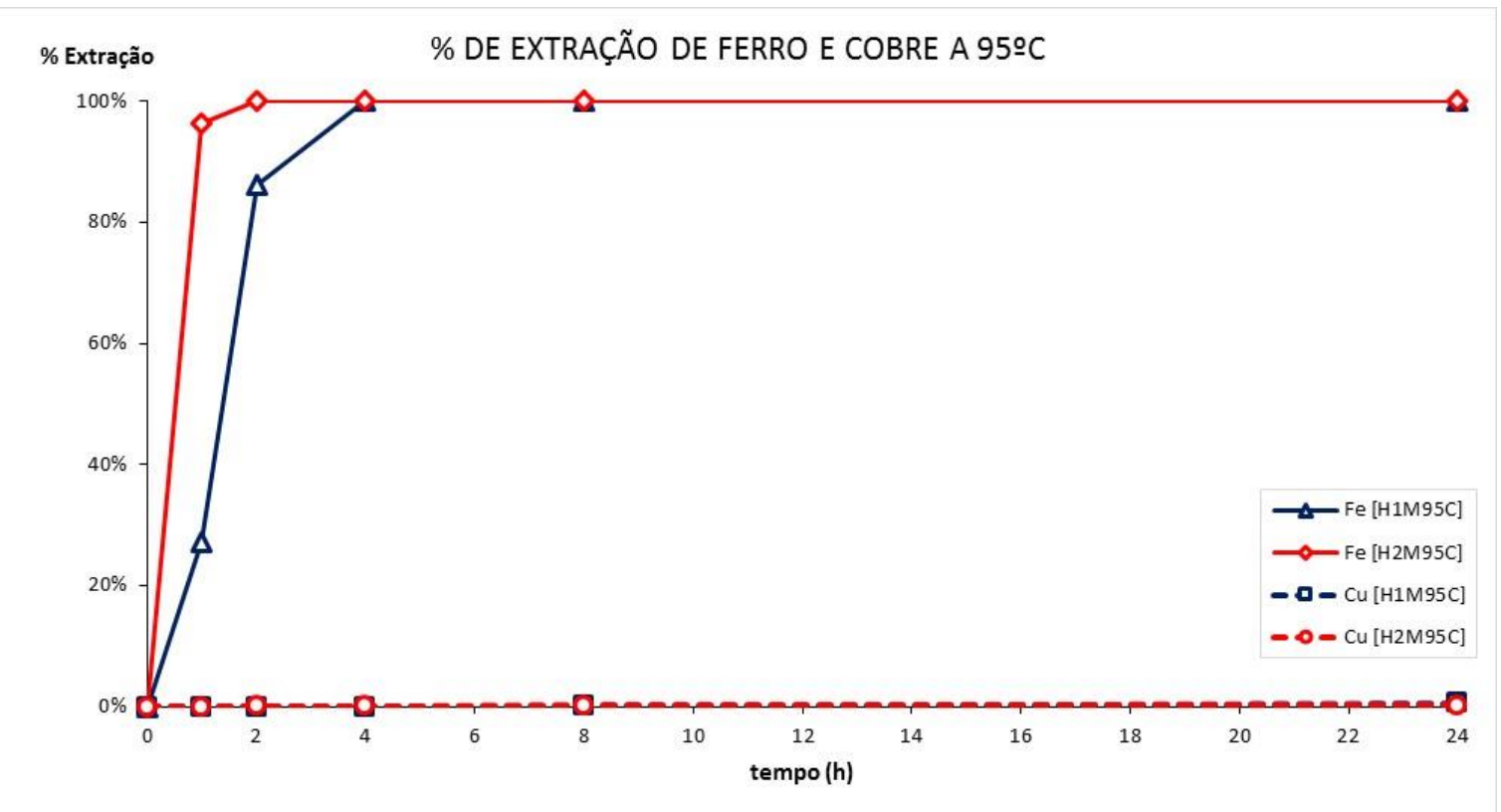

Figura 36 - Comparativo da extração do ferro e do cobre a 95ㄷ.

A partir da Figura 36 conclui-se que, a $95^{\circ} \mathrm{C}$ e para efeitos de separação entre o ferro e o cobre presentes nas amostras, o tempo necessário para que houvesse 99,9\% de rendimento no processo de separação foi de 2 horas com o uso de ácido sulfúrico $2 \mathrm{~mol} / \mathrm{L}$.

Além disto, ao completarem 4 horas, ambos os ensaios alcançam 100\% de rendimento. Desta forma, com 4 horas de ensaio é possível afirmar que o rendimento do processo de separação entre ferro e cobre independe da concentração do ácido utilizado.

De uma forma geral, observa-se a partir destes resultados que o processo de lixiviação ácida consegue extrair com sucesso 100\% do ferro presente nas amostras de $\mathrm{PCl}$ logo nas primeiras horas do procedimento, ao mesmo tempo em que a extração do cobre não chega a $1 \%$.

Considerando que a eficiência da separação do ferro em processo de separação magnética é de 99\%, e a do cobre de 92\% (CORREA, 2015), a lixiviação é portanto, uma alternativa ao processo de separação magnética, com separação do ferro com $100 \%$ e do cobre com $99 \%$ de rendimento. 


\subsection{DIAGRAMAS DE POURBAIX}

Foram calculados os Diagramas de Pourbaix para o ferro nas temperaturas de $75^{\circ} \mathrm{C}, 85^{\circ} \mathrm{C}$ e $95^{\circ} \mathrm{C}$ com o auxílio do programa "HSC Chemistry"; os resultados são apresentados na Figura 37, na Figura 38 e na Figura 39, respectivamente.

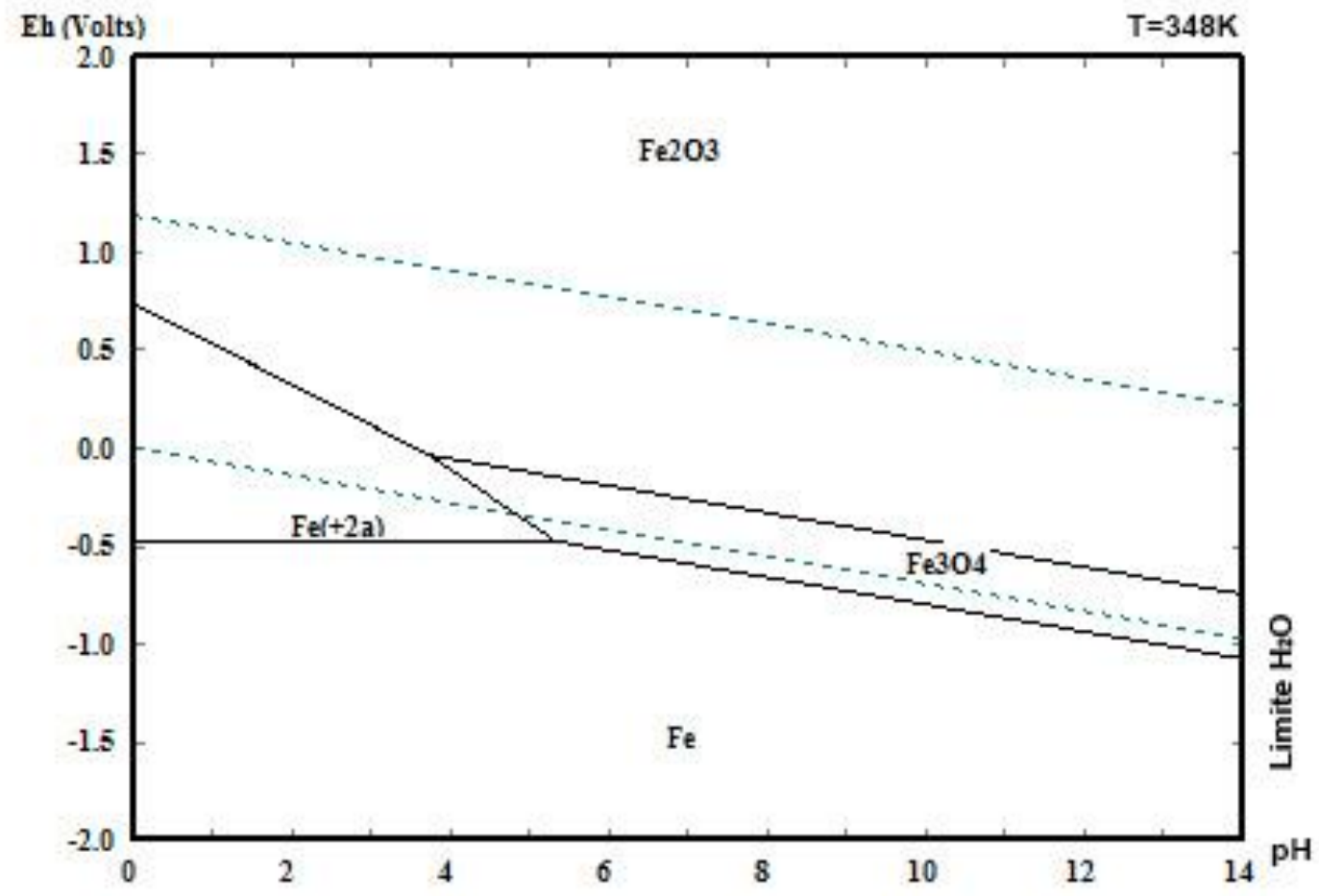

Figura 37 - Diagrama de Pourbaix para o ferro em meio aquoso para a temperatura de $75^{\circ} \mathrm{C}$. 


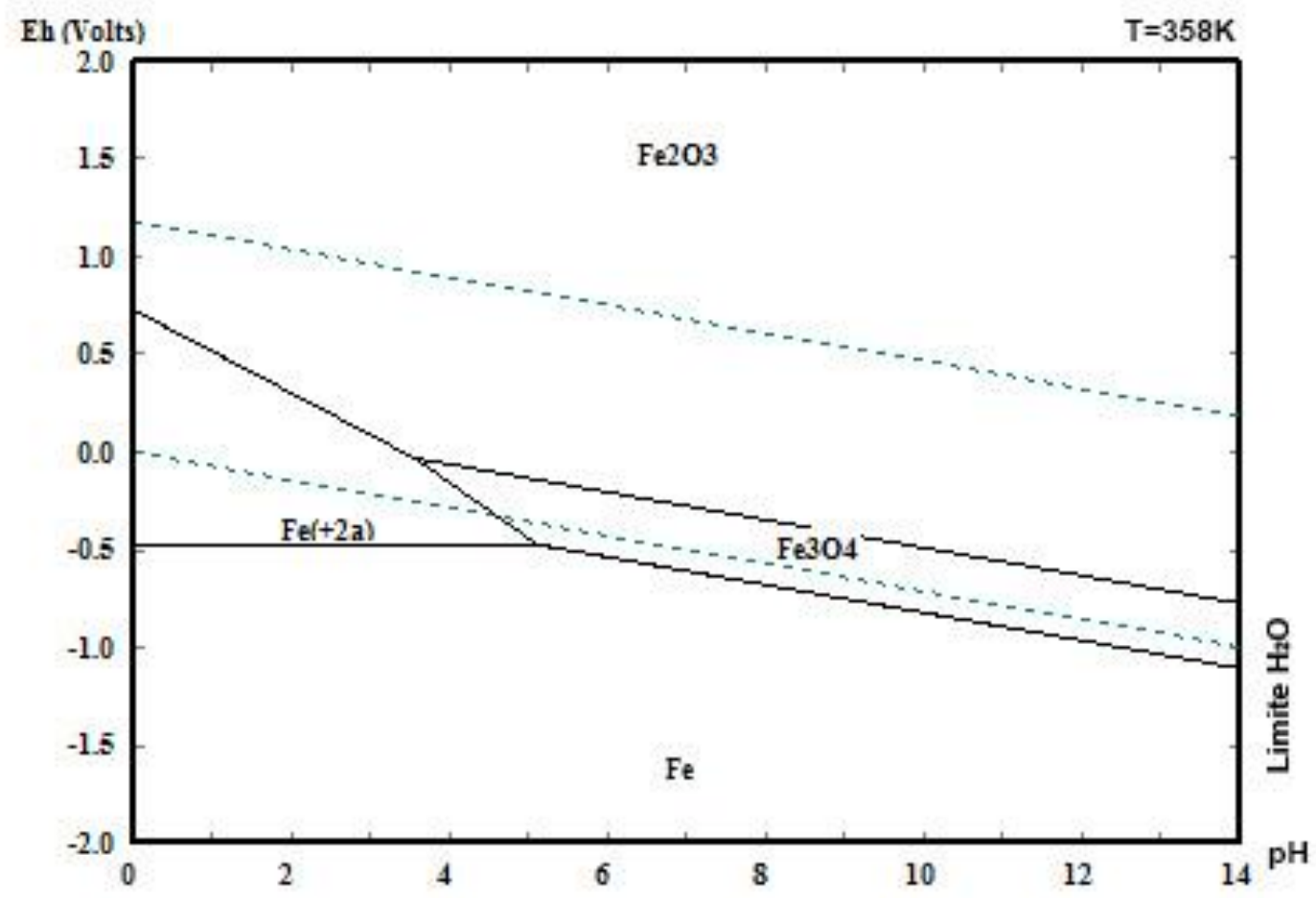

Figura 38 - Diagrama de Pourbaix para o ferro em meio aquoso para a temperatura de $85^{\circ} \mathrm{C}$.

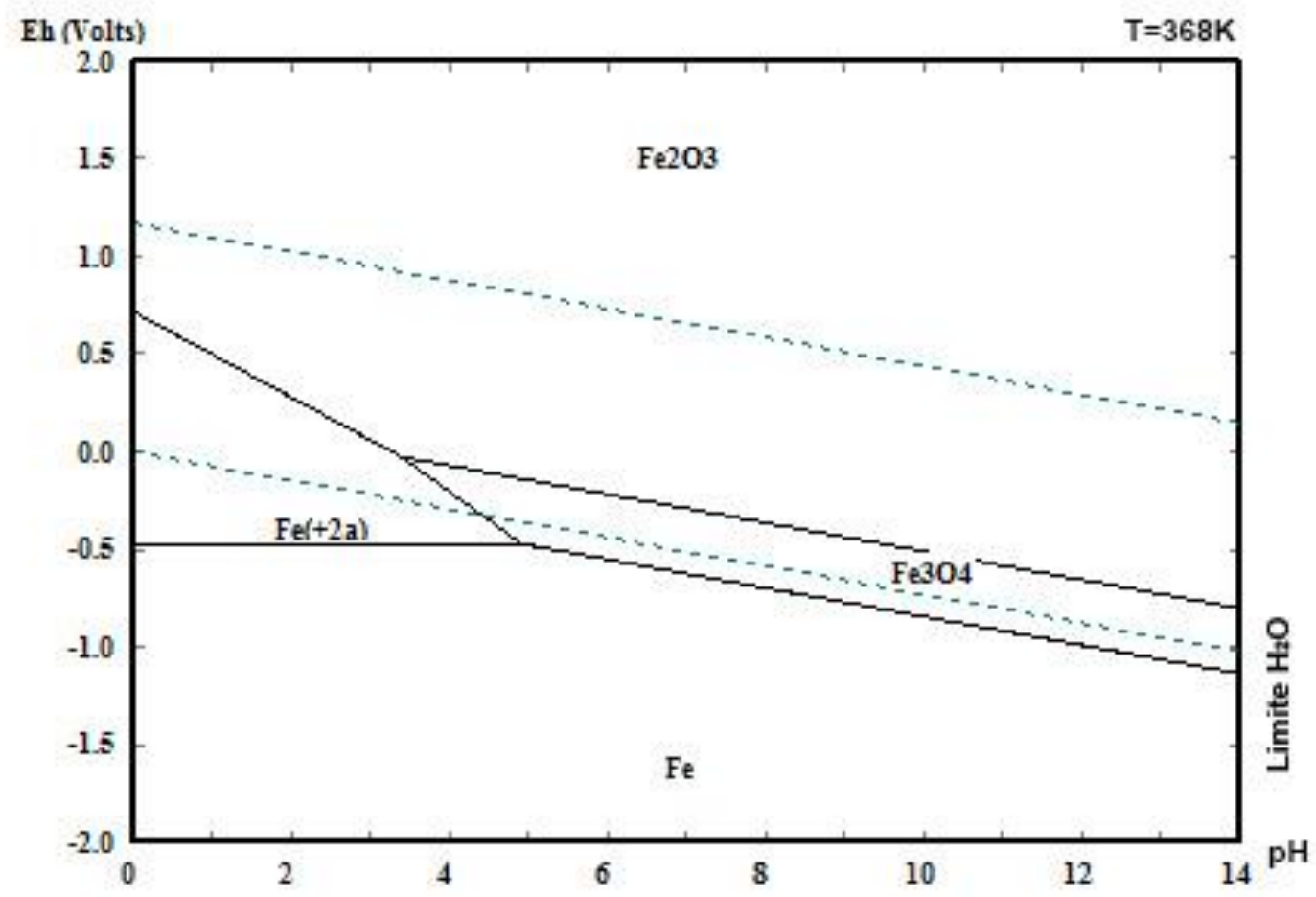

Figura 39 - Diagrama de Pourbaix para o ferro em meio aquoso para a temperatura de $95^{\circ} \mathrm{C}$. 
Nota-se, através destas figuras, que o comportamento do ferro e o campo de solubilidade pouco se alteram no intervalo de temperatura dos ensaios realizados e que, portanto, a análise dos diagramas mostra praticamente o mesmo comportamento nas dadas temperaturas.

Considerando o valor de $\mathrm{pH}$ iniciais das soluções $1 \mathrm{~mol} / \mathrm{L}$ e $2 \mathrm{~mol} / \mathrm{L}$ valendo respectivamente -0,3010 e -0,6021, portanto próximos de zero, tem-se que o ferro se encontra no campo de dissolução na forma $\mathrm{Fe}^{2+}$, uma vez que o aumento de temperatura provoca a redução dos campos das espécies solúveis catiônicas; ou seja, o mesmo efeito ocorre tanto para o íon ferroso quanto para o férrico. Todavia, o campo do íon férrico praticamente desaparece no intervalo estudado.

Assim, conclui-se que nas condições dos ensaios realizados $(\mathrm{pH}$ próximo de zero e potencial Eh entre -0,5V e 0,5V) o ferro encontrar-se-á dissolvido na forma $\mathrm{Fe}^{2+}$.

\subsection{ANÁLISE DA CINÉTICA DA REAÇÃO DE LIXIVIAÇÃO}

O estudo cinético das reações de lixiviação foi aplicado para o elemento ferro, objeto deste estudo.

Os cálculos foram feitos a partir dos dados experimentais dos ensaios de lixiviação do ferro às temperaturas de $75^{\circ} \mathrm{C}, 85^{\circ} \mathrm{C}$ e $95^{\circ} \mathrm{C}$, com ácido sulfúrico nas concentrações de $1 \mathrm{~mol} / \mathrm{L}$ e $2 \mathrm{~mol} / \mathrm{L}$.

Foi aplicado o Método do Tempo Reduzido para identificar a expressão que melhor representa o mecanismo de controle da cinética da reação de lixiviação.

Foram então aplicados os valores de extração de ferro de cada ensaio às equações lineares dos mecanismos controladores das reações químicas de lixiviação apresentados no item 4.5.2.

Os resultados do tratamento dos dados do ensaio com ácido sulfúrico $1 \mathrm{~mol} / \mathrm{L}$ são apresentados na Figura 40. 


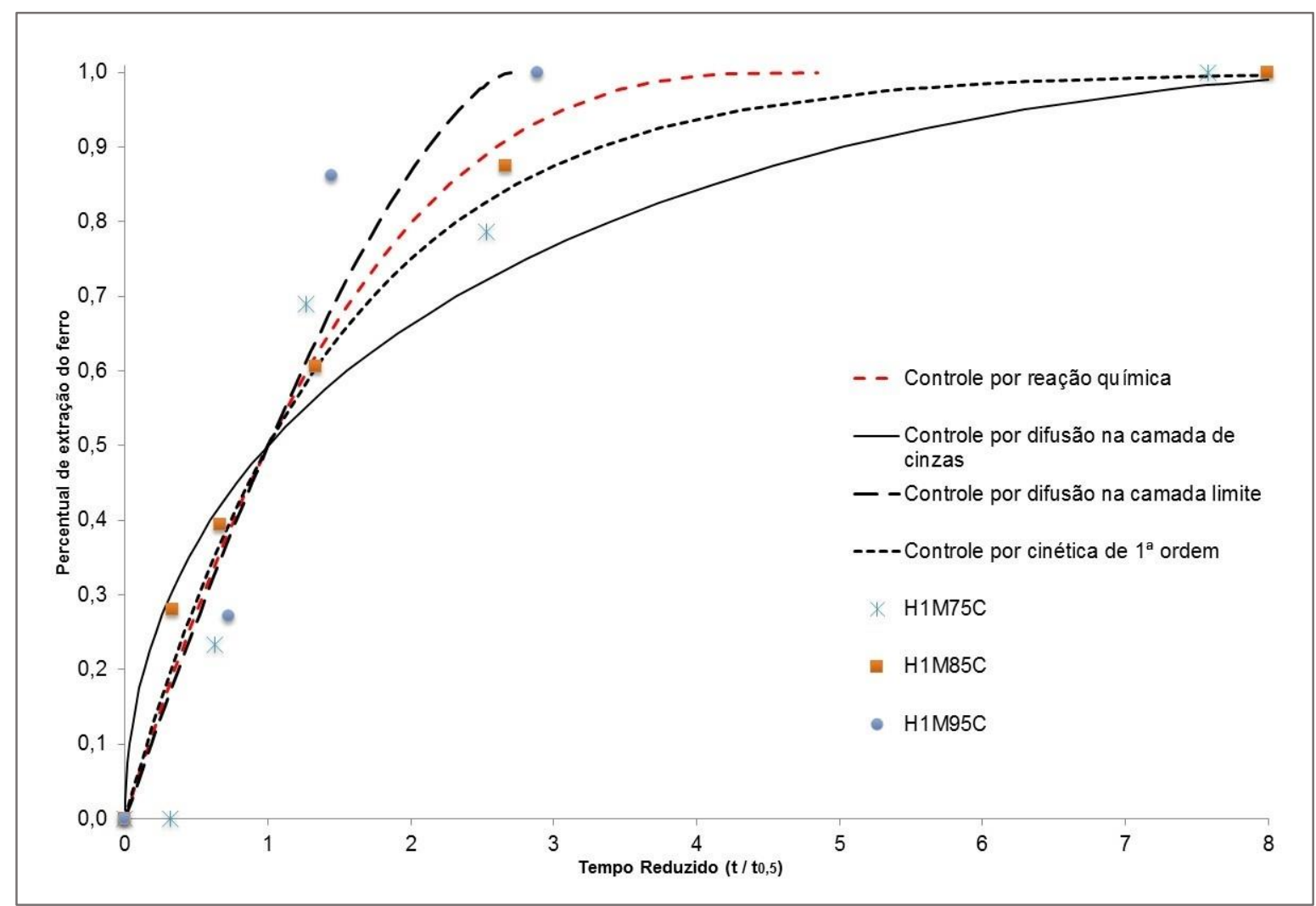

Figura 40 - Resultados das aplicações do Método do Tempo Reduzido para os valores de extração do ferro dos ensaios realizados com ácido sulfúrico $1 \mathrm{~mol} / \mathrm{L}$, objetivando a identificação do mecanismo controlador da cinética das reações de lixiviação.

A Figura 40 permitiu comparar os valores de extração dos três ensaios realizados (com ácido sulfúrico $1 \mathrm{~mol} / \mathrm{L}$ ) com as curvas teóricas dos mecanismos de controle da reação de lixiviação do ferro.

Observou-se que houve uma tendência dos resultados experimentais de seguirem o comportamento tanto da curva que representa o mecanismo de controle da cinética da reação por reação química quanto da curva que representa o controle por difusão na camada limite.

Desta forma, como não ficou clara a definição do mecanismo de controle, foram calculadas as somatórias dos quadrados das diferenças (SQD) para cada ensaio como ferramenta para auxiliar na determinação dos mecanismos de controle cinético destas reações.

A SQD foi calculada a partir do quadrado da distância de todos os pontos experimentais até as curvas teóricas dos mecanismos de controle cinético. Os resultados indicaram a aderência dos pontos a uma determinada curva, e são apresentados na Tabela 16 para cada mecanismo de controle cinético e para os três 
ensaios de lixiviação com ácido $1 \mathrm{~mol} / \mathrm{L}$ realizados; quanto menor o valor de SQD, maior a aderência à curva.

Tabela 16 - Resultados dos cálculos da somatória dos quadrados das diferenças para determinação do mecanismo de controle cinético da reação de lixiviação nos ensaios H1M75C, H1M85C e H1M95C.

\begin{tabular}{rccc}
\hline Mecanismo de controle & H1M75C & H1M85C & H1M95C \\
\hline Reação química & 0,06 & 0,01 & 0,06 \\
Difusão pela camada de cinzas & 0,14 & 0,02 & 0,16 \\
Difusão pela camada limite & 0,08 & 0,03 & 0,04 \\
Cinética de 1ª ordem & 0,08 & 0,01 & 0,09 \\
\hline
\end{tabular}

Assim como na análise da Figura 40, os dados apresentados na Tabela 16 indicaram uma tendência de controle cinético tanto por reação química quanto por difusão pela camada limite.

Foram então calculados os valores de $\mathrm{R}^{2}$, que indicaram a aderência dos valores experimentais às curvas linearizadas dos mecanismos de controle cinético das reações, para os mecanismos de controle por reação química e por difusão pela camada limite; os resultados são apresentados na Figura 41 e na Figura 42, respectivamente.

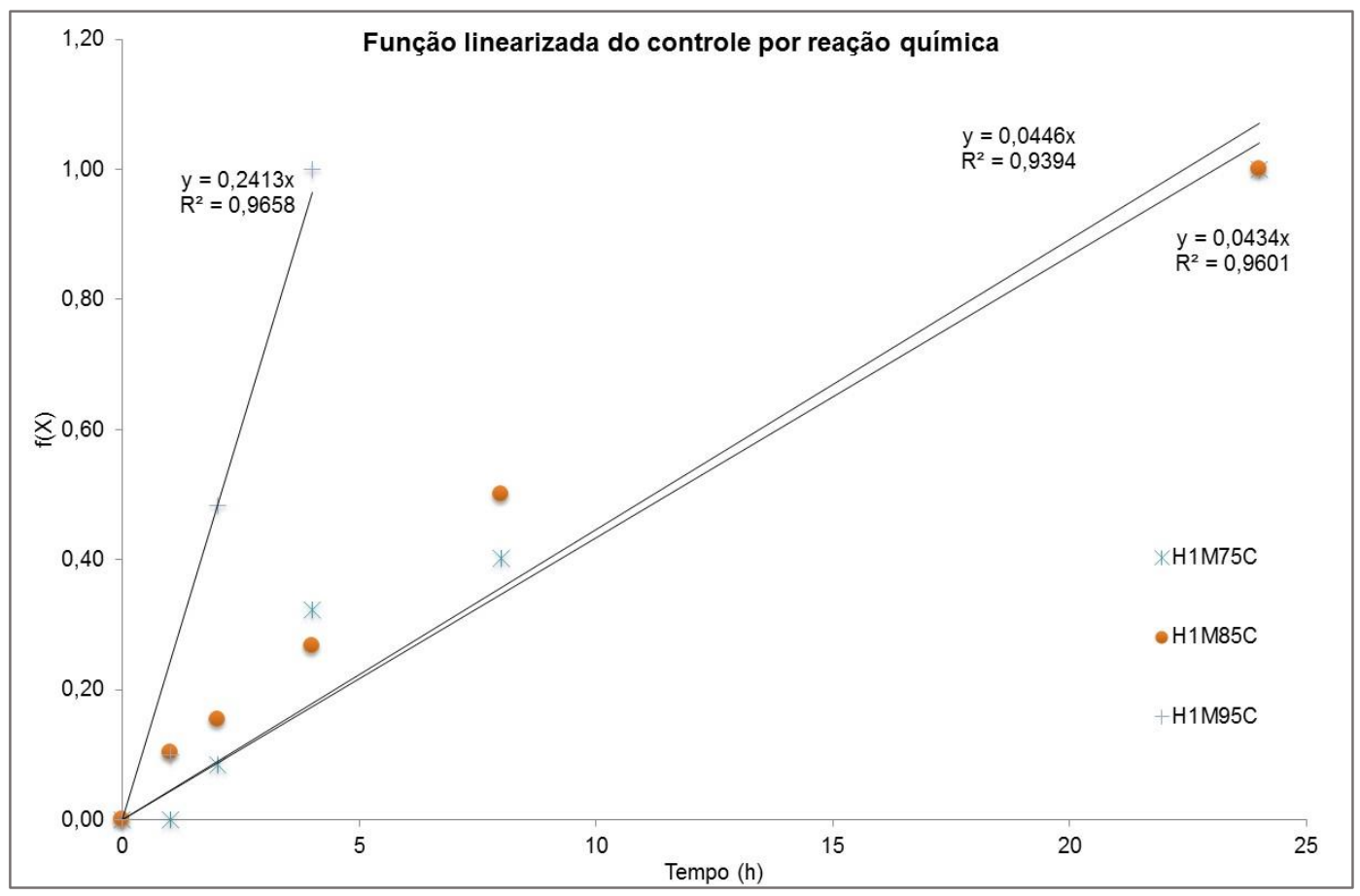

Figura 41 - Valores de $\mathbf{R}^{2}$ para os mecanismos de controle cinético por reação química para os ensaios realizados com ácido sulfúrico 1mol/L. 


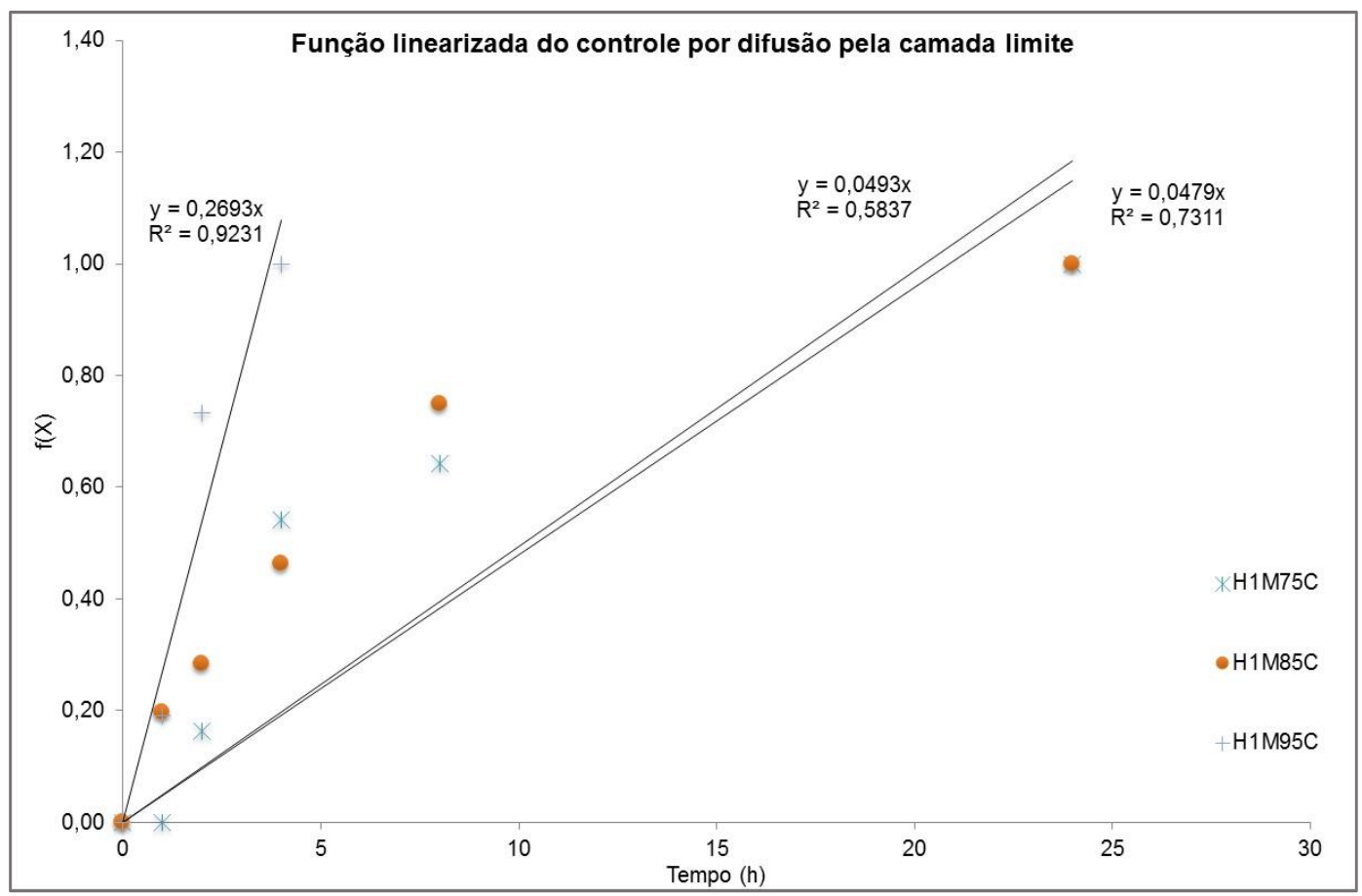

Figura 42 - Valores de $\mathbf{R}^{2}$ para os mecanismos de controle cinético por difusão pela camada limite para os ensaios realizados com ácido sulfúrico $1 \mathrm{~mol} / \mathrm{L}$.

As retas apresentadas na Figura 41 e na Figura 42 foram obtidas através do cálculo da linha de tendência dos valores experimentais aplicados às equações dos mecanismos de controle cinético.

Comparando as duas figuras, foi possível verificar que os valores de $\mathrm{R}^{2}$ para o controle por reação química foram maiores que os valores obtidos para controle por difusão, o que indicou maior adesão dos dados experimentais à expressão que representa o mecanismo de controle cinético por reação química.

Considerando o valor da constante aparente de velocidade (valor oposto do coeficiente angular da Figura 43 e da Figura 44), foi possível determinar a energia de ativação aparente do controle por reação química e do controle por difusão através das informações apresentadas na Figura 43 e na Figura 44, respectivamente. 


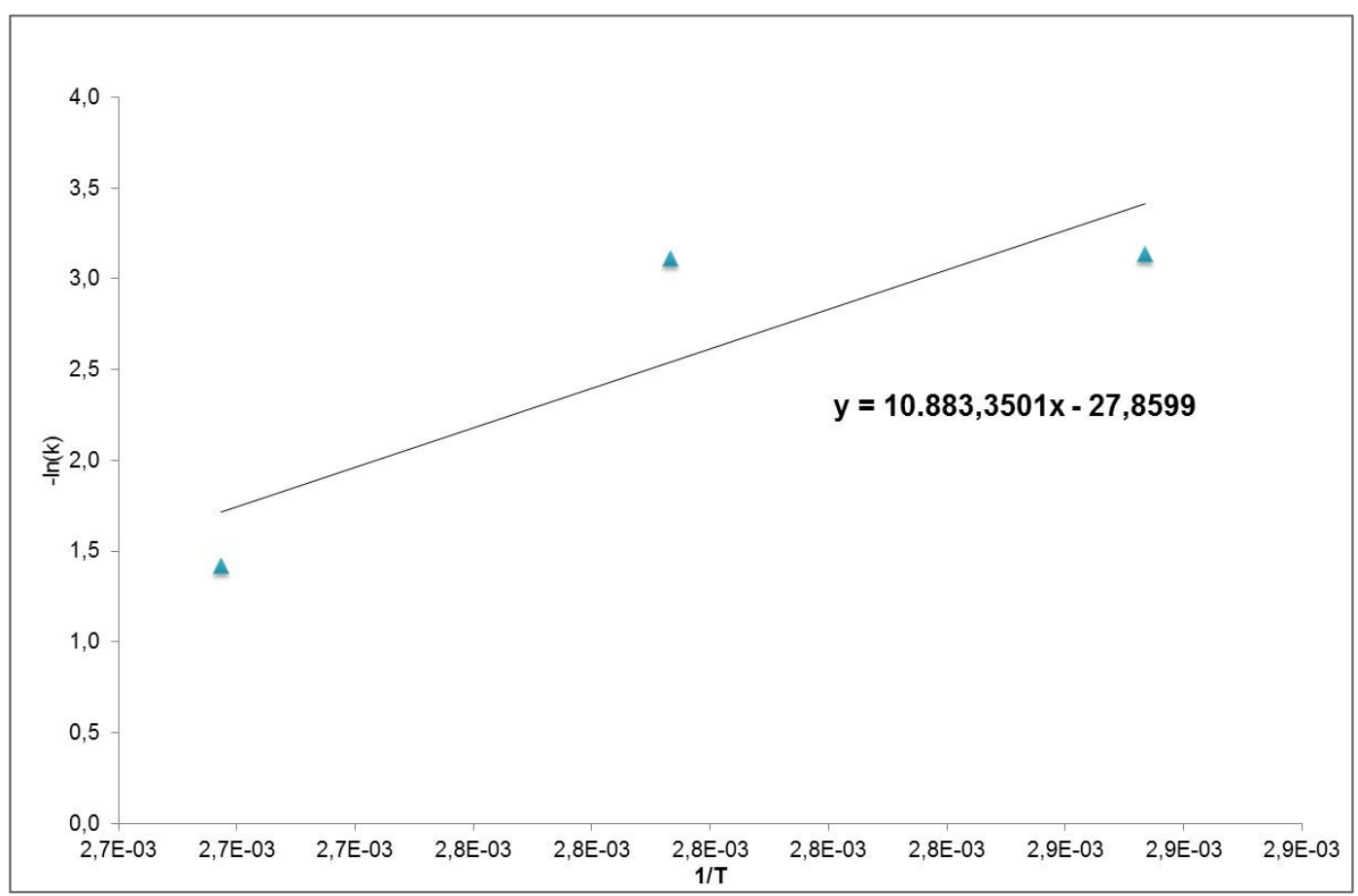

Figura 43 - Curva de -Ink pelo inverso da temperatura para determinação da energia de ativação aparente do controle por reação química dos ensaios com ácido sulfúrico $1 \mathrm{~mol} / \mathrm{L}$.

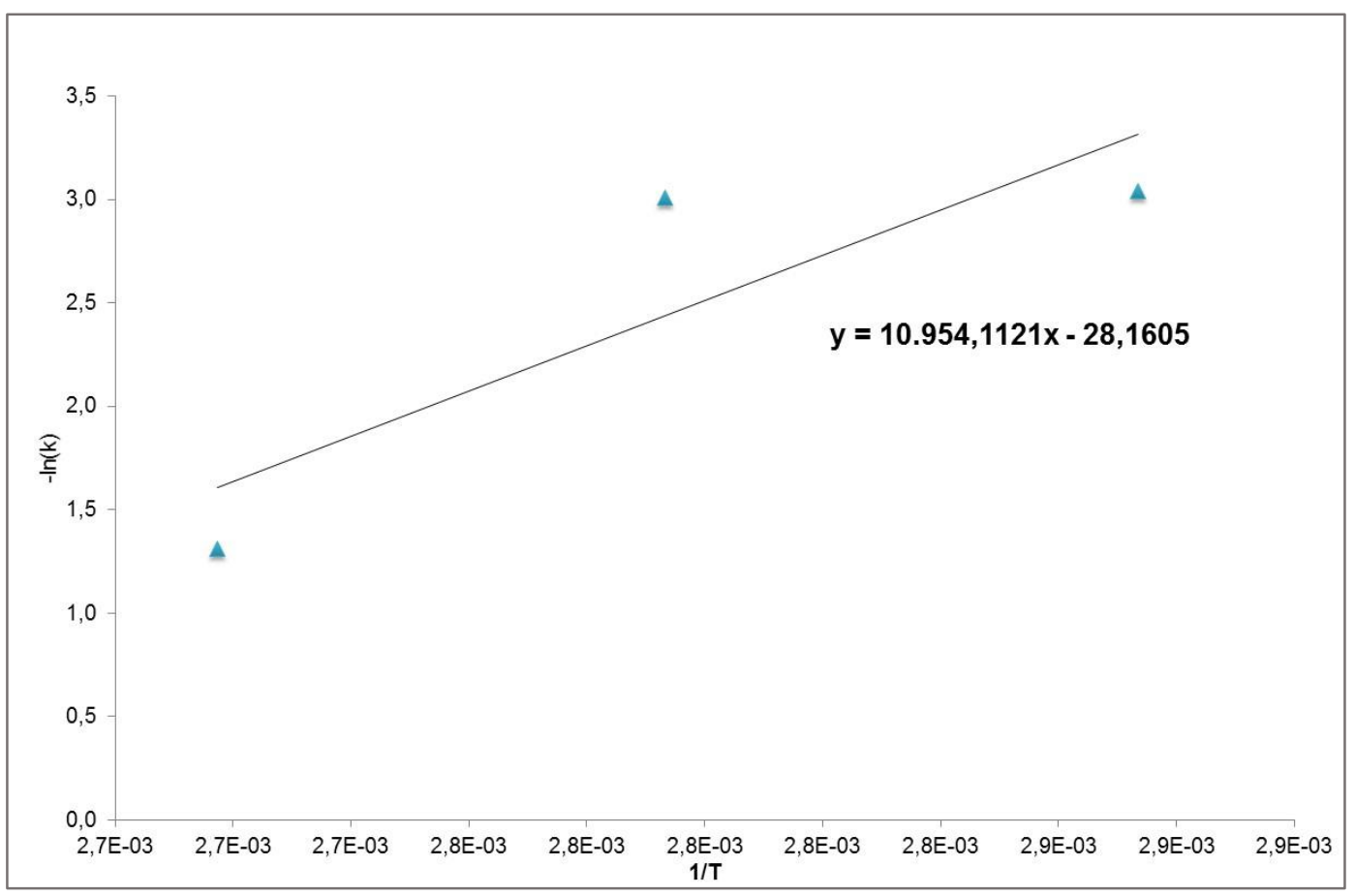

Figura 44 - Curva de -Ink pelo inverso da temperatura para determinação da energia de ativação aparente do controle por difusão pela camada limite dos ensaios com ácido sulfúrico $1 \mathrm{~mol} / \mathrm{L}$. 
A Figura 43 mostra que o valor do coeficiente angular da reta vale 10.883,4; da mesma forma, a Figura 44 mostra o valor de 10.954,1. Com estes valores, foi possível calcular o valor da energia de ativação aparente aplicando esta informação na Equação de Arrhenius (Equação 19).

Calculou-se então que 0 valor de $E_{a}$ para 0 controle por reação química equivale a $90,5 \mathrm{~kJ} / \mathrm{mol}$, e que o valor de $E_{a}$ para o controle por difusão tem o valor de $91,1 \mathrm{~kJ} / \mathrm{mol}$.

Considerando que reações controladas por difusão apresentam $E_{a}$ com valores abaixo de $40 \mathrm{~kJ} / \mathrm{mol}$ e acima disto o controle cinético acontece por reação química (Abdel-Aal, 2000), foi possível concluir que o controle cinético das lixiviações com ácido sulfúrico $1 \mathrm{~mol} / \mathrm{L}$ se dá por reação química.

Analogamente, esta mesma metodologia foi aplicada aos dados do ensaio com ácido sulfúrico $2 \mathrm{~mol} / \mathrm{L}$.

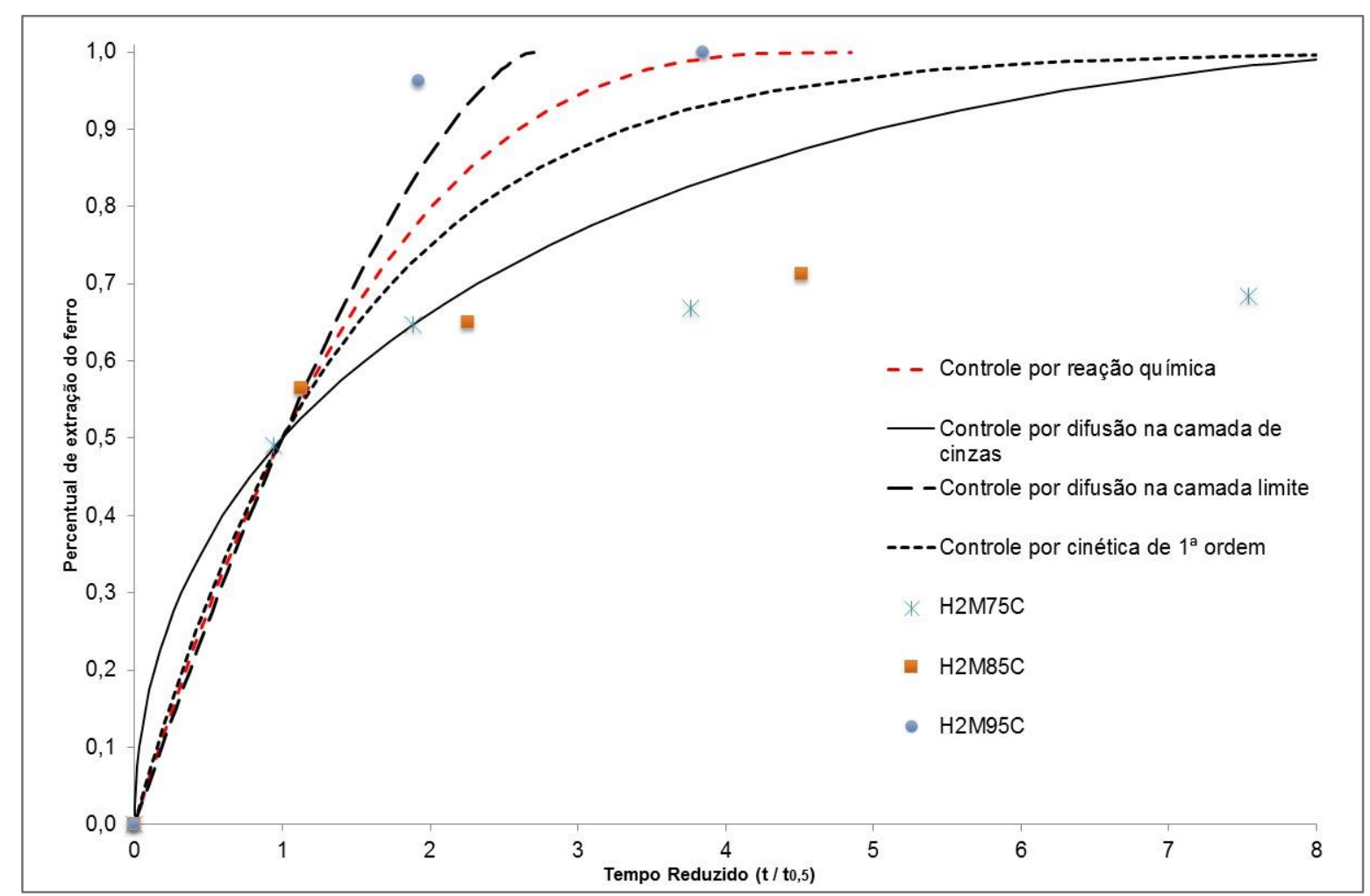

Figura 45 - Resultados do Método do Tempo Reduzido para os valores de extração de ferro dos ensaios com ácido $2 \mathrm{~mol} / \mathrm{L}$.

A Figura 45 permitiu comparar os valores de extração dos três ensaios com ácido sulfúrico $2 \mathrm{~mol} / \mathrm{L}$ com as curvas teóricas dos mecanismos controladores da reação de lixiviação do ferro. Notou-se na uma tendência dos resultados 
experimentais seguirem o comportamento da curva de controle por reação química. Entretanto, os ensaios $\mathrm{H} 2 \mathrm{M} 75 \mathrm{C}$ e H2M85C aparentemente não acompanharam nenhuma das curvas teóricas.

Na sequência, foram calculadas as SQD. Os resultados são apresentados na Tabela 17.

Tabela 17 - Resultados dos cálculos da SQD para os ensaios H2M75C, H2M85C e H2M95C.

\begin{tabular}{rccc}
\hline Mecanismo de controle & H2M75C & H2M85C & H2M95C \\
\hline Reação química & 0,33 & 0,12 & 0,03 \\
Difusão pela camada de cinzas & 0,23 & 0,03 & 0,12 \\
Difusão pela camada limite & 0,25 & 0,16 & 0,01 \\
Cinética de 1ª ordem & 0,25 & 0,08 & 0,06 \\
\hline
\end{tabular}

Apenas com os dados da Figura 45 e da Tabela 17 não foi possível afirmar qual o mecanismo de controle da cinética destas reações, pois os valores apresentados não indicam tendência clara por um determinado mecanismo.

Foram então calculados os valores de $\mathrm{R}^{2}$ para os mecanismos de controle por reação química, por difusão pela camada de cinzas e por difusão pela camada limite, respectivamente apresentados na Figura 46, na Figura 47 e na Figura 48.

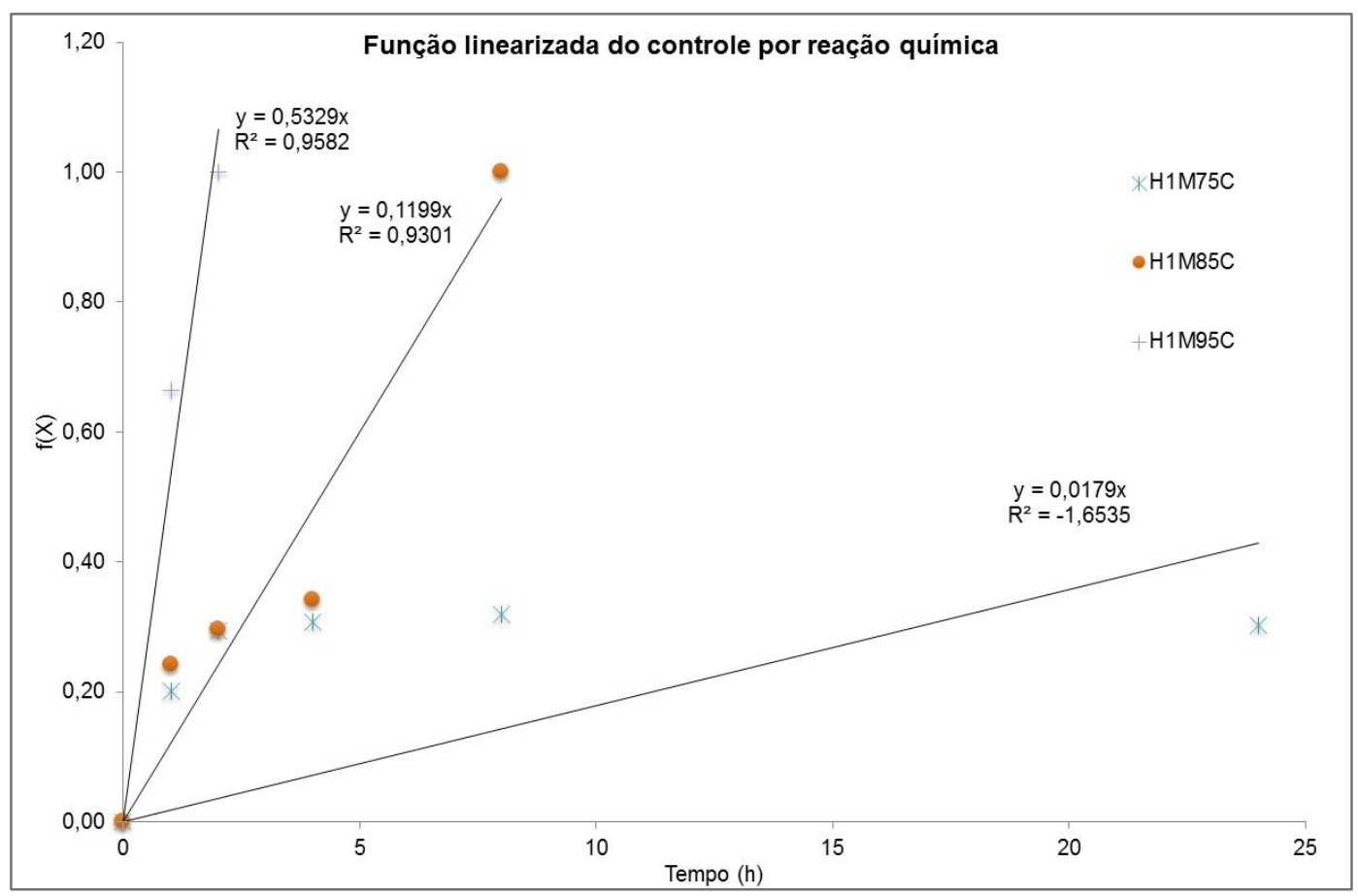

Figura 46 - Valores de $\mathbf{R}^{2}$ para o controle por reação química para os ensaios com ácido $2 \mathrm{~mol} / \mathrm{L}$. 


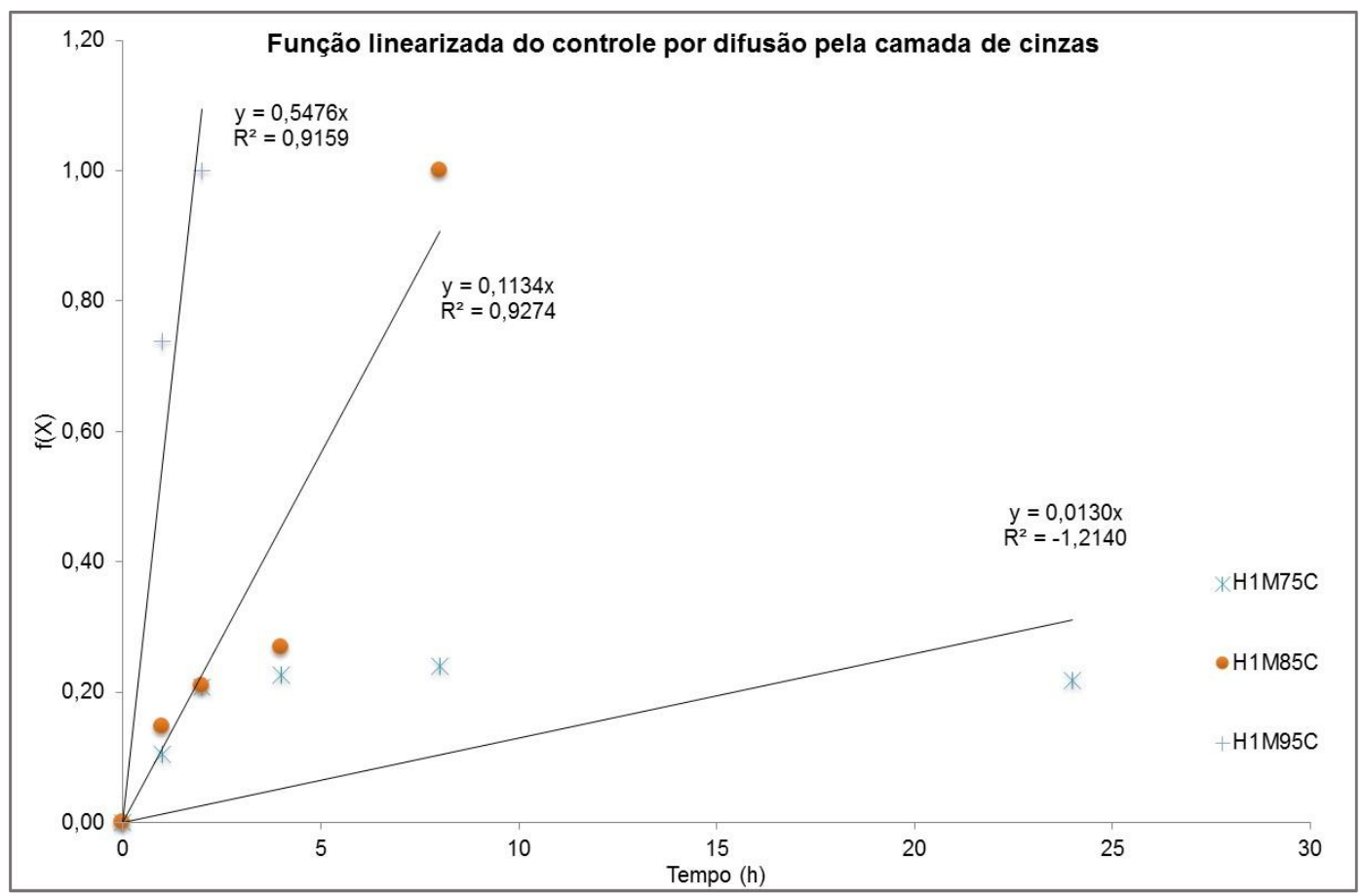

Figura 47 - Valores de $R^{2}$ para o controle por difusão pela camada de cinzas para os ensaios com ácido $2 \mathrm{~mol} / \mathrm{L}$.

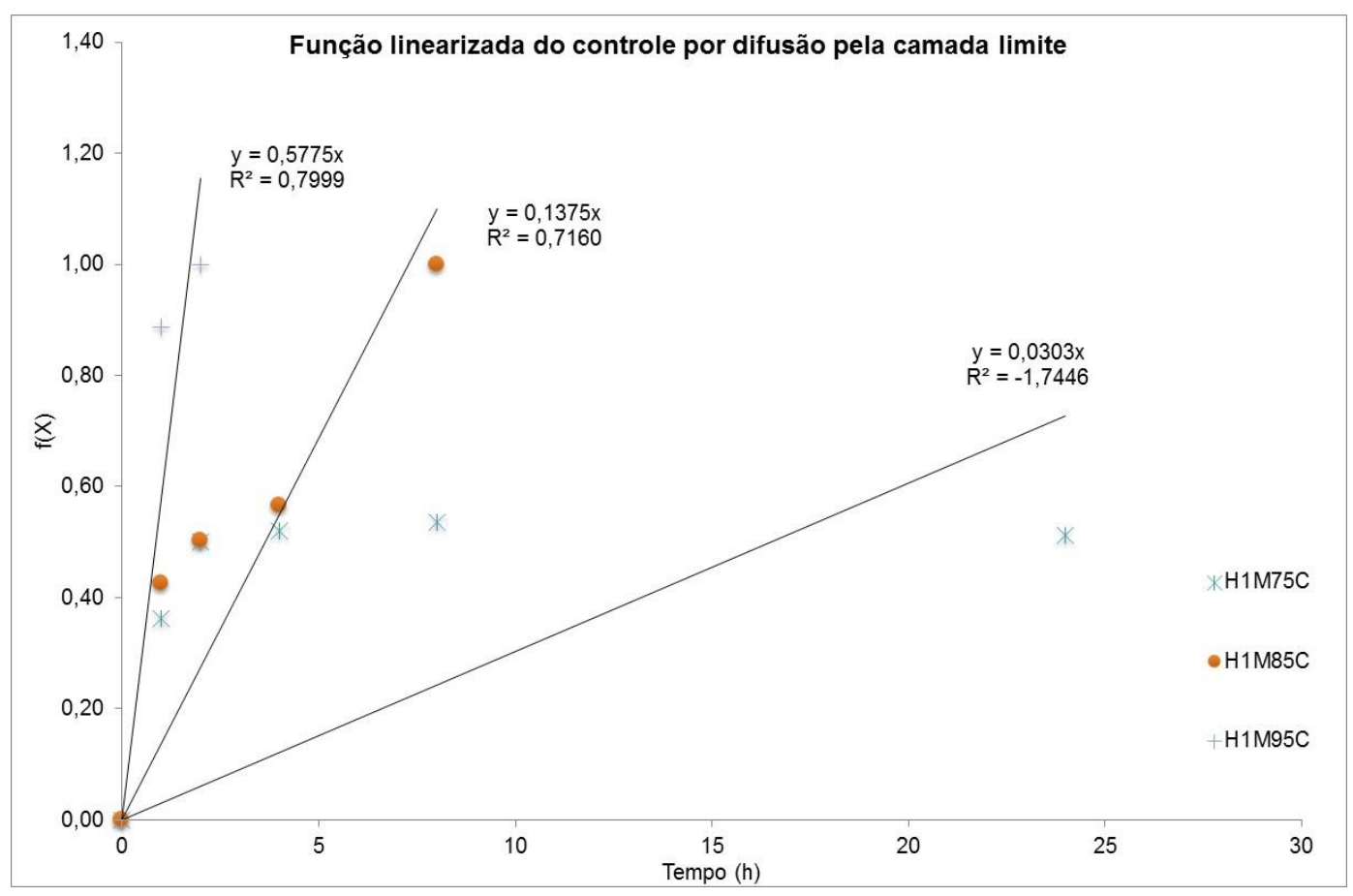

Figura 48 - Valores de $\mathbf{R}^{2}$ para o controle por difusão pela camada limite para os ensaios com ácido $2 \mathrm{~mol} / \mathrm{L}$.

Comparando as três figuras, verificou-se que os valores de $\mathrm{R}^{2}$ para o controle por reação química foram maiores que os valores obtidos para os controles por difusão na camada limite e na camada de cinzas, indicando maior adesão dos dados 
experimentais à expressão que representa o mecanismo de controle cinético por reação química.

$\mathrm{Na}$ sequência, foram determinadas as energias de ativação aparentes de cada mecanismo através da Figura 49, da Figura 50 e da Figura 51.

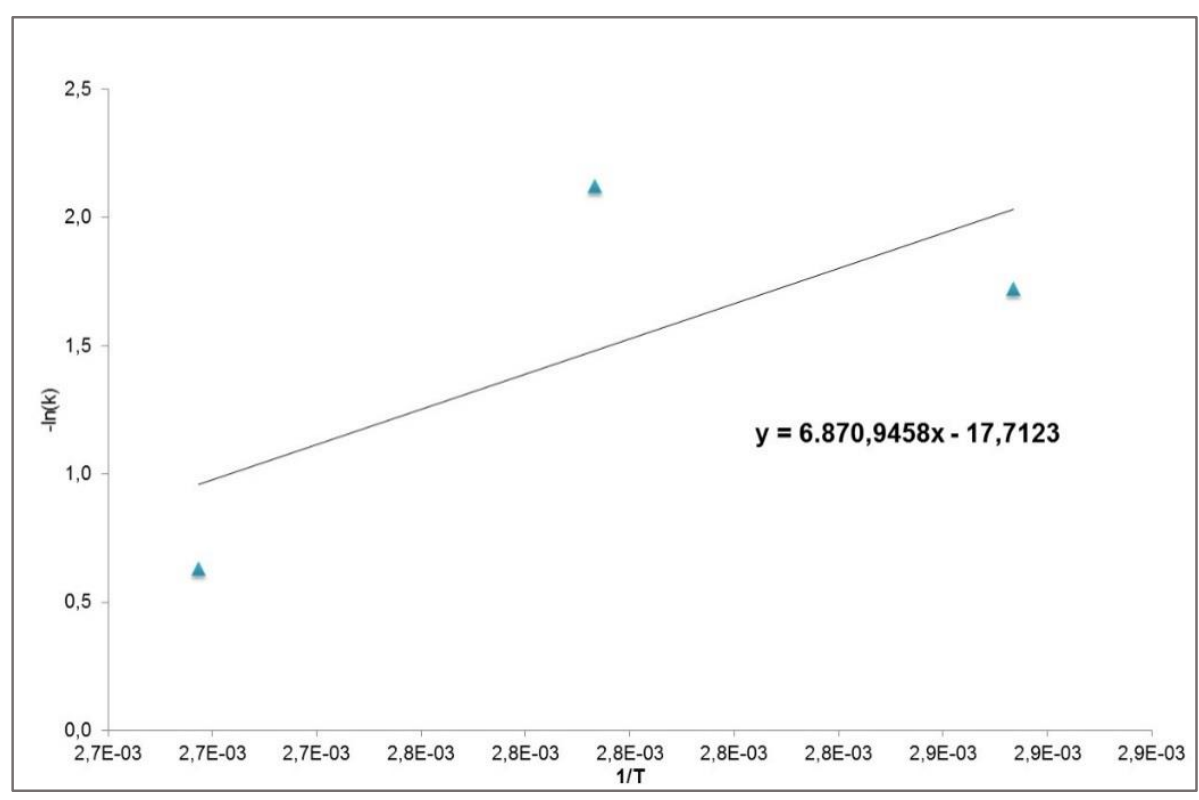

Figura 49 - Curva de -Ink pelo inverso da temperatura para determinação da energia de ativação aparente do controle por reação química dos ensaios com ácido $2 \mathrm{~mol} / \mathrm{L}$.

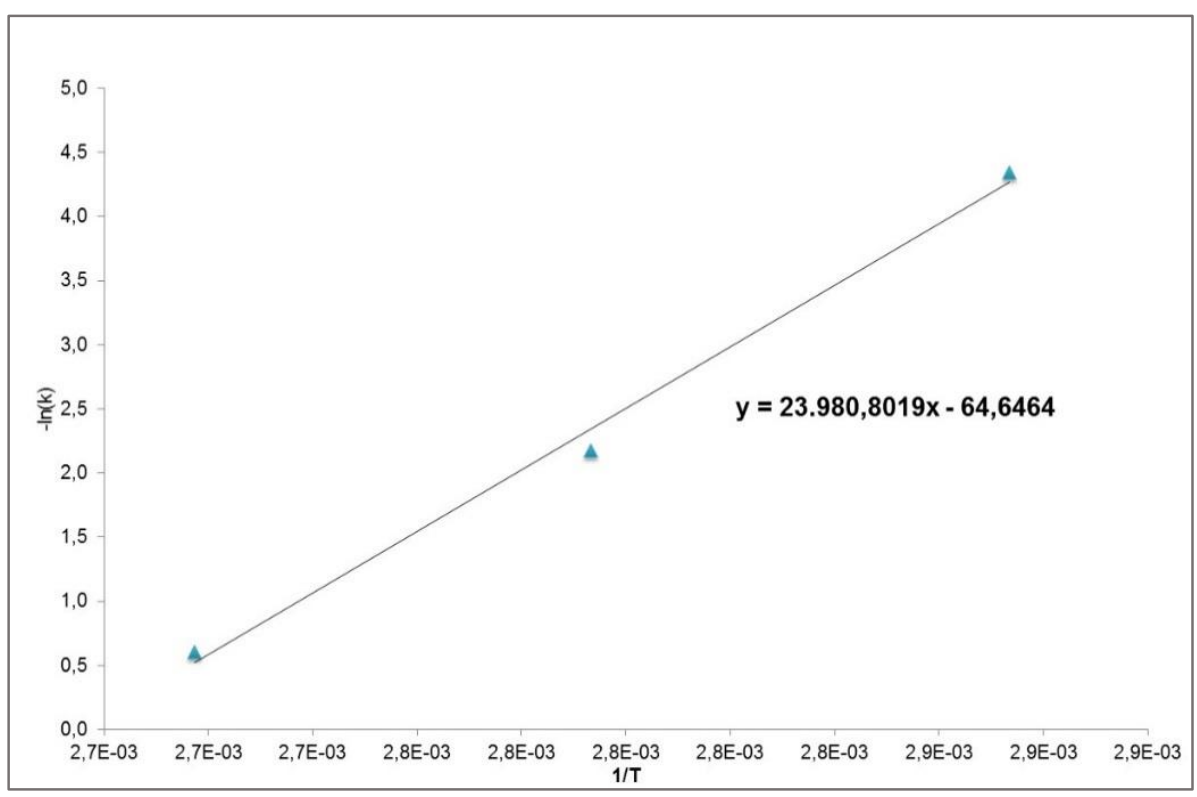

Figura 50 - Curva de -Ink pelo inverso da temperatura para determinação da energia de ativação aparente do controle por difusão pela camada de cinzas dos ensaios com ácido $2 \mathrm{~mol} / \mathrm{L}$. 


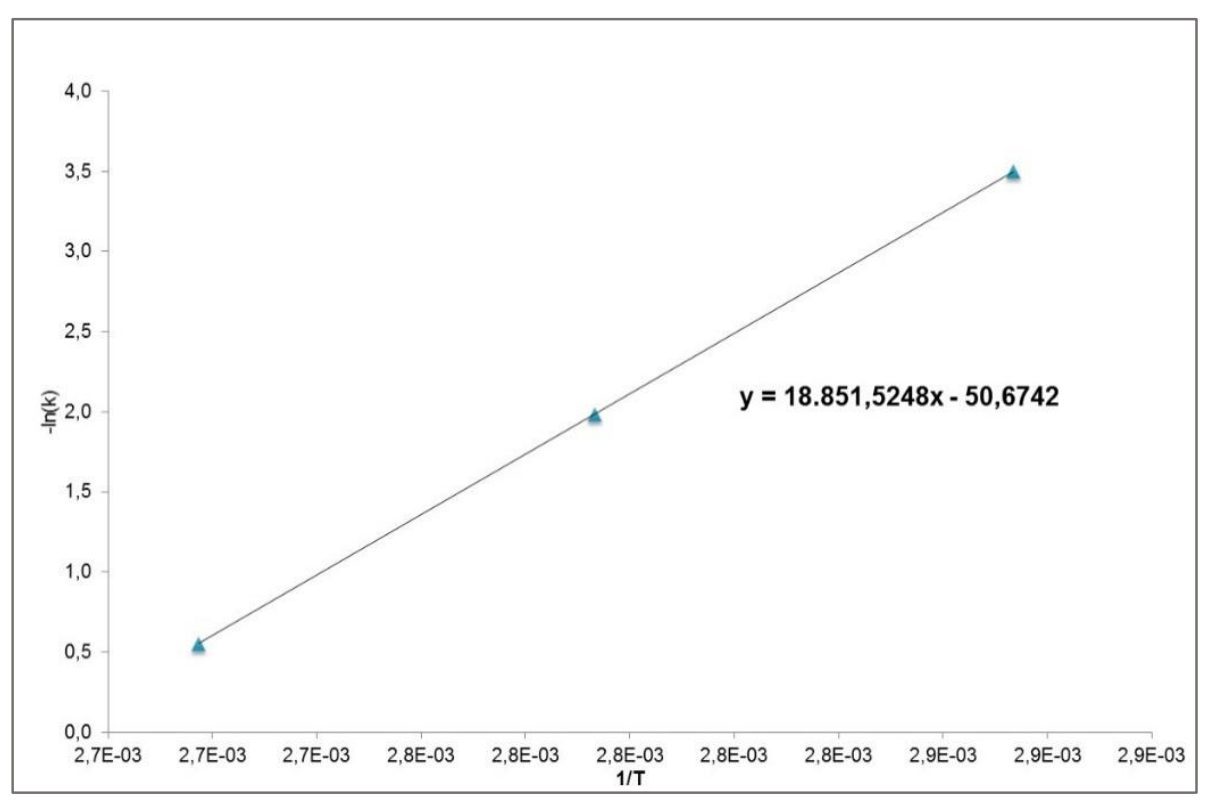

Figura 51 - Curva de -Ink pelo inverso da temperatura para determinação da energia de ativação aparente do controle por difusão pela camada limite dos ensaios com ácido $2 \mathrm{~mol} / \mathrm{L}$.

Através destas figuras, foi possível calcular o valor do coeficiente angular das retas apresentadas, que vale 6.870,9 para o controle por reação química, 23.980,8 para o controle por difusão pela camada de cinzas, e 18.851,5 para o controle por difusão pela camada limite.

Vale ressaltar que os ensaios com ácido $2 \mathrm{~mol} / \mathrm{L}$ alcançaram $100 \%$ de extração de ferro logo nas primeiras horas, e desta forma o número de pontos válidos para a análise cinética foi reduzido, resultando em incertezas nos resultados das análises das cinéticas.

Por fim, foram calculados os valores das energias de ativação aparentes: $57,1 \mathrm{~kJ} / \mathrm{mol}$ para reação química; $199,4 \mathrm{~kJ} / \mathrm{mol}$ para difusão pela camada de cinzas; e $156,7 \mathrm{~kJ} / \mathrm{mol}$ para difusão pela camada limite. Todos, portanto, acima dos $40 \mathrm{~kJ} / \mathrm{mol}$ que definem o controle por reação química.

Assim, foi possível concluir que o controle cinético das lixiviações com ácido sulfúrico $2 \mathrm{~mol} / \mathrm{L}$, assim como nos ensaios com ácido $1 \mathrm{~mol} / \mathrm{L}$, se dá por reação química. 


\section{CONCLUSÕES}

1. A lixiviação foi uma forma eficaz para a separação do ferro de placas de circuito impresso, atingindo 100\% de extração em 2 horas de processo com ácido sulfúrico à concentração de $2 \mathrm{~mol} / \mathrm{L}$ na temperatura de $95^{\circ} \mathrm{C}$.

2. O cobre praticamente não foi lixiviado nas condições dos ensaios, com índices de extração sempre menores que $0,6 \%$.

3. A cinética de lixiviação do ferro é controlada por reação química, com energia de ativação aparente de $90 \mathrm{~kJ} / \mathrm{mol}$ para os ensaios com ácido sulfúrico 1mol/L. 


\section{REFERÊNCIAS BIBLIOGRÁFICAS}

ABDEL-AAL, E. A. Kinetics of Sulfuric Acid Leaching of Low-Grade Zinc Silicate Ore. Hydrometallurgy, Elsevier, v. 55, n. 3, p. 247-254, April 2000. ISSN 10.1016/S0304-386X(00)00059-1.

ABNT. Associação Brasileira de Normas Técnicas, NBR 10.004/1987 Resíduos Sólidos, Classificação. Associação Brasileira de Normas Técnicas. Brasil. 1987.

ABNT. Associação Brasileira de Normas Técnicas, NBR 10.004/2004 Resíduos Sólidos, Classificação. Associação Brasileira de Normas Técnicas. Brasil. 2004.

ABRANTES, R. J. D. Reciclagem de placas de circuito impresso optimização da operação de processamento físico. Dissertação de Mestrado. Instituto Superior Técnico, Universidade Técnica de Lisboa. Lisboa. 2009.

ABRELPE. Panorama dos Resíduos Sólidos no Brasil 2013. Associação Brasileira de Empresas de Limpeza Pública e Resíduos Especiais. São Paulo. 2014.

AFONSO, J. C. Impactos Sócio-Ambientais do Lixo Eletrônico. V Fórum de Gestão Ambiental na Administração Pública, Instituto de Química da Universidade Federal do Rio de Janeiro, 2010.

AGÊNCIA FAPESP. Lixo recebe toneladas de ouro e prata por ano. Agência Fapesp, 06 jul. 2012. Disponível em: <http://agencia.fapesp.br/15846>. Acesso em: 30 Janeiro 2013.

AGÊNCIA PORTAL BRASIL. Economia e Emprego: Estudo sobre Logística de Resíduos Eletrônicos é Divulgado. Portal Brasil, 2014. Disponível em: <www.brasil.gov.br/economia-e-emprego/>. Acesso em: 30 Julho 2014.

AISSE, M. M.; OBLADEN, N. L.; SANTOS, A. S. Aproveitamento dos resíduos sólidos urbanos. CNPq/ITAH/IPPUC/LHISAMA-ICPr. Curitiba, p. 197. 1981.

ANDRADE, R. Caracterização e classificação de placas de circuito impresso de computadores como resíduos sólidos. Dissertação de Mestrado. Universidade Estadual de Campinas - Unicamp. Campinas. 2002. 
ANTHONY, M. T.; FLEET, D. S. Hydrometallurgy - An Environmentally Sustainable Technology? International Symposium Hydrometallurgy '94' - Institution of Mining and Metallurgy and the Society of Chemical Industry. Cambridge: Springer Netherlands. 1994. p. 13-26.

AROLD, L. F.; CORREA, M. M. J.; MORAES, V. T.; TENÓRIO, J. A. S.; ESPINOSA, D. C. R. Caracterização dos Metais Presentes na Fração Não Magnética das Placas de Circuito impresso de Computadores. Contribuição Técnica ao $69^{\circ}$ Congresso Anual da ABM - Internacional e ao $14^{\circ}$ ENEMET - Encontro Nacional de Estudantes de Engenharia Metalúrgica, de Materiais e de Minas. São Paulo. 2014.

ATKINS, P. W.; JONES, L. Chemical Principles - The Quest for Insight. 5th. ed. New York: W.H.Freeman and Company, v. 1, 2009.

BAKAS, I.; FISCHER, C.; HASELSTEINER, S.; MCKINNON, D.; MILIOS, L.; HARDING, A.; KOSMOL, J.; PLEPYS, A.; TOJO, N.; WILTS, H.; WITTMER, D. Present and Potential Future Recycling of Critical Metals in WEEE. Copenhagen Resource Institute. Copenhagen. 2014.

BAS, A. D.; DEVECI, H.; YAZICI, E. Y. Treatment of Manufacturing Scrap TV Boards by Nitric Acid Leaching. Separation and Purification Technology, Turkey, v. 130, p. 151-159, June 2014. ISSN 10.1016/j.seppur.2014.04.008.

BEHNAMFARD, A.; SALARIRAD, M. M.; VEGLIO, F. Process Development for Recovery of Copper and Precious Metals from Waste Printed Circuit Boards with Emphasize on Palladium and Gold Leaching and Precipitation. Waste Management, v. 33, n. 11, p. 2354-2363, November 2013. ISSN 10.1016/j.wasman.2013.07.017.

BIRLOAGA, I.; MICHELIS, I.; FERELLA, F.; BUZATU, M.; VEGLIÒ, F. Study on the Influence of Various Factors in the Hydrometallurgical Processing of Waste Printed Circuit Boards for Copper and Gold Recovery. Waste Management, v. 33, n. 4, p. 935-941, April 2013. ISSN 10.1016/j.wasman.2013.01.003.

BIZZO, W. A. Gestão de Resíduos e Gestão Ambiental da Indústria EletroEletrônica. Abinee Tec, Universidade Estadual de Campinas - Unicamp, p. 14, 2007.

BRASIL. Lei número 12.305, de 2 de Agosto de 2010 - Política Nacional de Resíduos Sólidos. Institui a Política Nacional de Resíduos Sólidos; altera a Lei número 9.605, de 12 de fevereiro de 1998; e dá outras providências, Brasília, 2010. 
BURKIN, A. R. Chemical Hydrometallurgy - Theory and Principles. London: Imperial College Press, 2001.

CALDAS, M. P. K.; MORAES, V. T.; SOUSA, L. M.; ESPINOSA, D. C. R.; TENÓRIO, J. A. S. Caracterização de Placas de Circuito Impresso de Computadores Visando Recuperação de Metais Preciosos por Meio de Nanopartículas. 69 Congresso Anual da ABM - Gestão de Meio Ambiente e Recuperação e Tratamento de Rejeitos, São Paulo, 2014.

CALDAS, M. P. K.; MORAES, V. T.; SILVAS, F. P. C.; ESPINOSA, D. C. R.; TENÓRIO, J. A. S. Characterization of Computers Printed Circuit Boards in Order to Recover Precious Metal by Nanoparticles. Industrial and Hazardous Waste Management. Crete: 4th International Conference. 2014.

CALDAS, M. P. K.; MORAES, V. T.; ESPINOSA, D. C. R.; TENÓRIO, J. A. S. Estudo de Rota Hidrometalúrgica Visando a Extração de Prata Estanho de Solda Presente em PCI. Contribuição Técnica ao 69ํㅡㄹ Congresso Anual da ABM Internacional e ao 14을 ENEMET - Encontro Nacional de Estudantes de Engenharia Metalúrgica, de Materiais e de Minas. São Paulo: ABM. 2014.

CALDAS, M. P. K.; MORAES, V. T.; JUNCA, E.; TENÓRIO, J. A. S.; ESPINOSA, D. C. R. Reciclagem de Placas de Circuito Impresso Visando Recuperação de Prata: Estudo de uma Rota Hidrometalúrgica. Tecnologia em Metalurgia, Materiais e Mineração TMMM. ABM, São Paulo, v. 12, n. 2, p. 102-108, Abril/Junho 2015. ISSN 10.4322/2176-1523.0850.

ÇAMCI, L.; AYDIN, S.; ARSLAN, C. Reduction of Iron Oxides in Solid Wastes Generated by Steelworks. Turkish Journal of Engineering \& Environmental Sciences, Istanbul, n. 26, p. 37-44, 2002.

CAMPOS, H. K. T. Renda e Evolução da Geração per Capita de Resíduos Sólidos no Brasil. Engenharia Sanitária Ambiental, v. 17, n. 2, p. 171-180, 2012.

CAMPOS, L. F. L.; OLIVEIRA, M. D. Gestão de resíduo tecnológico gerado pela tecnologia da informação. Universidade Federal de Juiz de Fora. Minas Gerais. 2009.

CARRISSO, R. C. C.; CORREIRA, J. C. G. Classificação e Peneiramento. Em: LUZ, A. B. D.; SAMPAIO, J. A.; FRANÇA, S. C. A. Tratamento de Minérios. 4ª ed. Rio de Janeiro: Centro de Tecnologia Mineral - CETEM, v. 1, 2004. Cap. 5, p. 197238. 
CASTRO, L. A.; MARTINS, A. H. Recovery of Tin and Copper by Recycling of Printed Circuit Boards from Obsolete Computers. Brazilian Journal of Chemical Engineering, Brazil, v. 26, n. 04, p. 649-657, December 2009.

CECON, K. A Tradução Química de Experimentos Alquímicos Envolvendo Água Régia em Robert Boyle. Scientiae Studia, São Paulo, v. 10, n. 4, p. 711-732, 2012. ISSN 1678-3166.

CEDIR. Lixo Eletrônico: O Que Fazer Com Ele. Centro de Descarte e Reuso de Resíduos de Informática - CEDIR, 2011. Disponível em: <http://www5.usp.br/2549/lixo-eletronico-o-que-fazer-com-ele/>. Acesso em: 29 Maio 2015.

CEMPRE. Microcenários Setoriais sobre Reciclagem no Brasil. Compromisso Empresarial para a Reciclagem. São Paulo. 2004.

CHANCEREL, P.; ROTTER, S. Recycling-oriented characterization of small waste electrical and electronic equipment. Waste Management, v. 29, n. 8, p. 23362352, 2009.

CIMINELLI, V. S. T. Tendência Biológicas Brasil 2015. Geociências e Tecnologia Mineral, Capítulo 4: Hidrometalurgia, p. 157-174, 2007.

COLMER, A. R.; TEMPLE, K. L.; HINKLE, M. E. An Iron-Oxidizing Bacterium from the Acid Drainage of Some Bituminous Coal Mines. Journal of Bacteriology, Morgantown, West Virginia, v. 59, n. 3, p. 317-328, March 1950.

CONAMA. Conselho Nacional do Meio Ambiente. Ministério do Meio Ambiente. Disponível em: <http://www.mma.gov.br/port/conama/>. Acesso em: 22 Março 2014.

COOMBS JR., C. F. Printed Circuits Handbook. 6th. ed. New York: McGrawHill Handbooks, 2008.

CORREA, M. M. J. Separação e Purificação de Metais Presentes em Placas de Circuito Impresso de Computadores Descartados Utilizando-se Extração por Solventes. Dissertação de Mestrado. Escola Politécnica da Universidade de São Paulo - EPUSP. São Paulo. 2015.

CORREA, M. M. J.; AROLD, L. F.; MORAES, V. T.; TENÓRIO, J. A. S.; ESPINOSA, D. C. R. Characterization of Video Printed Circuit Boards from Computers. Industrial and Hazardous Waste Management. Crete: 4th International Conference. 2014. 
CORREA, M. M. J.; TENÓRIO, J. A. S.; ESPINOSA, D. C. R. Processamento Mecânico das Placas Mães de Computadores. 69ํㅡㄹ Congresso Anual da ABM Internacional \& 14ํㅡㄹ ENEMET - Encontro Nacional de Estudantes de Engenharia Metalúrgica, de Materiais e de Minas. São Paulo: Associação Brasileira de Metalurgia e Materiais. 2014.

CUI, J.; FORSSBERG, E. Mechanical Recycling of Waste Electric and Electronic Equipment: A Review. Journal of Hazardous Materials, v. 99, n. 3, p. 243263, 2003.

CUI, J.; ZHANG, L. Metallurgical Recovery of Metals from Electronic Waste: A Review. Journal of Hazardous Materials, v. 158, p. 228-256, February 2008.

DALRYMPLE, I.; WRIGHT, N.; KELLNER, R.; BAINS, N.; GERAGHTY, K.; GOOSEY, M.; LIGHFOOT, L. An Integrated Approach to Electronic Waste (WEEE) Recycling. Circuit World, UK, v. 33, n. 2, p. 52-58, 2007.

DAS, A.; VIDYADHAR, A.; MEHROTRA, S. P. A Novel Flowsheet for the Recovery of Metal Values from Waste Printed Circuit Boards. Resources, Conservation and Recycling, v. 53, n. 8, p. 464-469, June 2009.

DEVESA, F.; LÓPES, J.; SAMPER, M. D.; PARRES, F. Análisis del reciclado conjunto de ABS y HIPS obtenidos a partir de residuos eléctricos y electrónicos. I Simposio Iberoamericano de Ingeniería de Residuos, Castellón, España, Julio 2008.

DIAS, S. C.; BRASILINO, M. D. G. A. Aulas Práticas de Química Inorgânica I. Centro de Ciências Exatas e da Natureza. Universidade Federal da Paraíba. João Pessoa. 2010.

DRECHSEL, C. Flexible mechanical approach to recycling WEEE. Recycling International, Arnhem, The Netherlands, 2006.

DTI GLOBAL WATCH MISSION. Waste electrical and electronic equipment (WEEE): innovating novel recovery and recycling technologies in Japan. Global Watch Mission Report, United Kingdom, September 2005.

DUBY, P. The Thermodynamic Properties of Aqueous Inorganic Copper Systems. National Standard Reference Data System. Fort Belvoir, p. 132. 1977. (ADD095417). 
DURAN, J. F. O. Método para Determinar a Energia Descartada por Tratamento Inadequado de uma Família de Produtos Devido à Obsolescência Programada. Dissertação de Mestrado. Universidade Federal de Santa Catarina. Florianópolis, p. 115. 2014.

DUTRA, R. Beneficiamento de Minerais Industriais. II Encontro de Engenharia e Tecnologia dos Campos Gerais. Ponta Grossa, Paraná: AEAPG. 2006.

ELCO. Products: Multilayer PCB's. Elco PCB - Elco Group, 2015. Disponível em: <www.elcopcb.com>. Acesso em: 12 June 2015.

ESPINOSA, D. C. R.; TENÓRIO, J. A. S. O Estado-da-Arte em Reciclagem de Pilhas e Baterias. 4ํㅡㄹ Encontro Técnico Anual da Associação dos Engenheiros da CETESB. São Paulo: ASEC. 2003.

FADIGAS, J. Apostila de Química Analítica Quantitativa. Centro de Educação Tecnológica do Estado da Bahia - Unidade de Camaçari. Camaçari. 2013.

FECOMERCIOSP. Resíduos Sólidos: o que o empresário do comércio e serviços precisa saber. Federação do Comércio de Bens, Serviços e Turismo do Estado de São Paulo. São Paulo. 2011.

FECOMERCIOSP. Resíduos Sólidos e Logística Reversa: O Que 0 Empresário do Comércio e Serviços Precisa Saber e Fazer. Federação do Comércio de Bens, Serviços e Turismo do Estado de São Paulo. São Paulo. 2014.

FERREIRA JUNIOR, O. L. Processo de Separação de Materiais Metálicos e Não Metálicos na Reciclagem de Resíduos de Placas de Circuito Impresso de Microcomputadores. Dissertação de Mestrado. Instituto de Pesquisas Energéticas e Nucleares - IPEN. Universidade de São Paulo. São Paulo. 2013.

GERBASE, A. E.; OLIVEIRA, C. R. D. Reciclagem do Lixo de Informática: Uma Oportunidade para a Química. Química Nova, v. 35, n. 7, p. 1486-1492, 2012. GILBERT, S. R.; POUNDS, C. O.; ICE, R. R. Comparative Economics of Bacterial Oxidation and Roasting as a Pretreatment for Gold Recovery from an Auriferous Pyrite Concentrate. CIM Bulletin, n. 81, p. 89-94, 1988.

GONÇALVES, C. K. Pirólise e Combustão de Resíduos Plásticos. Dissertação de Mestrado. Escola Politécnica da Universidade de São Paulo - EPUSP. São Paulo. 2007. 
GOOSEY, M.; KELLNER, R. Recycling Technologies for the Treatment of End of Life Printed Circuit Boards (PCBs). Circuit World, UK, v. 29, n. 3, p. 33-37, 2003. ISSN 0305-6120.

GRAMATYKA, P.; NOWOSIELSKI, R.; SAKIEWICZ, P. Recycling of Waste Electrical and Electronic Equipment. Journal of Achievements in Materials and Manufacturing Engineering, Gliwice, Poland, v. 20, n. 1-2, p. 535-538, JanuaryFebruary 2007.

GUPTA, C. K. Pyrometallurgy. Em: GUPTA, C. K. Chemical Metallurgy: Principles and Practice. Weinheim: WILEY-VCH Verlag GmbH \& Co. KGaA, 2003. p. 343-458.

HAVLIK, T.; ORAC, D.; PETRANIKOVA, M.; MISKUFOVA, A.; FUKURUGYA, F.; TAKACOVA, Z. Extraction of copper, zinc, nickel and cobalt in acid oxidative leaching of chalcopyrite at the presence of deep-sea manganese nodules as oxidant. Hydrometallurgy 77, p. 51-59, 2005.

HAVLIK, T.; LAUBERTOVA, M.; MISKUFOVA, A.; KONDAS, J.; VRANKA, F. Leaching of Copper and Tin from Used Printed Circuit Boards After Thermal Treatment. Journal of Hazardous Materials, Elsevier B.V., v. 183, n. 1-3, p. 866-873, November 2010. ISSN 10.1016/j.jhazmat.2010.07.107.

HAYES, P. C. Process Selection in Extractive Metallurgy. Brisbane, Australia: Hayes Publishing, v. 31, 1985.

HILL JR., C. G.; ROOT, T. W. Introduction to Chemical Engineering Kinetics \& Reactor Design. 2nd. ed. Hoboken: John Wiley \& Sons Inc., 2014.

HISCHIER, R.; WAGER, P.; GAUGLHOFER, J. Does WEEE Recycling Make Sense from an Environmental Perspective? Environment Impact Assessment Review: The Environmental Impacts of the Swiss Take-Back and Recycling Systems for Waste Electrical and Electronic Equipment (WEEE), St. Gallen, Switzerland, 2005.

HOFFMANN, J. E. Recovery of Precious Metals from Electronic Scrap. Journal of Metals, The Minerals, Metals \& Materials Society - TMS. Warrendale, v. 44, n. 7, p. 43-48, July 1992.

HUTCHINS, S. R.; DAVIDSON, M. S.; BRIERLEY, J. A.; BRIERLEY, C. L. Microorganisms in the Reclamation of Metals. Annual Review of Microbiology. Golden, Colorado: Advanced Mineral Technologies Inc. 1986. p. 311-336. 
IBGE. Artigos e Apresentações - Censo Demográfico 2010. Instituto Brasileiro de Geografia e Estatística, 2010. Disponível em: <www.ibge.com.br/>. Acesso em: 12 Maio 2015.

IGLECIAS, P. Logística Reversa e Reciclagem de Resíduos Pós-Consumo. Seminário Reciclagem e Valorização de Resíduos Sólidos. Grupo de Estudos Aplicados ao Meio Ambiente - GEAMA-USP. São Paulo. 2014.

IPEA. Relatório de Pesquisa: Diagnóstico dos Resíduos Sólidos Urbanos. Instituto de Pesquisa Econômica Aplicada. Brasília. 2012.

JACKSON, E. Hydrometallurgical Extraction and Reclamation. New York: Ellis Horwood Ltd., 1986.

JHA, M. K.; KUMARI, A.; CHOUBEY, P. K,; LEE, J. C.; KUMAR, V.; JEONG, J. Leaching of Lead from Solder Material of Waste Printed Circuit Boards (PCBs). Hydrometallurgy, Elsevier, v. 121-124, p. 28-34, June 2012. ISSN 10.1016/j.hydromet.2012.04.010.

KASPER, A. C. Caracterização e reciclagem de materiais presentes em sucatas de telefones celulares. Dissertação de Mestrado. Programa de pósgraduação em Engenharia de Minas, Metalúrgica e de Materiais PPGE3M. Universidade Federal do Rio Grande do Sul - UFGRS. Porto Alegre. 2011.

KASPER, A. C.; BERSELLI, G. B. T.; FREITAS, B. D.; TENÓRIO, J. A. S.; BERNARDES, A. M.; VEIT, H. M. Printed wiring boards for mobile phones: characterization and recycling of copper. Waste Management, v. 31, 2011.

KHETRIWAL, D. S.; WIDMER, R.; KUEHR, R.; HUISMAN, J. One WEEE, Many Species: Lessons from the European Experience. Waste Management \& Research, v. 29, n. 9, p. 954-962, August 2011. ISSN 10.1177/0734242X11413327.

KIM, E. Y.; KIM, M. S.; LEE, J. C.; JEONG, J.; PANDEY, B. D. Leaching Kinetics of Copper from Waste Printed Circuit Boards by Electro-Generated Chlorine in HCl Solution. Hydrometallurgy, Elsevier, v. 107, n. 3-4, p. 124-132, May 2011. ISSN 10.1016/j.hydromet.2011.02.009.

KITCO METALS INC. Gold, Silver, Gold Price, Silver Price, Gold Rate, Gold News, 10 Maio 2015. Disponível em: <www.kitco.com/>. Acesso em: 12 Maio 2015. KLIMACH, H.; FABRIS, E. Eletrônica Fundamental - Notas de Aula. Delet EE - UFRGS. Porto Alegre. 2012. 
LACOR. Notas de Aula - Processos. Laboratório de Corrosão, Proteção e Reciclagem de Materiais - LACOR. Universidade Federal do Rio Grande do Sul UFGRS. Porto Alegre. 2014.

LEE, J.; KIM, Y.; LEE, J.-C. Disassembly and physical separation of electric electronic components layered in printed circuit boards (PCB). Environmental Science and Technology, University of California. Berkeley, 2012.

LEVENSPIEL, O. Chemical Reaction Engineering. 2nd. ed. New York: John Wiley \& Sons, 1972.

LI, J.; ZENG, X. Recycling Printed Circuit Boards. Em: GOODSHIP, V.; STEVELS, A. Waste Electrical and Electronic Equipment (WEEE) Handbook. 1st. ed. UK: Woodhead Publishing, 2012. Cap. 13, p. 287-311.

LI, Y.; KAWASHIMA, N.; LI, J.; CHANDRA, A.P.; GERSON, A.R. A review of the structure, and fundamental mechanisms and kinetics of the leaching of chalcopyrite. Minerals and Materials Science \& Technology, University of South Australia. Adelaide, 2013.

LOUREIRO, B. M.; SILVAS, F. P. C.; MORAES, V. T.; TENÓRIO, J. A. S.; ESPINOSA, D. C. R. Valorização, Classificação e Caracterização de PCls. 69ำ Congresso Anual da ABM - Internacional \& 14ํㅡㄹ ENEMET - Encontro Nacional de Estudantes de Engenharia Metalúrgica, de Materiais e de Minas. São Paulo: ABM. 2014.

LUDA, M. P. Recycling of Printed Circuit Boards - Integrated Waste Management. Dipartimento di Chimica dell' Università di Torino: Intech, v. II, 2011.

LUZ, A. B. D.; LINS, F. A. F. Introdução ao Tratamento de Minérios. Em: DA LUZ, A. B.; SAMPAIO, J. A.; FRANÇA, S. C. A. Tratamento de Minérios. 4a․ ed. Rio de Janeiro: Centro de Tecnologia Mineral CETEM, v. 1, 2004. Cap. 1, p. 3-16.

MASSUCATTO, D.; TENÓRIO, J. A. S.; ESPINOSA, D. C. R. Obsolete Printed Circuit Boards Characterization: Notebook Motherboard and Its Size Fractions. 14th International Waste Management and Landfill Symposium. Santa Margherita di Pula: Proceedings of Sardinia 2013. 2013.

MDIC. Logística Reversa de Equipamentos Eletroeletrônicos - O Resíduo Eletroeletrônico. Ministério do Desenvolvimento da Indústria e Comércio Exterior. Brasília. 2013. 
MELO, P. R. D.; RIOS, E. C. D.; GUTIERREZ, R. M. V. Placas de Circuito Impresso: Mercado Atual e Perspectivas. Banco Nacional de Desenvolvimento Econômico e Social. BNDES Setorial. Rio de Janeiro, p. 113-136. 2001.

METALPRICES. Price Methodology: MetalPrices.com, an Argus Media Service. MetalPrices.com, 2015. Disponível em: <http://www.metalprices.com>. Acesso em: 28 June 2015.

MMA. Plano Nacional de Resíduos Sólidos. Ministério do Meio Ambiente. Brasília. 2012.

MOOKHERJEE, S.; RAY, M. Isothermal Reduction of Iron Ore Fines Surrounded by Coal or Char Fines. Journal of Iron Making, v. V, n. 13, p. 229-235, 1986.

MORAES, V. T. D. Caracterização e Processamento de Telas de Cristal Líquido Visando a Reciclagem. Dissertação de Mestrado. Escola Politécnica da Universidade de São Paulo - EPUSP. São Paulo. 2006.

MORAES, V. T. D. Recuperação de Metais a Partir do Processamento Mecânico e Hidrometalúrgico de Placas de Circuito Impresso de Celulares Obsoletos. Tese de Doutorado. Escola Politécnica da Universidade de São Paulo EPUSP. São Paulo. 2011.

MOURÃO, M. B. Análise do Processo de Redução de Minério de Ferro por Carbono na Forma de Pelotas Auto-Redutoras. Escola Politécnica da Universidade de São Paulo. Tese de Doutorado. São Paulo. 1988.

MUÑOZ, S. I. S. Impacto Ambiental na Área do Aterro Sanitário e Incinerador de Resíduos de Ribeirão Preto-SP: Avaliação dos Níveis de Metais Pesados. Tese de Doutorado. Escola de Enfermagem de Ribeirão Preto da Universidade de São Paulo. Ribeirão Preto. 2002.

NOGUEIRA, S. P. Política Nacional de Resíduos Sólidos. Seminário Nacional de Limpeza Pública, Associação Brasileira de Resíduos Sólidos e Limpeza Pública. São Paulo, 2010.

OFFICIAL JOURNAL OF THE EUROPEAN UNION. Directive 2002/96/EC of the European Parliament and of the Council of 27 January 2003 on the waste electrical and electronic equipment (WEEE). Official Journal of the European Union, v. L37, p. 24, 2003. 
OLIVEIRA, M. L. M. D.; AQUINO, J. A. D. Amostragem. Em: LUZ, A. B. D.; SAMPAIO, J. A.; FRANÇA, S. C. A. Tratamento de Minérios. 5․a ed. Rio de Janeiro: Centro de Tecnologia Mineral - CETEM, v. 1, 2007. Cap. 1, p. 3-34.

OLIVEIRA, P. C. F. D. Valorização de Placas de Circuito Impresso por Hidrometalurgia. Tese de Doutoramento. Instituto Superior Técnico da Universidade Técnica de Lisboa. Lisboa, p. 290. 2012.

ONGONDO, F. O.; WILLIAMS, I. D.; CHERRETT, T. J. How are WEEE doing? A Global Review of the Management of Electrical and Electronic Wastes. Waste Management, Elsevier, v. 31, n. 4, p. 714-730, 2011.

PARK, Y. J.; FRAY, D. J. Recovery of High Purity Precious Metals from Printed Circuit Boards. Journal of Hazardous Materials, v. 164, p. 1152-1158, 2009.

PEIXOTO, G. H. C.; SOBRAL, L. G. S.; OLIVEIRA, D. M. D. Influência do Biossurfatante Ramnolipídeo na Biolixiviação de Minério Primário de Cobre. XVII Jornada de Iniciação Científica. Rio de Janeiro: Centro de Tecnologia Mineral CETEM. 2009.

PETTER, P. M. H.; BERNARDES, A. M.; VEIT, H. M.; BRITO, D. O. Estudo de Lixiviantes Alternativos para Extração de Metais de Placas de Circuito Impresso. VIII Simpósio Internacional de Qualidade Ambiental. Porto Alegre: ABES. 2012.

PETTER, P. M. H.; VEIT, H. M.; BERNARDES, A. M. Evaluation of Gold and Silver Leaching from Printed Circuit Board of Cellphones. Waste Management, v. 34, n. 2, p. 475-482, February 2014.

POPOV, K. I.; DJOKIC, S. S.; GRGUR, B. N. Fundamental Aspects of Electrometallurgy. 1st. ed. New York: Springer US, v. I, 2002.

PORTERO, M. J. M. Características y Usos de los Diagramas de Pourbaix. Ingeniería Química y Nuclear de la Universidad Politecnica de Valencia. Valencia, España, p. 1-9. 2011.

POURBAIX, M. Atlas of Electrochemical Equilibria in Aqueous Solutions. London: Pergamon Press, 1966.

POURBAIX, M.; ZOUBOV, N. D. Iron. Em: POURBAIX, M. Atlas D'Équilibres Électrochimiques. Paris: Gauthier-Villars et Cie., 1963. Cap. 12.1, p. 307-321.

RAMUNNO, F. A. L. Estudo Cinético da Lixiviação de Metais de Placas de Circuito Impresso Obsoletas. Dissertação de Mestrado. Escola Politécnica da Universidade de São Paulo - EPUSP. São Paulo. 2015. 
RESTIVO, T. A. G. Desenvolvimento de Processo de Eletrólise em Meio de Sais Fundidos Para a Produção de Metais de Terras-Raras Leves: a Obtenção do Cério Metálico. Dissertação de Mestrado. Instituto de Pesquisas Energéticas e Nucleares - IPEN. Universidade de São Paulo - USP. São Paulo. 1994.

REUTER, M. A.; BOIN, U. M. J.; VAN SCHAIK, A.; VERHOEF, E. V. Pyrometallurgy: The Key to Sustainable Use of Materials. XXII International Mineral Processing Congress. Cape Town, South Africa: Document Transformation Technologies. 2003. p. 128-149.

RIBEIRO, P. P. M. Concentração de Metais Contidos em Placas de Circuito Impresso de Computadores Descartados. Projeto de Graduação. Escola Politécnica da Universidade Federal do Rio de Janeiro. Rio de Janeiro. 2013.

RIBEIRO, T. F.; LIMA, S. D. C. Coleta Seletiva de Lixo Domiciliar - Estudo de Casos. Caminhos de Geografia, Instituto de Geografia da Universidade Federal de Uberlândia. Uberlândia, 2000.

ROCCHETTI, L.; VEGLIÒ, F.; KOPACEK, B.; BEOLCHINI, F. Environmental Impact Assessment of Hydrometallurgical Processes for Metal Recovery from WEEE Residues Using a Portable Prototype Plant. Environmental Science \& Technology - American Chemical Society, Washington, v. 47, n. 3, p. 1581-1588, January 2013.

ROSALES, V. U.; GUERRERO, J. R.; SÁEZ, M. Biohidrometalurgia en la Recuperación de Valores Metálicos. Industrial Data. Lima, p. 7-10. 2001. (15609146).

ROSARIO, C. G. A.; VeZZÁ, G. M.; SILVAS, F. P. C.; MORAES, V. T.; ESPINOSA, D. C. R.; TENÓRIO, J. A. S. Caracterização de Placa de Circuito Impresso Proveniente de Computadores Obsoletos Visando Processamento Biohidrometalúrgico. 69ำ Congresso Internacional Anual da ABM. São Paulo: Associação Brasileira de Metalurgia e Materiais. 2014.

SAMPAIO, J. A.; FRANÇA, S. C. A.; LUZ, A. B. D. Ensaios de Separação Magnética e Eletrostática. Em: LUZ, A. B. D.; SAMPAIO, J. A.; FRANÇA, S. C. A. Tratamento de Minérios. 5 ${ }^{\text {a }}$ ed. Rio de Janeiro: Centro de Tecnologia Mineral CETEM, v. IV, 2007. Cap. 18, p. 321-348. 
SAMPAIO, J. A.; LUZ, A. B. D. Separação Magnética e Eletrostática. Em: LUZ, A. B. D.; SAMPAIO, J. A.; FRANÇA, S. C. A. Tratamento de Minérios. 4ª ed. Rio de Janeiro: Centro de Tecnologia Mineral - CETEM, v. 1, 2004. Cap. 8, p. 305-338.

SANTANILLA, A. J. M. Recuperação de Níquel a Partir do Licor de Lixiviação de Placas de Circuito Impresso de Telefones Celulares. Dissertação de Mestrado. Escola Politécnica da Universidade de São Paulo - EPUSP. São Paulo. 2012.

SCHLUEP, M.; HAGELUEKEN, C.; KUERHR, R.; MAGALINI, F.; MAURER, C.; MESKERS, C.; MUELLER, E.; WANG, F. Recycling - From e-Waste to Resources. United Nations Environment Programme (UNEP) \& the United Nations University, p. 95, 2009.

SCHMALENSEE, R. Regulation and the Durability of Goods. The Bell Journal of Economics and Management Science, RAND Corporation, v. 1, n. 1, p. 5464, Spring 1970.

SHENG, P. P.; ETSELL, T. H. Recovery of Gold from Computer Circuit Board Scrap Using Aqua Regia. Waste Management \& Research, Internations Solid Waste Association. Thomson Reuters, v. 25, n. 4, p. 380-383, August 2007. ISSN 10.1177/0734242X0707694.

SILVA, A. P. M.; CALDAS, M. P. K.; SOUSA, L. M.; MORAES, V. T.; NASCIMENTO, F. C.; ESPINOSA, D. C. R.; TENÓRIO, J. A. S. Estudo de Rota Hidrometalúrgica Visando Recuperação de Prata a Partir de Resíduos de Placas

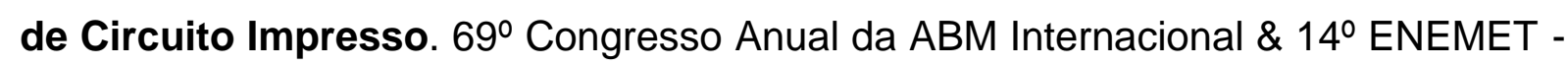
Encontro Nacional de Estudantes de Engenharia Metalúrgica, de Materiais e de Minas. São Paulo: ABM. 2014.

SILVA, M. B. O. Obsolescência Programada e Teoria do Decrescimento Versus Direito ao Desenvolvimento e ao Consumo (Sustentáveis). Veredas do Direito, Belo Horizonte, v. 9, n. 17, p. 181-196, Janeiro-Junho 2012.

SILVAS, F. P. C. Utilização de Hidrometalurgia e Biohidrometalurgia para Reciclagem de Placas de Circuito Impresso. Escola Politécnica da Universidade de São Paulo. Tese de Doutorado. São Paulo. 2014. 
SILVAS, F. P. C.; MORAES, V. T.; BORTOLINI, G. A.; GOMES, O. F. M.; GAYDARDZHIEV, S.; ESPINOSA, D. C. R.; TENÓRIO, J. A. S. Characterization of Printed Circuit Boards from Scrap Printers. TMS - The Minerals, Metals \& Materials Society, EPD Congress, 2014.

SOUZA, C. C. B. M.; OLIVEIRA, D. C.; TENÓRIO, J. A. S. Characterization of Used Alkaline Batteries Powder and Analysis of Zinc Recovery by Acid Leaching. Journal of Power Sources, Elsevier, v. 103, n. 1, p. 120-126, December 2001. ISSN 10.1016/S0378-7753(01)00850-3.

SUTTILL, K. L. Pyromet or Hydromet? Engineering and Mining Journal, New York, v. 191, n. 5, p. 30-35, 1990. ISSN 0095-8948.

SYED, S. A Green Technology for Recovery of Gold from Non-Metallic Secondary Sources. Hydrometallurgy, v. 82, p. 48-53, 2006.

TAKAHASHI, V. C. I. Reciclagem de Baterias de Íons de Lítio: Condicionamento Físico e Extração de Cobalto. Escola Politécnica da Universidade de São Paulo - EPUSP. São Paulo. 2007.

TAKENO, N. Atlas of Eh-pH diagrams: Intercomparison of thermodynamic databases. Geological Survey of Japan Open File Report No.419. National Institute of Advanced Industrial Science and Technology. Research Center for Deep Geological Environments. Japan. 2005.

TAN, Z.; HE, Y.; XIE, W.; DUAN, C.; ZHOU, E.; YU, Z. Size Distribution of Wet Crushed Waste Printed Circuit Boards. Mining Science and Technology, China, v. 21, n. 3, p. 359-363, May 2011.

TSYDENOVA, O.; BENGTSSON, M. Chemical Hazards Associated with Treatment of Waste Electric and Electronic Equipment. Waste Management, v. 31, p. 45-58, 2011.

TUNCUK, A.; STAZI, V.; AKCIL, A.; YAZICI, E. Y.; DEVECI, H. Aqueous Metal Recovery Techniques from E-Scrap: Hydrometallurgy in Recycling. Minerals Engineering, v. 25, n. 1, p. 28-37, January 2012.

UNDESA. Environmentally Sound Management of Solid Wastes and Sewage-Related Issues. Division for Sustainable Development, United Nations Department of Economic and Social Affairs. Agenda 21. Chapter 21. 2005. 
UNEP. Sustainable Innovation and Technology Transfer Industrial Sector Studies. Recycling from E-Waste to Resources, United Nations Environment Programme, v. I, p. 58-65, Julho 2009.

UNEP. Towards a Green Economy: Pathways to Development and Poverty Eradication. United Nations Environment Programme - Environment for Development, 2011. Disponível em: <www.unep.org/greeneconomy/>. Acesso em: 4 Fevereiro 2015. UNEP. Environmental Risks and Challenges of Anthropogenic Metals Flows and Cycles. The United Nations Environmental Programme. Nairobi. 2013.

UNEP. Metal Recycling: Opportunities, Limits, Infrastructure. A Report of the Working Group on the Global Metal Flows to the International. The United Nations Environment Programme. Paris. 2013.

UNITED NATIONS ENVIRONMENT PROGRAMME. E-waste management manual. E-waste, v. II, 2007.

UNITED NATIONS UNIVERSITY. The Step Initiative Annual Report 2011/2012. The United Nations University. Bonn, Germany. 2012.

UNITED NATIONS UNIVERSITY. The Step Initiative Annual Report 2012/2013. The United Nations University. Bonn, Germany. 2013.

USHIZIMA, M. M.; MARINS, F. A. S.; MUNIZ JR., J. Política Nacional de Resíduos Sólidos: Cenário da Legislação Brasileira com Foco nos Resíduos Eletroeletrônicos. XI Simpósio de Excelência em Gestão e Tecnologia: Gestão do Conhecimento para a Sociedade, Universidade Estadual Paulista Júlio de Mesquita Filho - Unesp, 2014.

VEIT, H. M.; BeRnARDES, A. M.; BeRTUOL, D. A.; OliVeIRA, C. T. Utilização de Processos Mecânicos e Eletroquímicos para Reciclagem de Cobre de Sucatas Eletrônicas. REM, Escola de Minas de Ouro Preto. Minas Gerais, p. 159164, 2008.

VEIT, H. M.; PEREIRA, C. D. C.; BERNARDES, A. M. Using Mechanical Processing in Recycling Printed Wiring Boards. The Journal of The Minerals, Metals \& Materials Society (TMS), v. 54, n. 6, p. 45-47, June 2002. ISSN 1543-1851.

VELOSO, Z. M. F. Política Nacional de Resíduos Sólidos - A Responsabilidade do Setor Público Frente à Geração de Resíduos Sólidos. Diretoria de Ambiente Urbano - Secretaria de Recursos Hídricos e Ambiente Urbano. Brasília, p. 45. 2014. 
Venkatraman, P.; KNOLL, F. S.; LAWVER, J. E. Magnetic and Electrostatic Separation. Em: FUERSTENAU, M.; HAN, K. Principles of Mineral Processing. New York: Society for Mining Metallurgy and Exploration - SME, 2006. p. 221-244.

VOGEL, A. I. Vogel's Textbook of Macro and Semimicro Qualitative Inorganic Analysis. 5th. ed. London: Longman Group Limited, 1979. 605 p.

WALDMAN, M. Planned Obsolescence and the R\&D Decision. The Rand Journal of Economics, v. 27, n. 3, p. 583-595, October 1996.

WIDMER, R.; LOMBARD, R. A Report of the Swiss Global e-Waste Programme - Knowledge Partnerships in e-Waste Recycling - e-Waste Assessment in South Africa. St. Gallen, Swizerland: EMPA - Materials Science \& Technology, 2005.

XAVIER, L. H.; SANTOS, M. C. L.; FRADE, N. B.; CARVALHO, T. C. M. B. Aspectos Socioambientais e Técnicos da Gestão de Resíduos de Equipamentos Eletrônicos. São Paulo: Instituto de Energia e Ambiente da Universidade de São Paulo (IEE-USP) \& Centro de Descarte e Reuso de Resíduos de Informática (CEDIR), 2012.

YAMANE, L. H. Recuperação de Metais de Placas de Circuito Impresso de Computadores Obsoletos Através de Processo Biohidrometalúrgico. Tese de Doutorado. Escola Politécnica da Universidade de São Paulo - EPUSP. São Paulo. 2012.

YAMANE, L. H.; MORAES, V. T.; ESPINOSA, D. C. R.; TENÓRIO, J. A. S. Recycling of WEEE: characterization of spent printed circuit boards from mobile phones and computers. Waste Management, v. 31, 2011.

YOO, J.-M.; JEONG, J.; YOO, K.; LEE, J.-C.; KIM, W. Enrichment of the Metallic Components from Waste Printed Circuit Boards by a Mechanical Separation Process Using a Stamp Mill. Waste Management, v. 29, n. 3, p. 11321137, March 2009.

ZHANG, Y.; LIU, S.; XIE, H.; ZENG, X.; LI, J. Current Status on Leaching Precious Metals from Waste Printed Circuit Boards. Procedia Environmental Sciences, v. 16, p. 560-568, January 2012. 
ZUMBUEHL, D. Mass Flow Assessment (MFA) and Assessment of Recycling Strategies for Cathode Ray Tubes (CRTs) for the Cape Metropolitan Area (CMA). South Africa: ETH-EMPA. 2006.

ZURBRUGG, C. Solid Waste Management in Developing Countries Basics of Solid Waste Management. SANDEC-EAWAG, 2003. 